Fabricio Cecanho Furlan

\title{
Micose fungoide hipocromiante: estudo epidemiológico e análise patogenética dos mecanismos da hipopigmentação
}

Tese apresentada à Faculdade de Medicina da Universidade de São Paulo para obtenção do título de Doutor em Ciências

Programa de Dermatologia

Orientador: Prof. Dr. José Antonio Sanches Junior

São Paulo

2013 
Dados Internacionais de Catalogação na Publicação (CIP)

Preparada pela Biblioteca da

Faculdade de Medicina da Universidade de São Paulo

Creprodução autorizada pelo autor

Furlan, Fabricio Cecanho

Micose fungoide hipocromiante : estudo epidemiológico e análise patogenética dos mecanismos da hipopigmentação / Fabricio Cecanho Furlan. -- São Paulo, 2013.

Tese(doutorado)--Faculdade de Medicina da Universidade de São Paulo. Programa de Dermatologia.

Orientador: José Antonio Sanches Junior.

Descritores 1.Micose fungoide 2.Linfoma cutâneo de células T 3.Linfócitos T CD8-positivos 4. Hipopigmentação 5. Melanócitos. 
"If you can't fly then run, if you can't run then walk, if you can't walk then crawl, but whatever you do you have to keep moving forward" (Martin Luther King Jr) 
AGRADECIMENTOS 
Ao Prof. Dr. José Antonio Sanches Junior, meu orientador, pelos ensinamentos, apoio e, sobretudo, confiança. 
À médica patologista Prof. Dra. Mirian Nacagami Sotto, pela contribuição na realização do trabalho.

Ao médico patologista Prof. Dr. Luiz Fernando Ferraz da Silva, pelo auxílio e orientação na execução do projeto.

À bióloga Fernanda Guedes, pelo auxílio técnico.

À aluna do curso de graduação em Medicina da Faculdade de Medicina - USP Bruna Avellar A. Pereira, pela importante contribuição ativa na execução deste trabalho.

Aos funcionários do Laboratório de Anatomia Patológica do departamento de Dermatologia, que contribuíram para execução do trabalho.

Ao Dr. Gustavo Alonso e aos funcionários da Documentação Fotográfica do Ambulatório de Dermatologia do HC-FMUSP, pelo auxílio no registro fotográfico.

À equipe de enfermagem do Ambulatório de Dermatologia do HCFMUSP, pela presteza e atenção a mim dispendida durante a execução do projeto

Aos colegas do Ambulatório de Oncologia Cutânea do Departamento de Dermatologia do HC-FMUSP, pelos anos de ótima convivência.

A Sra. Eli Maria, pela ajuda durante todo o processo da pósgraduação.

À pós-graduação da Universidade de São Paulo pela oportunidade e ao Conselho Nacional de Desenvolvimento Científico e Tecnológico (CNPq) pelo suporte financeiro. 
Esta dissertação ou tese está de acordo com as seguintes normas, em vigor no momento desta publicação:

Referências: adaptado de International Committee of Medical Journals Editors (Vancouver). Universidade de São Paulo. Faculdade de Medicina. Divisão de Biblioteca e Documentação. Guia de apresentação de dissertações, teses e monografias. Elaborado por Anneliese Carneiro da Cunha, Maria Julia de A. L. Freddi, Maria F. Crestana, Marinalva de Souza Aragão, Suely Campos Cardoso, Valéria Vilhena. 3a ed. São Paulo: Divisão de Biblioteca e Documentação; 2011.

Abreviaturas dos títulos dos periódicos de acordo com List of Journals Indexed in Index Medicus. 
SUMÁRIO 


\section{Sumário}

Lista de abreviaturas, símbolos e siglas

Resumo

Summary

1 INTRODUÇÃO

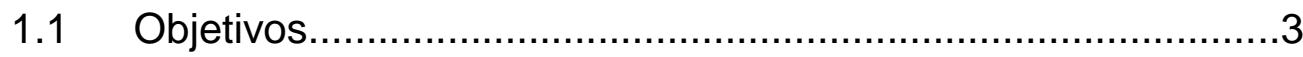

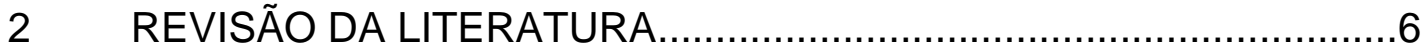

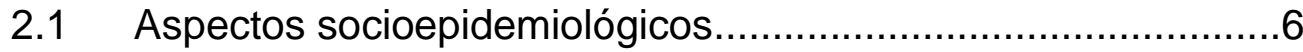

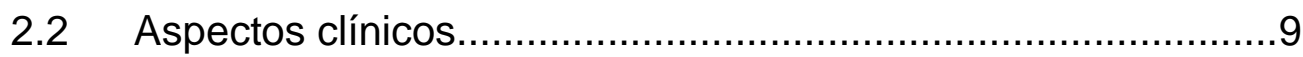

$2.3 \quad$ Aspectos diagnósticos..........................................................11

2.4 Aspectos patogenéticos......................................................

2.4.1 Melanogênese.......................................................14

2.4.2 Patogênese da micose fungoide hipocromiante..........17

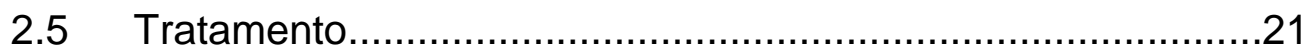

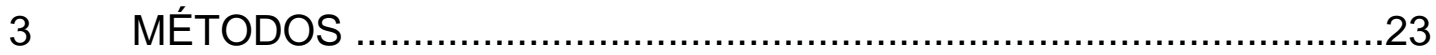

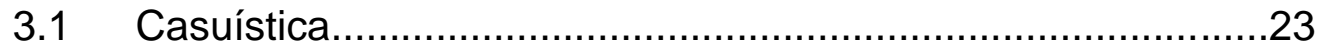

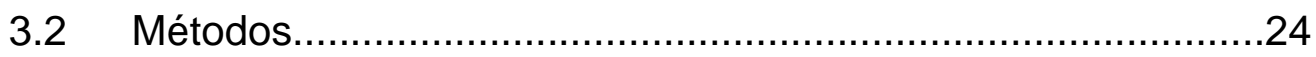

3.2.1 Informações clínicas..................................................24

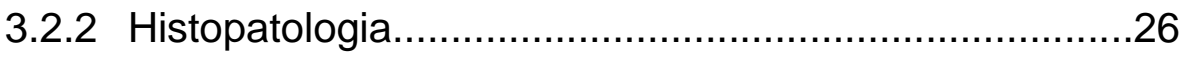

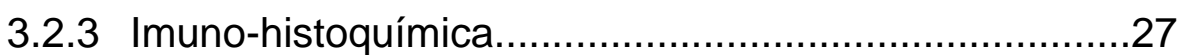

3.3 Análise estatística................................................................

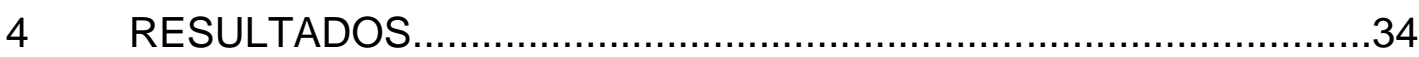

4.1 Aspectos clínicos.................................................................

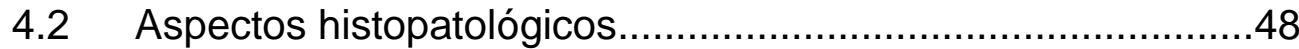

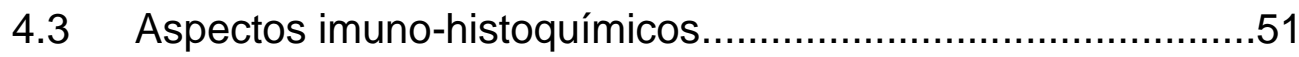


$5 \quad$ DISCUSSÃO

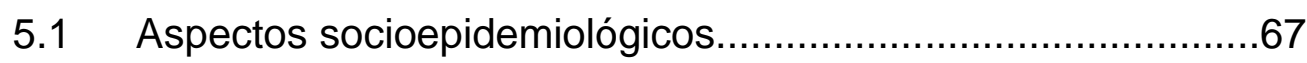

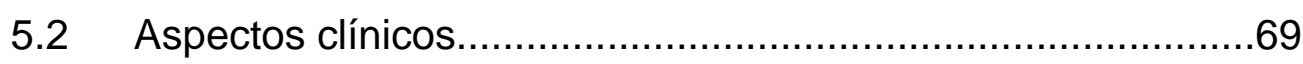

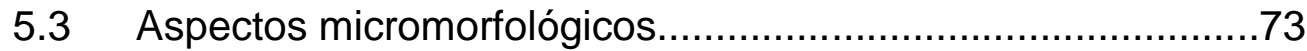

5.4 Aspectos fenotípicos e mecanismos patogenéticos da hipocromia ........................................................................

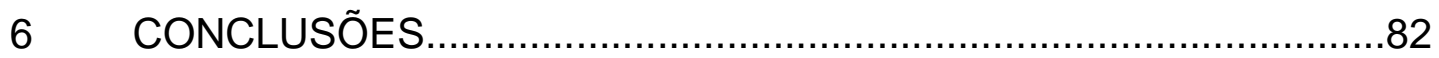

$7 \quad$ ANEXOS

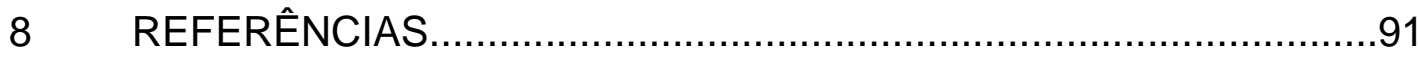




\section{LISTA DE ABREVIATURAS}

$\begin{array}{ll}\text { ACTH } & \text { hormônio adrenocorticotrópico } \\ \text { bFGF } & \text { fator de crescimento fibroblástico básico } \\ \text { CD117 } & \text { receptor melanocítico do SCF (ou c-kit) } \\ \text { Col } & \text { coluna } \\ \text { et al. } & \text { e outros } \\ \text { ET-1 } & \text { endotelina 1 } \\ \text { fig. } & \text { figura }\end{array}$

GM-CSF fator estimulante de colônias de granulócitos e macrófagos

HE hematoxilina-eosina

HGF fator de crescimento do hepatócito

IFNy interferon Gama

LCCT linfoma cutâneos de células T

MC1R receptor melanocítico do a-MSH

MF micose fungoide

MFh micose fungoide hipocromiante

MFm micose fungoide variante mista (presença de lesões hipocrômicas e não-hipocrômicas concomitantes)

MITF fator de transcrição associado à micro-oftalmia

MSH hormônio estimulante de melanócito

NGF fator de crescimento neural

POMC proopiomelanocortina

PUVA fotoquimioterapia (psoraleno + fototerapia com radiação UVA)

SC superfície cutânea

SCF fator de células-tronco

SS síndrome de Sézary

TCLE termo de consentimento livre e esclarecido

TCR receptor de célula $T$ 
TNF- $\alpha \quad$ fator de necrose tumoral alfa

UVB-nb fototerapia com radiação UVB de banda estreita

\section{LISTA DE SÍMBOLOS}

$\begin{array}{ll}\mathrm{cm} & \text { centímetro } \\ \mathrm{mm} & \text { milímetro } \\ > & \text { maior que } \\ < & \text { menor } \\ = & \text { igual a }\end{array}$

\section{LISTA DE SIGLAS}

HCFMUSP Hospital das Clínicas da Faculdade de Medicina da Universidade de São Paulo

ISCL International Society for Cutaneous Lymphomas

USP Universidade de São Paulo 
Resumo

Furlan FC. Micose fungoide hipocromiante: estudo epidemiológico e análise patogenética dos mecanismos da hipopigmentação [tese]. São Paulo: Faculdade de Medicina, Universidade de São Paulo; 2013.

INTRODUÇÃO: A variante hipocromiante da micose fungoide - MF (MFh) apresenta características peculiares, como a predileção por indivíduos jovens e melanodérmicos e curso clínico crônico. Estudos especulam a patogênese da hipocromia comparando-a à do vitiligo. No Brasil, faltam dados que permitam conhecer sua importância na saúde pública. $O$ presente trabalho visou avaliar a epidemiologia, a histopatologia e a imunofenotipagem de uma amostra de pacientes com diagnóstico de MFh e propor hipóteses dos mecanismos patogênicos da hipocromia, além de comparar pacientes portadores de lesões hipocrômicas exclusivas com aqueles portadores de outras formas de MF com lesões hipocrômicas concomitantes. MÉTODOS: Foram selecionados pacientes do Ambulatório de Linfomas Cutâneos do Hospital das Clínicas da Faculdade de Medicina da Universidade de São Paulo e classificados em três grupos: A (21 portadores apenas de lesões hipocrômicas); B (15 portadores de outras formas de MF com lesões hipocrômicas concomitantes) e C (8 pacientes com diagnóstico de MF clássica, estes apenas para avaliações histológica e imuno-histoquímica). Foram obtidos dados clinicoepidemiológicos e realizadas análises histológica e imuno-histoquímica de biópsias das lesões e de pele normal, como controle. Para o estudo imuno-histoquímico foram utilizados os marcadores para imunofenotipagem da neoplasia, Melan-A, tirosinase, SCF, CD117 e MITF. RESULTADOS: Do total de pacientes acompanhados naquele ambulatório, os pacientes com MF portadores de lesões hipocrômicas corresponderam a 16\%. As medianas das idades de início da doença e dos tempos de história foram de, no grupo A 25 anos e 8 
anos; no grupo B, 29 anos e 13 anos, respectivamente; houve predomínio de indivíduos melanodérmicos, acometimento do sexo feminino e a maioria dos pacientes encontrava-se em estágios iniciais da doença em ambos os grupos. A avaliação histológica revelou achados semelhantes, como epidermotropismo de linfócitos atípicos e infiltrado dérmico linfomonocitário nas lesões hipocrômicas e não-hipocrômicas. O imunofenótipo CD8+ do infiltrado neoplásico epidérmico foi mais frequente no grupo $A$, ao passo que os grupos B e $\mathrm{C}$ apresentaram mais casos com imunofenótipo CD4+. A avaliação da função melanocítica das lesões hipocrômicas do grupo $A$ revelou diminuição significativa da imunomarcação dos melanócitos por todos marcadores em comparação à pele normal e às lesões do grupo $\mathrm{C}$. Em relação ao grupo $B$, não houve diferenças para as lesões hipocrômicas, não-hipocrômicas e pele normal, quando avaliadas dentro do próprio grupo (exceto para Melan A). A expressão de SCF pelos queratinócitos foi irregular sobretudo nas lesões hipocrômicas. DISCUSSÃO: Os pacientes com lesões hipocrômicas apresentaram características semelhantes (idade precoce, predomínio do sexo feminino, doença indolente). Mostrou-se que indivíduos melanodérmicos tem maior chance de apresentar lesões hipocrômicas. Além da redução de melanócitos e do receptor melanocítico $\mathrm{CD117}$ em relação à pele normal já demonstradas previamente, mostrou-se, como no vitiligo, a redução da expressão do MITF, fator vital para a função e sobrevida do melanócito. Além disso, também se explicitou desbalanço da produção de citocinas melanogênicas pelos queratinócitos. CONCLUSÃO: A presença de lesões hipocrômicas pode ser considerada um marcador de bom prognóstico na MF. Diferentes mecanismos, como ação celular citotóxica e a alteração do microambiente da unidade epidérmica, colaboram para hipocromia das lesões da MFh.

Descritores: Micose fungoide; Linfoma cutâneo de células T; Linfócitos T CD8-positivos; Hipopigmentação; Melanócitos. 


\section{Abstract}

Furlan FC. Hypopigmented mycosis fungoides: epidemiological study and pathogenetical analysis of hypopigmentation mechanisms [thesis]. São Paulo: Faculdade de Medicina, Universidade de São Paulo; 2013.

INTRODUCTION: The hypopigmented variant of mycosis fungoides MF - (MFh) presents specific characteristics, such as a predilection for young and melanodermic individuals, and chronic clinical course. Studies speculate the pathogenesis of the hypopigmentation comparing it to vitiligo's. In Brazil, the lack of data prevents the knowledge of its importance in public health. This study aimed to evaluate the epidemiology, the histopathology and the immunophenotyping of a sample of patients diagnosed with MFh and to propose hypotheses of the pathogenic mechanisms of hypopigmentation, in addition to comparing exclusive hypopigmented lesion-bearer patients with those bearing other types of MF with concomitant hypopigmented lesions. METHODS: Patients were selected from the Cutaneous Lymphoma Clinic, from Hospital das Clínicas, Faculdade de Medicina, Universidade de São Paulo and classified in three groups: A (21 hypopigmented only lesionbearers); B (15 bearers of other types of MF with concomitant hypopigmented lesion) and C (8 patients diagnosed with classical MF, being those only for histology and immunohistochemistry evaluations). Clinicalepidemiological data were obtained and histology and immunohistochemistry analyses of lesion biopsies and normal skin, as a control, were made. For the immunohistochemistry study, the markers for immunophenotyping the neoplasm, Melan-A, tyrosinase, SCF, CD117 and MITF were used. RESULTS: Of the total number of patients treated at that clinic, the MF patients bearing hypopigmented lesions were $16 \%$. The medians of the age of disease onset and the medical history time were 25 years and 8 years in group $A ; 29$ years and 13 years in group $B$, respectively; there were a 
predominance of melanodermic individuals, involvement of the female sex, and the majority of the patients were in early stages of the disease in both groups. The histological evaluation revealed similar findings, such as epidermotropism of atypical lymphocytes and lympho-monocytic dermal infiltrate in hypopigmented and non-hypopigmented lesions. The CD8+ immunophenotype of the epidermal neoplastic infiltrate was more frequent in group A, while groups $B$ and $C$ showed more cases of CD4+ immunophenotype. The evaluation of the melanocytic function of the hypopigmented lesions in group A revealed a significant decrease of immunostaining of the melanocytes by all markers when compared to normal skin and group $\mathrm{C}$ lesions. Regarding group $\mathrm{B}$, there were no differences to hypopigmented and non-hypopigmented lesions and normal skin, when evaluated within the group itself (except for Melan A). The SCF expression by the keratinocytes was irregular especially in hypopigmented lesions. DISCUSSION: Patients with hypopigmented lesions showed similar characteristics (early age, female sex predominance, indolent disease). It has been showed that melanodermic subjects are more likely to have hypopigmented lesions. In addition to the previously-showed reduction of melanocytes and CD117 melanocytic receptor related to normal skin, it has been showed, as in vitiligo, the reduction of MITF expression, a vital factor for the function and survival of the melanocyte. Besides that, it has been also made explicit a production imbalance of melanogenic cytokines by the keratinocytes. CONCLUSION: The presence of hypopigmented lesions can be considered a marker of good prognosis in MF. Different mechanisms, such as cytotoxic cellular action and the change of the microenvironment of the epidermal unit, collaborate for the hypopigmentation of the lesions of MFh.

Descriptors: Mycosis fungoides; Limphoma, T cell, cutaneous; CD8positive T-lymphocytes; Hypopigmentation; Melanocytes 
INTRODUÇÃO 
INTRODUÇÃO

A micose fungoide (MF) é o linfoma cutâneo de células T (LCCT) primário mais comum. ${ }^{1-3}$ É descrito na forma clássica constituindo-se de lesões não infiltradas "patches", que evoluem para placas e tumores.

Diversas formas clinicopatológicas distintas de MF têm sido descritas, tais como eritrodérmica, granulomatosa, pustulosa, purpúrica, hiperqueratósica e verrucosa, bolhosa, invisível e hipocrômica. ${ }^{4-11}$ Zackheim e McCalmont enumeraram 25 doenças que a MF pode mimetizar, cunhandoa como a grande imitadora dos dias de hoje (posição anteriormente reservado à sífilis). ${ }^{12}$

A hipocromia na MF foi anteriormente associada a formas clínicas bem definidas, como MF poiquilodérmica ou resultante do tratamento. ${ }^{13} \mathrm{O}$ primeiro caso de manifestação hipopigmentada primária da MF foi descrita por Ryan et al. ${ }^{11}$ em 1973. Hoje a forma hipocromiante da MF (MFh), com lesões hipocrômicas ou até mesmo acrômicas, é considerada um subtipo peculiar dentro da MF, uma vez que apresenta algumas características que a diferem da forma clássica. Ela já foi alvo de inúmeras publicações; contudo a raridade da doença faz com que a maioria destas seja constituída de relatos de casos ou séries, faltando estudos mais robustos, que se proponham a discutir sua fisiopatogênese ou tragam casuísticas mais consideráveis. ${ }^{13-21}$ Nos últimos anos, conforme se tem ampliado o 
conhecimento coletivo acerca desta doença, percebemos uma crescente (embora com limitações) presença deste tema como alvo de investigação. Por outro lado, se considerarmos o cenário nacional, há apenas poucos relatos de caso publicados, faltando dados que permitam conhecer a frequência da MFh e, por conseguinte, sua importância na saúde pública brasileira. $^{14-16}$

O desconhecimento sobre esta doença pode ser refletido na aparente falta de critérios na definição de um caso típico de MFh: frequentemente, pacientes com outros subtipos de MF com concomitância de lesões hipocrômicas (formas mistas de MFh) são diagnosticados e relatados em publicações como se portadores de lesões hipocrômicas exclusivas de MFh. ${ }^{17-19}$

\subsection{OBJETIVOS}

O presente trabalho visou, através de uma amostragem de pacientes com MF do Ambulatório de Oncologia Cutânea da Divisão de Dermatologia do Hospital das Clínicas da Faculdade de Medicina da Universidade de São Paulo (HCFMUSP), estabelecer um estudo sobre a MFh, com os seguintes objetivos: 
-Principais:

1. Propor possíveis mecanismos da despigmentação das lesões na MFh e das lesões hipocrômicas dos pacientes com formas mistas de MFh;

2. Avaliar se os mecanismos de despigmentação seriam dependentes ou não do quadro clínico (presença de lesões hipocrômicas exclusivas ou quadros mistos) e do imunofenótipo dos linfócitos neoplásicos (CD4 ou CD8).

-Secundários:

3. Avaliar os aspectos epidemiológicos da MFh de uma amostra de pacientes brasileiros, comparando-os às referências presentes na literatura mundial;

4. Avaliar os aspectos clinicoepidemiológicos dos pacientes com diagnóstico de MFh e os aspectos histopatológicos e imunofenotípicos das lesões cutâneas dos mesmos, e compará-los entre um grupo de pacientes com lesões exclusivamente hipocrômicas e outro com lesões hipocrômicas e não-hipocrômicas concomitantes. 
REVISÃO DA LITERATURA 
2. REVISÃO DA LITERATURA

\subsection{ASPECTOS SOCIOEPIDEMIOLÓGICOS}

Ao contrário da MF clássica, que é tida como doença da sexta década de vida $[3,17]$, a maioria dos pacientes com MFh tem idade muito inferior, sendo comuns relatos de casos na população pediátrica. ${ }^{3,17,20,21}$ Estudos mostram que a variante MFh chega a contribuir com 17 a $59 \%$ de todos os casos de MF na infância. ${ }^{22,} 23$ Tan et al. ${ }^{24}$, em 2006, quando analisaram todos os casos novos de MF/Síndrome de Sézary (SS) de Cingapura no período de 2000 a 2004 encontraram uma idade média de 44,6 anos; contudo, dos 131 pacientes analisados, 47 apresentavam MFh, o que contribuiu para diminuir a média de idade da MF/SS globalmente, uma vez que naqueles a média de idade foi de 21,6 anos. Alsaleh et al. ${ }^{25}$, em 2010, avaliando uma base de 193 pacientes com MF (que representavam 100\% da população do Kuwait), encontraram 77 pacientes com máculas hipocrômicas isoladas ou em combinação com outras formas de lesões. 43 pacientes (ou $22 \%$ da amostra) apresentavam a variante hipocromiante pura, cuja idade ao diagnóstico $(27,6 \pm 12,42$ anos) era inferior à verificada nas demais variantes $(38,14 \pm 14,37$ anos $)$. 
A MFh apresenta clara predileção por pacientes de fototipos altos (classificação de Fitzpatrick). Embora a MF clássica também apresente nos Estados Unidos uma predominância em negros, quando analisamos a MFh encontramos uma maior taxa de acometimento destes, embora a forma clássica continue a ser a principal forma de manifestação da MF nestas populações. $^{3,21,26-28} \mathrm{O}$ acometimento de asiáticos também é muito relatado, ao contrário do que acontece na forma clássica. ${ }^{3,29-31}$ Esta predisposição por indivíduos de fototipos mais altos e asiáticos também pode ser constatada através dos estudos que se propuseram a avaliar uma base de pacientes circunscritos a um espaço definido (seja um centro, hospital, cidade ou mesmo país). Os estudos referidos anteriormente (Tan et al. ${ }^{24}, 2006$ e Alsaleh et al. ${ }^{25}$, 2010) apontaram importante contribuição da manifestação hipopigmentada da MF na Cingapura e Kuwait, respectivamente, assim como AlGhamdi et al. ${ }^{32}$ que, em 2012, mostraram 41,8\% de pacientes com MFh num universo de 43 pacientes com diagnóstico de MF na Arábia Saudita; Jang et al. $^{33}$, em artigo de revisão sobre linfomas cutâneos na população asiática, de 2012, descrevem a variante hipocromiante mais prevalente neste continente que no Ocidente. Poucos são os pacientes de origem caucasiana portadores de MFh relatados na literatura. Ardigó et al. ${ }^{19}$, em 2003, descreveram que pacientes caucasianos, quando apresentam lesões hipocromiantes, estas estão comumente em associação com outras variantes de lesões de MF (eritemato-descamativas, hipercrômicas, poiquilodérmicas). 
Embora se admita que não haja predileção por gênero na MFh, alguns autores, como Shabrawi-Caelen et al. ${ }^{34}$ observaram um evidente predomínio no sexo feminino, num estudo que envolveu 11 mulheres e apenas 4 homens..$^{21,24}$

A incidência da MFh é desconhecida; contudo há consenso de que ela é subestimada. Estudos referidos anteriormente (Tan et al. ${ }^{24}, 2006$, Alsaleh et al. ${ }^{25}, 2010$ e AlGhamdi et al. ${ }^{32}$, 2012) permitiram conhecer sua elevada prevalência dentre os pacientes com diagnóstico de MF em países asiáticos. O longo período entre o início das manifestações da doença e o diagnóstico definitivo é prova de que ocorre comumente seu subdiagnóstico. Na maioria dos casos os quadros diferenciais (vitiligo, pitiríase alba, hanseníase indeterminada, hipocromia pós-inflamatória, além de outros) são considerados como primeiro diagnóstico, até serem excluídos com o decorrer da doença e a falta de resposta desta aos tratamentos empregados. Os relatos escassos sobre a MFh também a faz pouco conhecida por muitos profissionais, impedindo assim o correto diagnóstico. 


\section{$2.2 \quad$ ASPECTOS CLÍNICOS}

O quadro clínico da MFh é caracterizado por máculas e "patches" hipocrômicos ou acrômicos, algumas vezes com aspecto vitiligoide, distribuídos principalmente no tronco e nas porções proximais das extremidades, sobretudo região glútea. ${ }^{29,}{ }^{35}$ Variações da localização podem acontecer, com acometimento das extremidades, cabeça e pescoço. ${ }^{30,} 31$ Outros achados incluem lesões com atrofia e telangectasias, e lesões que se tornam mais evidentes após a exposição solar. ${ }^{26,}{ }^{36}$ Recentemente, Uhlenhake e Mehregan descreveram um caso de uma paciente que apresentava MFh com lesões hipocrômicas no formato de anel. ${ }^{37} \mathrm{O}$ tamanho também não é constante, com descrições de máculas em gotas a placas grandes. ${ }^{18}$ Podem ocorrer casos com lesões únicas. ${ }^{38,} 39$ Os pacientes podem se queixar de prurido nas lesões, que pode variar de intensidade; a sensibilidade está sempre preservada. ${ }^{17,40,41}$ A concomitância de outras variantes morfológicas de lesões de MF (lesões eritematosas, poiquilodérmicas, purpúricas) também é amplamente descrita, e muitas vezes o paciente recebe diagnóstico de MFh, desconsiderando-se assim a padrão misto da doença. ${ }^{17-19,42}$

O diagnóstico diferencial deve englobar dermatite atópica, pitiríase alba, hanseníase, vitiligo, hipocromia pós-inflamatória, sarcoidose, pitiríase liquenóide crônica, pitiríase versicolor, sífilis e outras treponematoses, parapsoríase, líquen escleroso, hipomelanose de lto, nevo-halo, 
hipomelanose macular progressiva e oncocercose. ${ }^{17,18,20,34}$ Indubitavelmente, nas regiões em que a hanseníase é doença endêmica, a MFh pode ser facilmente confundida com esta micobacteriose. Khopkar et al. ${ }^{43}$ descrevaram em 2011 alguns pacientes que haviam recebido poliquimioterapia previamente ao correto diagnóstico de MFh. Recentemente, El-Darouti et al. $^{44}$ descreveram uma nova variante morfológica de parapsoríase, a "parapsoríase hipopigmentada em placas" que certamente deve ser considerada um dos principais diagnósticos da MFh. Além da hipocromia, os pacientes apresentam quadro clínico semelhante à parapsoríase clássica, com lesões digitiformes no tronco, membros inferiores e membros superiores proximais. Os mesmos autores descrevem evolução para MFh em alguns pacientes.

O prognóstico da MFh é considerado excelente, ao menos se comparado com o da MF clássica/ SS: a maioria dos casos exibe exclusivamente lesões em suas fases iniciais, quando ainda não há infiltração. ${ }^{26,27}$ Esta apresentação tende a perdurar por muitos anos, dado a evolução arrastada da MFh, não evoluindo além do estágio IB (placas e patches $>10 \%$ da superfície cutânea (SC) e ausência de acometimento linfonodal e visceral - ISCL'); a variante hipocromiante parece conferir melhor prognóstico que a MF clássica na infância. ${ }^{45}$ Contudo, os mesmos autores que referem melhor prognóstico da MFh também já descreveram óbitos decorrentes da doença. ${ }^{19,20}$ Portanto, apesar do bom prognóstico, a MFh deve sempre ser considerada uma doença neoplásica maligna, e sua

\footnotetext{
* International Society for Cutaneous Linfomas
} 
potencial letalidade não deve ser subestimada. Assim, a avaliação clínica dos portadores desta doença se faz necessária, associada ao completo estadiamento (contagens celulares do sangue periférico, quantificação de células de Sézary e linfócitos $T$ por citometria de fluxo, exame físico dos linfonodos periféricos e biópsia se aumentados além de $1,5 \mathrm{~cm}$ de diâmetro, além de exames de imagem para se descartar o acometimento visceral). Talvez a característica mais marcante desta doença seja seu padrão recidivante, que pode acontecer mesmo até anos após a cura clínicohistopatológica. ${ }^{30}$

\subsection{ASPECTOS DIAGNÓSTICOS}

O diagnóstico é feito através da correlação clinicopatológica. ${ }^{35}$ Por vezes o estudo histopatológico não é conclusivo e o paciente deve permanecer em acompanhamento com o potencial diagnóstico de MFh, com novas biópsias seriadas. A avaliação imuno-histoquímica é uma importante ferramenta complementar, uma vez que o imunofenótipo CD8+ é característico da MFh. ${ }^{19}$ Análise ultraestrutural (microscopia eletrônica) e técnicas de biologia molecular podem ser úteis, porém nem sempre disponíveis na prática clínica. 
Werner et al. ${ }^{35}$, em 2005, avaliando 106 casos de MFh reportados em 33 publicações, definiram critérios histopatológicos que permitem o correto diagnóstico da MFh: paraqueratose focal, número variável de linfócitos em todas as camadas da epiderme, dispostos isolados ou em pequenas coleções; ausência ou discreta espongiose; infiltrado linfocitário em faixa na derme superior. Fato muito relatado é o intenso epidermotropismo, com linfócitos grandes e atípicos, com núcleos convolutos, contrastando com infiltrado dérmico linfocítico discreto a moderado ${ }^{13}$ 17, 26; o mesmo não é encontrado rotineiramente nas lesões iniciais correspondentes da MF clássica. ${ }^{21}$ El Shabrawi-Caelen et al. ${ }^{34}$ enumeraram outros achados possíveis, tais como disqueratose, espongiose discreta, alterações da junção dermoepidérmica simulando dermatite de interface, foliculotropismo e incontinência pigmentar com melanófagos na derme papilar.

O exame imuno-histoquímico também tem mostrado peculiaridades que permitem diferenciar a forma hipocromiante da clássica. $O$ epidermotropismo na MF clássica é de células T CD4+ neoplásicas, ao passo que células T CD8+ representam uma minoria de linfócitos T reativos, residindo predominantemente nas papilas dérmicas; são raros os casos que apresentam células CD8+ epidermotrópicas. ${ }^{34}$ Contudo, na MFh, diversos trabalhos têm mostrado epidermotropismo predominantemente por células $T$ CD8+. ${ }^{17,19,22,34,45,47}$ Outros trabalhos confirmaram as alterações típicas da forma clássica na forma hipocromiante, como predomínio de células T CD4+ e relação CD4:CD8 preservada. ${ }^{21} \mathrm{O}$ predomínio de células $\mathrm{T} C D 8+$ teria importante papel na patogênese da lesão da MFh, uma vez que os linfócitos 
supressores parecem limitar o processo de disseminação dos linfomas cutâneos e poderiam desempenhar um papel imunorregulador e supressor sobre a doença, impedindo o estabelecimento de um estágio mais agressivo, mesmo sendo estas as células neoplásicas. ${ }^{20,48}$.

Poucos trabalhos realizaram pesquisa do rearranjo gênico do receptor de célula T (TCR); El Shabrawi-Caelen et al. ${ }^{34}$, que apresentaram a maior série de casos estudados, demonstraram rearranjo gênico do TCR em seis de 13 pacientes; destes seis, cinco apresentaram rearranjo gênico nos linfócitos intraepidérmicos. Estes dados permitiram inferir que a maioria dos casos de MFh eram derivados de células T CD8+ neoplásicas. Outros autores não encontraram rearranjo gênico do TCR e atribuíram sua ausência à precocidade da lesão e/ou à benignidade da doença. ${ }^{21,26,49}$ Entretanto, faltam séries maiores para conclusões adequadas. 


\subsection{ASPECTOS PATOGENÉTICOS}

\subsubsection{MELANOGÊNESE}

A produção da melanina é um processo complexo, e que ainda não está totalmente elucidada. A melanina é sintetizada pelo melanócito, célula derivada da crista neural. A quantidade de melanócitos varia em função da área considerada, existindo cerca de $2.900 / \mathrm{mm}^{2}$ na pele da cabeça a 1100/mm² na porção superior dos braços. A quantidade de melanócitos não varia em relação às raças; assim, as diferenças dependem da capacidade funcional dos melanócitos. ${ }^{50}$

A melanina é constituída dentro de organelas intracelulares altamente especializadas, os melanossomos. ${ }^{51}$ Estas estruturas contém as diversas enzimas que atuam na formação da melanina, sendo a tirosinase a principal. Em conjunto, a tirosinase, a tirosina hidroxilase isoforma I e a fenilalanina hidroxilase correspondem ao passo essencial para iniciar a melanogênese, e deste modo fazem parte da "teoria das três enzimas". ${ }^{52}$

Existem dois diferentes tipos de melanina: a eumelanina, negra a acastanhada, e a feomelanina, amarela a vermelho-acastanhada. Elas são quimicamente distintas, e diferem também na resposta à radiação ultravioleta: eumelanina tem ação antioxidante fotoprotetora, enquanto que a feomelanina é pró-oxidante fototóxica. ${ }^{53,}{ }^{54}$ Diferentes proporções de 
eumelanina e feomelanina compõem a melanina "natural", presente no interior das células.

Uma vez produzida, a melanina é transferida aos queratinócitos vizinhos; o conjunto de melanócito com os queratinócitos adjacentes (cerca de 36) correspondem ao termo "unidade epidérmica". Esta relação é constante. O resultado final deste processo é uma capa de melanina supranuclear, que cobre e protege o material genético do queratinócito da ação deletéria da radiação ultravioleta. ${ }^{55}$

A melanogênese é influenciada por diversos fatores, tanto melanocíticos como os presentes no microambiente da unidade epidérmica.

Ao longo da década de 90 um novo fator de transcrição foi identificado; sua inativação resultava em camundongos brancos com micro-oftalmia. A perda da pigmentação era decorrente da ausência de melanócitos. Assim, esse fator transcricional foi chamado de "Fator de Transcrição Associado à Micro-oftalmia" (Microphthalmia-associated Transcription Factor - MITF). ${ }^{56,57}$ O MITF, tendo mais de 40 genes-alvo, é capaz de controlar o crescimento, sobrevida e diferenciação do melanócito, além da melanogênese. Esta ação do MITF sobre a melanogênese se faz pela regulação da expressão de diversas enzimas, como a tirosinase. Além do controle direto sobre a síntese de melanina, o MITF também interfere nas proteínas estruturais do melanossomo e do transporte da melanina. Por sua vez, a regulação da sobrevida do melanócito é determinada pela ação do MITF sobre genes antiapoptóticos (Bcl2, Kit e Ngfr) e proteínas (BIRC7). ${ }^{58}$ 
As citocinas produzidas pelos queratinócitos também são determinantes sobre o melanócito, ao afetarem sua migração, proliferação e diferenciação. Fatores derivados dos queratinócitos e já identificados com ação sobre o melanócito incluem o Fator de Crescimento Fibroblástico Básico (bFGF), Fator de Células-Tronco (SCF), o Fator de Crescimento do Hepatócito (HGF), o Fator Estimulante de Colônias de Granulócitos e Macrófagos (GM-CSF), Fator de Crescimento Neural (NGF), Hormônio Estimulante de Melanócito (MSH), Hormônio Adrenocorticotrópico (ACTH), endotelinas (como a Endotelina 1 - ET-1) endorfinas, prostraglandinas, além de outros. ${ }^{59}$

Um exemplo desta interação queratinócito-melanócito é a "cascata de bronzeamento": a exposição da pele à radiação ultravioleta determina a ativação da expressão do p53 no queratinócito. Através da ligação do p53 com o promotor da proopiomelanocortina (POMC), há produção do $\alpha-\mathrm{MSH}$; este, por sua vez, liga-se ao seu receptor melanocítico, o MC1R, que ativa a via do AMP cíclico. Um dos alvos desta via é justamente o MITF, que levará à ativação da transcrição dos genes das enzimas da melanogênese, e por conseqüência, a produção de melanina ${ }^{60}$

Umas das citocinas secretadas pelo queratinócito é o SCF, cujo receptor no melanócito é o CD117 (ou c-kit). A interação SCF/CD117 exerce ação regulatória sobre a expressão do MITF: em resposta ao sinal desencadeado pela ligação SCF/CD117, o MITF é fosforilado e translocado para o núcleo do melanócito, para ativar a transcrição de vários genes, como o da tirosinase.$^{61}$ Juntamente com a endotelina, o SCF desempenha um 
importante papel na manutenção e ativação da função melanocítica, conduzindo para uma pigmentação normal a acentuada.$^{62}$

\subsubsection{PATOGÊNESE DA MICOSE FUNGOIDE HIPOCROMIANTE}

Inicialmente, em 1982, Breathnach et al. $^{63}$, por meio de análise da ultraestrutura através da microscopia eletrônica, propuseram que as células atípicas neoplásicas causariam degeneração dos melanócitos e melanogênese anormal; como nenhuma evidência do bloqueio da transferência de melanossomas foi encontrada, concluiu-se que as alterações eram uma resposta inespecífica da lesão celular associada à inflamação. ${ }^{63}$ Por sua vez, Goldberg et al. ${ }^{64}$, também por microscopia eletrônica, demonstraram número reduzido de melanossomas dentro dos queratinócitos, a despeito de encontrarem melanossomas abundantes e morfologicamente normais nos melanócitos adjacentes. Também não evidenciaram alterações degenerativas nos melanócitos. Após tratamento dos pacientes relatados com mostarda nitrogenada tópica, houve repigmentação e a microscopia eletrônica da área tratada revelou numerosos melanossomas, de aspecto normal, dentro dos queratinócitos. Assim, concluiu que na MFh poderia haver um defeito na transferência de melanossomas dos melanócitos para os queratinócitos, com reversão deste defeito após o tratamento. ${ }^{64}$ Diversos outros trabalhos demonstraram ora 
redução do número e alteração da morfologia de melanócitos, ora defeito da transferência dos melanossomas. ${ }^{17,} 20,26,65$ Contudo, é possível que essas duas hipóteses sejam válidas, com diferentes espectros de acometimento da melanogênese, sendo a morte das células pigmentadas sua expressão extrema. $^{21}$

O predomínio de linfócitos T CD8+ no infiltrado neoplásico das lesões cutâneas pode validar a hipótese de que a hipocromia se deve ao efeito citotóxico desses linfócitos supressores sobre os melanócitos. O que é incerto é se linfócitos CD8 não-neoplásicos reativos poderiam desempenhar papel semelhante nas lesões em que ocorre o predomínio de células $T$ CD4+. ${ }^{19,29,66}$ Assim, linfócitos neoplásicos e não-neoplásicos seriam capazes de inibir, ou mesmo destruir os melanócitos da pele afetada, levando a formação de lesões hipocrômicas.

Nas placas iniciais e "patches" de MF predomina resposta imune Th1, com importante participação de interferon gama (IFNY) e células T CD8+. Com a evolução para placas infiltradas e tumores, demonstra-se predomínio da resposta Th2. Assim, a resposta Th1 é tida como uma forma de defesa do organismo contra a neoplasia e quando há alteração do padrão de defesa (Th1 para Th2), a evolução é de pior prognóstico. ${ }^{67}$ Poderíamos transpor esses conceitos para a MFh.

A hipocromia poderia representar o resultado extremo de uma resposta imune protetora. Nos casos em que predominam células T CD8+, o infiltrado 
celular garantiria uma doença indolente, de bom prognóstico, impedindo a transformação para resposta Th2 e evolução da neoplasia.

Estudos que fizeram um paralelo entre os mecanismos de hipopigmentação do vitiligo e da MFh dão importante contribuição para o entendimento de sua patogênese. ${ }^{47}$.

Moretti et al demonstraram uma alteração significante das citocinas epidérmicas existentes nas lesões de vitiligo, nas quais não havia nenhum melanócito presente. Nestas lesões, as citocinas de atividade estimulatória sobre os melanócitos (GM-CSF, SCF e bFGF) estavam reduzidas, enquanto que as citocinas de ação inibitória interleucina 6 (IL-6) e fator de necrose tumoral alfa (TNF- $\alpha$ ) estavam significativamente aumentadas. Estes resultados parecem confirmar, pelo menos em parte, a inibição da melanogênese in vitro induzida pelo TNF- $\alpha$, através de uma ação inibitória sobre a tirosinase e a proteína relacionada à tirosinase 1 , ambas essenciais para a síntese da melanina ${ }^{68} \mathrm{Em}$ acordo com estes achados, recentemente, Seif El Nasr et al. ${ }^{69}$ mostraram aumento dos níveis de TNF- a e redução da expressão de mRNA codificador de bFGF em lesões de MFh, vitiligo e pitiríase versicolor.

Singh et al. ${ }^{22}$ demonstraram que no vitiligo há diminuição da expressão do receptor CD117 nos melanócitos epidérmicos, aumentando a chance de apoptose destas células. Na lesão de vitiligo também há um predomínio de células T CD8+ no infiltrado epidérmico. Estas mesmas alterações foram encontradas na MFh, porém o que não se repetiu na MF clássica nem na 
pele normal. Assim, propôs que na lesão da MFh os efeitos citotóxicos das células T CD8+ provocariam diminuição da expressão do CD117 nos melanócitos, culminando na disfunção e/ou perda destas células. Já Kitamura et al. ${ }^{61}$ demonstraram que nas bordas das lesões de vitiligo há aumento da secreção de ET-1 e SCF pelos queratinócitos, ao passo que nos melanócitos há diminuição acentuada do CD117 e do MITF, sem alteração da expressão do receptor da ET-1. Deste modo, a diminuição do CD117 e do MITF estariam associadas à predisposição elevada para apoptose dos melanócitos; além disso, o CD117 serviria para manter os melanócitos dentro da epiderme, através da atração pelo SCF.

Alikhan et al. ${ }^{70}$ estudaram as alterações da imunidade celular no vitiligo: até mesmo amostras de pele perilesional com aparência normal já demonstravam alguns achados histológicos, como degeneração dos melanócitos, vacuolização da camada basal, infiltrado linfocitário e melanófagos na derme superior. As células $\mathrm{T}$ epidermotrópicas apresentavam uma relação CD8/CD4 aumentada e muitas delas expressavam CD25, complexo de histocompatibilidade II (especificamente o HLA-DR) e secretavam IFN- $\gamma$.

Em suma, a resposta Th1, sobretudo através das células CD8+, sejam elas neoplásicas ou reativas, e de suas citocinas características (TNF- $\alpha$ e IFN-y), além de impedirem a evolução da MF para placas e tumores, também levariam à inibição da melanogênese. Deste modo, a hipocromia seria um marcador de bom prognóstico da MF. 


\section{$2.5 \quad$ TRATAMENTO}

Fototerapia é o método mais empregado, sobretudo a fotoquimioterapia (PUVA terapia); esta possibilita rápida e completa remissão na maioria dos casos e pode ser indicada como tratamento de primeira escolha. ${ }^{3,13,31}$ UVB narrow band (UVB-nb) também tem sido muito utilizado, sobretudo em crianças; embora baixas taxas de resposta tenham sido descritas em indivíduos de fototipos altos, possivelmente pelo efeito fotoprotetor da melanina, alguns autores têm descrito sua eficácia na população asiática. ${ }^{36,}$ 71, 72 Contudo, nesta etnia ainda a PUVA terapia apresenta melhores resultados. ${ }^{73}$ Outras opções terapêuticas efetivas descritas são mostarda nitrogenada tópica, carmustina tópica e irradiação total da pele com elétrons (banho de elétrons). ${ }^{13}$ Importante salientar que a MFh, na maioria dos casos, representa doença benigna e altamente recidivante, o que contraindica tratamentos agressivos e intempestivos. Sendo a recidiva comum, que pode acontecer de poucos meses a vários anos após a remissão, o acompanhamento se faz obrigatório. ${ }^{30,43}$ 
MÉTODOS 


\section{MÉTODOS}

\subsection{CASUÍSTICA}

Trata-se de um estudo observacional prospectivo. Foi realizado levantamento de todos os pacientes acompanhados no Ambulatório de Oncologia Cutânea - Linfomas Cutâneos da Divisão de Clínica Dermatológica do HCFMUSP, no período de fevereiro de 2009 a outubro de 2011, durante as consultas de rotina. Dentre estes foram selecionados pacientes portadores de MF com diagnóstico confirmado pela correlação clínico-patológica e portanto, possuidores de exame histopatológico prévio realizado durante as consultas ambulatoriais. Os pacientes foram separados em três grupos distintos, de acordo com as manifestações cutâneas da doença apresentada. O grupo A foi composto por pacientes portadores exclusivamente de lesões hipocrômicas; o grupo B constituiu-se de pacientes com diagnóstico de MF apresentando quadro clínico misto, com lesões hipocrômicas e não-hipocrômicas; o grupo C, formado para comparação histopatológica e imunofenotípica, foi composto por pacientes portadores de MF sem lesões hipocrômicas.

Após leitura e assinatura do Termo de Consentimento Livre e Esclarecido (TCLE), foi preenchido um protocolo para coleta de dados sócio- 
demográficos e clínicos, que auxiliou na divisão dos pacientes nos grupos já mencionados. Os pacientes também foram fotografados, no momento da inclusão e alguns ao longo do acompanhamento ambulatorial, para documentação da resposta ao tratamento.

O protocolo da presente pesquisa, assim como o TCLE foram aprovados pelo Conselho do Departamento de Dermatologia da Faculdade de Medicina da Universidade de São Paulo e pela Comissão de Ética em Pesquisa da Diretoria Clínica do HCFMUSP.

\subsection{MÉTODOS}

\subsubsection{INFORMAÇÕES CLÍNICAS}

Foram coletadas, através do protocolo de dados, informações referentes ao perfil dos pacientes, como sexo, idade, e cor. Informações referentes à história clínica como data da primeira consulta, tempo de história pregressa da doença atual, data do diagnóstico e idade do paciente no momento do diagnóstico, foram consideradas.

As lesões cutâneas foram descritas quanto à apresentação clínica. Quanto à localização das lesões, foram descritos o acometimento de um ou 
mais seguimentos corpóreos e a área corpórea total afetada, em porcentagem (menor ou maior que $10 \%$ da SC). Quanto à morfologia, as lesões foram classificadas em patches, pápulas, placas e nódulos. Considerou-se tanto a apresentação dermatológica feita no momento do diagnóstico (análise retrospectiva, por meio de anotações do prontuário clínico) como aquela realizada no momento da seleção.

Em relação ao acometimento sistêmico, foi avaliada a disseminação extracutânea do processo linfoproliferativo. Foi considerado acometimento linfonodal quando a presença de linfonodo anômalo (maior que 1,5 cm ou com consistência alterada) foi detectada ao exame físico (palpação) ou por métodos de imagem (ultrassonografia ou tomografia computadorizada) e confirmada histologicamente através de biópsia. Quanto ao acometimento visceral, foi considerado positivo quando métodos de imagem (ultrassonografia e/ou tomografia computadorizada) e/ou biópsia visceral indicaram presença de infiltração maligna visceral. ${ }^{46}$

Quanto aos exames laboratoriais, foram avaliados hemograma completo, dosagem de desidrogenase lática sérica, sorologia para HTLV-1, pesquisa de células de Sezáry e imunofenotipagem de linfócitos por citometria de fluxo do sangue periférico.

Uma vez completada esta avaliação, o estadiamento do paciente foi feito, seguindo a classificação TNMB. ${ }^{74}$ Tratamentos prévios e vigente foram descritos, assim como as respostas obtidas. 


\subsubsection{HISTOPATOLOGIA}

Lâminas com fragmentos de pele das lesões de MF corados pela Hematoxilina-Eosina (HE) foram avaliados seguindo os critérios histológicos abaixo:

1. Epidermotropismo: presença discreta, moderada ou intensa de células mononucleares na epiderme, e localização das células epidermotrópicas;

2. Características das células epidermotrópicas: tamanho dos linfócitos e presença de atipia, núcleos convolutos, pleomorfismo e halo circundante;

3. Espongiose: ausente, discreta, moderada ou intensa;

4. Acantose, hiperqueratose e paraqueratose focal: presentes ou ausentes;

5. Fibroplasia papilar: presença ou ausência

6. Infiltrado celular dérmico: localização (superficial e/ou profundo) e densidade (discreto, moderado ou intenso);

7. Padrão do infiltrado dérmico superficial (perivascular e/ou liquenoide); 
8. Comprometimento de anexos pelo infiltrado celular: presente ou ausente;

9. Características da composição do infiltrado celular dérmico: presença de linfócitos pequenos e/ou grandes, plasmócitos, eosinófilos e histiócitos.

\subsubsection{IMUNO-HISTOQUÍMICA}

O estudo imuno-histoquímico foi realizado no Laboratório de Dermatopatologia da Divisão de Clínica Dermatológica do HCFMUSP. Foram analisados fragmentos de pele com diagnóstico de MF dos pacientes selecionados; como controle foram utilizados fragmentos de pele obtidos de áreas contralaterais, sem lesões cutâneas, dos pacientes dos grupos A e B. A análise imuno-histoquímica foi realizada na amostra de pele fixada em formalina a $10 \%$ e embebida em parafina, em cortes de $5 \mu \mathrm{m}$ de espessura e colhidos em lâminas histológicas tratadas com solução adesiva de aminopropyltriethoxysilane (Sigma Chemical Co, St. Louis, MO, USA, cód A3648), na concentração de $3 \%$ em acetona PA.

Os cortes histológicos foram desparafinizados em dois banhos em xilol à temperatura ambiente, durante 20 minutos cada. Seguiu-se com a hidratação dos tecidos através de cadeia descendente de etanol, sendo dois 
banhos em etanol absoluto, um banho em etanol $95 \%$, finalizando em um banho de etanol 70\% (cinco minutos cada banho). Em seguida, as lâminas foram lavadas em água corrente por cinco minutos e a seguir lavadas em água destilada, por cinco minutos. Completadas essas etapas, prosseguiuse com as técnicas de recuperação e exposição antigênica do tecido, de acordo com as determinações especificadas pelo fabricante de cada anticorpo marcador e detalhadas na tabela 1. Foram utilizados os seguintes anticorpos:

-Anti-CD3, anti-CD4, anti-CD7 e anti-CD8: para imunofenotipagem do infiltrado linfocítico neoplásico e reacional;

- Melan-A e anti-tirosinase: para identificação dos melanócitos;

-Anti-SCF: para detecção do fator de células-tronco, expresso pelos queratinócitos;

-Anti-CD117 e anti-MITF: para estudo da função melanocítica.

O anticorpo primário foi aplicado sobre os tecidos, procedendo-se à incubação a $4^{\circ} \mathrm{C}$ por uma noite. Os anticorpos foram diluídos em soroalbumina bovina (BSA) 1\%. As diluições de uso, códigos, clones, laboratórios de procedência, recuperação antigênica, controles positivos e cromógenos utilizados constam na tabela 1.

Em seguida, o material foi contracorado levemente, com hematoxilina de Carazzi, seguida de lavagem em água corrente e banho de água destilada, por cinco minutos cada. As lâminas foram secadas à temperatura 
ambiente e montadas com resina Permount (Fisher Scientific, Fair Lawn, NJ, USA, cód SP15-100) sob lamínulas de vidro.

Os cortes histológicos foram digitalizados e avaliados utilizando-se o software Image-Pro Plus Versão 4.5 (Media Cybernetics, Silver Spring, MA, U.S.A.). Para os marcadores CD3, CD4, CD7 e CD8 foi realizada a contagem total dos linfócitos na epiderme e na derme separadamente. A perda da expressão de CD7 foi considerada quando houve imunomarcação de menos de $30 \%$ dos linfócitos epidermotrópicos. ${ }^{75}$

Para a análise da marcação do SCF utilizou-se o método de densidade óptica integrada, considerando-se a intensidade da marcação e área marcada da epiderme. Partindo do pressuposto que os melanócitos localizam-se nas camadas inferiores da epiderme, e que portanto o SCF secretado pelos queratinócitos tem como alvo aquelas células, optamos por avaliar sua marcação nas camadas basal e parabasal: padronizamos a razão dos valores obtidos das camadas inferiores da epiderme pelos valores da extensão total da mesma, para se atingir tal objetivo da aferição.

Quanto aos anticorpos Melan-A, anti-tirosinase, anti-MITF e antiCD117, obteve-se a relação da contagem do número total de melanócitos corados pela extensão da membrana basal (número de melanócitos/ milímetro). Cada mensuração foi realizada sob magnificação constante. Os parâmetros relacionados à melanogênese foram avaliados nas amostras das lesões hipocrômicas e pele sã dos pacientes do grupo A, nas lesões 
hipocrômicas, lesões não-hipocrômicas e pele sã dos pacientes do grupo B e lesões não-hipocrômicas dos pacientes do grupo C. 


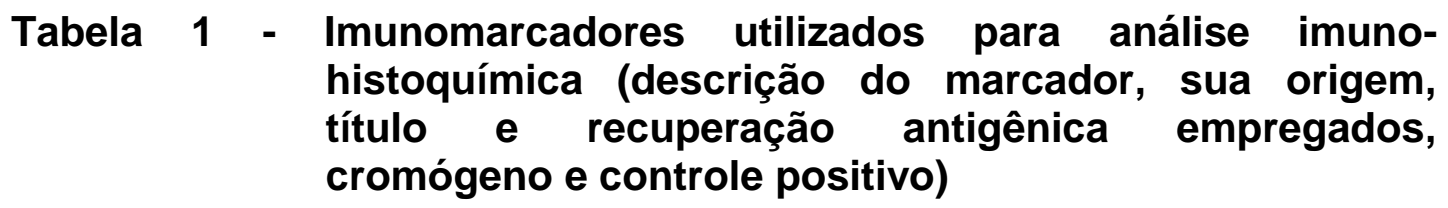

\begin{tabular}{|c|c|c|c|c|c|}
\hline ANTICORPO & ORIGEM & TíTULO & $\begin{array}{l}\text { RECUPERAÇÃO } \\
\text { ANTIGÊNICA }\end{array}$ & CROMÓGENO & $\begin{array}{l}\text { CONTROLE } \\
\text { POSITIVO }\end{array}$ \\
\hline CD3 & $\begin{array}{l}\text { CD3, T-Cell } \\
\text { Clone F7.2.38 } \\
\text { Dako (Denmark) }\end{array}$ & $1: 400$ & $\begin{array}{l}\text { Novolink; banho- } \\
\text { maria } 95^{\circ} \mathrm{C} 25^{\prime}, \\
\text { Retrieval pH } 9.0\end{array}$ & Diamino-benzidina & Tonsila \\
\hline CD4 & $\begin{array}{l}\text { Anti-human CD4 } \\
\text { Clone SP35 } \\
\text { Spring Bioscience } \\
\text { (USA) }\end{array}$ & $1: 100$ & $\begin{array}{l}\text { Advance; panela a } \\
\text { vapor } 25 \text { ', Retrieval } \\
\text { pH } 6.0\end{array}$ & Diamino-benzidina & Tonsila \\
\hline CD7 & $\begin{array}{l}\text { CD7 } \\
\text { Clone LP15 } \\
\text { Novocastra/ Leica } \\
\text { (Germany) }\end{array}$ & $1: 150$ & $\begin{array}{l}\text { Envision Dual; } \\
\text { panela a vapor 3'; } \\
\text { ácido cítrico pH } 6.0\end{array}$ & Diamino-benzidina & Tonsila \\
\hline CD8 & $\begin{array}{l}\text { Anti-human CD8 } \\
\text { Clone c8/144B } \\
\text { Biogen } \\
\text { (Switzerland) }\end{array}$ & $1: 600$ & $\begin{array}{l}\text { Advance; panela a } \\
\text { vapor } 25 \text { ', Retrieval } \\
\text { pH } 9.0\end{array}$ & Diamino-benzidina & Tonsila \\
\hline Melan-A & $\begin{array}{l}\text { Melan-A } \\
\text { Clone A103 } \\
\text { Dako (Denmark) }\end{array}$ & $1: 25$ & $\begin{array}{l}\text { LSAB-AP; banho- } \\
\text { maria } 95^{\circ} \mathrm{C}, 25 " \text {, } \\
\text { Retrieval pH } 6.0\end{array}$ & $\begin{array}{l}\text { Liquid Permanent } \\
\text { Red }\end{array}$ & $\begin{array}{l}\text { Nevo } \\
\text { melanocítico }\end{array}$ \\
\hline Tirosinase & $\begin{array}{l}\text { Tyrosinase } \\
\text { Clone T311 } \\
\text { Dako (Denmark) }\end{array}$ & $1: 50$ & $\begin{array}{l}\text { LSAB-AP; banho- } \\
\text { maria } 95^{\circ} \mathrm{C}, 25 " \\
\text { Retrieval pH } 9.0\end{array}$ & $\begin{array}{l}\text { Liquid Permanent } \\
\text { Red }\end{array}$ & Melanoma \\
\hline SCF & $\begin{array}{l}\text { Moust } \\
\text { monoclonal Clone } \\
\text { IGG2B } \\
\text { Santa Cruz(USA) }\end{array}$ & $1: 100$ & $\begin{array}{l}\text { G2; banho-maria } \\
95^{\circ} \mathrm{C}, 25^{\prime \prime}, \text { Retrieval } \\
\text { pH } 9.0\end{array}$ & $\begin{array}{l}\text { Liquid Permanent } \\
\text { Red }\end{array}$ & Cólon \\
\hline MITF & $\begin{array}{l}\text { Anti-human MITF } \\
\text { Clone D5 } \\
\text { Dako (Denmark) }\end{array}$ & $1: 200$ & $\begin{array}{l}\text { Novolink; banho- } \\
\text { maria } 95^{\circ} \mathrm{C}, 25^{\prime \prime} \\
\text { Retrieval pH } 6.0\end{array}$ & $\begin{array}{l}\text { DAB+ cloreto de } \\
\text { níquel }\end{array}$ & Melanoma \\
\hline CD117 & $\begin{array}{l}\text { CD117, c-kit } \\
\text { Dako (Denmark) }\end{array}$ & $1: 750$ & $\begin{array}{l}\text { LSAB-AP; panela a } \\
\text { vapor no Tris-EDTA } \\
\text { pH9,0 }\end{array}$ & $\begin{array}{l}\text { Liquid Permanent } \\
\text { Red }\end{array}$ & Pele normal \\
\hline
\end{tabular}




\subsection{ANÁLISE ESTATÍSTICA}

Para análise estatística foi utilizado o software STATDISK v.10.4.0: foram descritas a mediana e os intervalos interquartis e utilizados testes nãoparamétricos (teste da soma de postos de Wilcoxon ou teste de KruskalWallis) para rejeitar ou aceitar a hipótese nula $\left(\mathrm{H}_{0}\right)$, para os valores sem distribuição normal. $\mathrm{Na}$ análise das tabelas de contingência (comparação entre o grupo controle e os grupos com doença) foram utilizados o teste do qui-quadrado ou o teste de Fisher, estabelecendo-se nível de significância de $5 \%$. 
RESULTADOS 


\section{RESULTADOS}

\subsection{ASPECTOS CLÍNICOS}

No período de fevereiro de 2009 a outubro de 2011 foram avaliados 229 diferentes pacientes, com diagnóstico de MF/SS; destes, 21 apresentavam quadro clínico composto exclusivamente por lesões hipocrômicas (micose fungoide hipocromiante "pura" -MFh, grupo A) e 15 apresentavam, além de lesões hipocrômicas, lesões com outras características (micose fungoide mista - MFm, grupo B). 8 pacientes portadores de MF sem lesões hipocrômicas foram incluídos no grupo C (para análise comparativa histopatológica e imuno-histoquímica).

A tabela 2 traz os dados dos pacientes do grupo A e a tabela 3 , dos pacientes do grupo B. Dados dos pacientes do grupo C são apresentados no anexo A. 
Tabela 2 - Dados clinicoepidemiológicos dos pacientes do grupo A (idade ${ }^{1}$, idade de início, idade ao diagnóstico, cor, sexo, estadiamento da doença e localização das lesões) Ambulatório de Oncologia Cutânea - Linfomas Cutâneos da Divisão de Clínica do HC-FMUSP - fev 2009 a out 2011

\begin{tabular}{|c|c|c|c|c|c|c|c|}
\hline PACIENTE & $\begin{array}{l}\text { IDADE } \\
\text { (ANOS) }\end{array}$ & $\begin{array}{l}\text { IDADE } \\
\text { INÍCIO } \\
\text { (ANOS) } \\
\end{array}$ & $\begin{array}{c}\text { IDADE AO } \\
\text { DIAGNÓSTICO } \\
\text { (ANOS) }\end{array}$ & COR & SEXO $^{2}$ & ESTADIAMENTO $^{3}$ & $\begin{array}{l}\text { LOCALIZAÇÃO } \\
\text { DAS LESÕES }\end{array}$ \\
\hline A1 & 58 & 50 & 56 & Parda & $M$ & T2NOMOB0 & Tronco/ MMII \\
\hline A2 & 65 & 15 & 46 & Parda & $M$ & T2N1M0B0 & $\begin{array}{l}\text { Tronco/ MMII/ } \\
\text { MMSS }\end{array}$ \\
\hline A3 & 17 & 1 & 8 & Parda & $\mathrm{F}$ & T2NOMOBO & $\begin{array}{l}\text { MMII/ MMSS/ } \\
\text { Tronco }\end{array}$ \\
\hline A4 & 58 & 23 & 38 & Branca & $\mathrm{F}$ & T2NOMOB0 & MMSS/ MMII \\
\hline A5 & 26 & 22 & 22 & Branca & $M$ & T2NOMOBO & $\begin{array}{l}\text { Tronco/ MMSS/ } \\
\text { MMII }\end{array}$ \\
\hline A6 & 47 & 25 & 26 & Parda & $\mathrm{F}$ & T2NOMOBO & MMSS/ MMII \\
\hline A7 & 50 & 45 & 45 & Branca & $\mathrm{F}$ & T1NOMOB0 & Tronco \\
\hline A8 & 31 & 28 & 28 & Parda & M & T2NOMOB0 & $\begin{array}{l}\text { MMII/ Tronco/ } \\
\text { MMSS }\end{array}$ \\
\hline A9 & 24 & 19 & 20 & Parda & $\mathrm{F}$ & T1NOMONO & MMSS/ Tronco \\
\hline A10 & 31 & 22 & 27 & Branca & $F$ & T2NOMOB0 & $\begin{array}{l}\text { MMSS/ MMII/ } \\
\text { Tronco }\end{array}$ \\
\hline A11 & 41 & 24 & 34 & Parda & $\mathrm{F}$ & T1NOMOB0 & MMII/ MMSS \\
\hline A12 & 47 & 30 & 44 & Parda & $F$ & T1N0M0B0 & MMII/ Tronco \\
\hline A13 & 35 & 23 & 25 & Branca & $\mathrm{F}$ & T2NOMOBO & $\begin{array}{l}\text { MMSS/ Tronco/ } \\
\text { MMII }\end{array}$ \\
\hline A14 & 40 & 28 & 32 & Parda & $F$ & T1NOMOB0 & MMSS/ MMII \\
\hline A15 & 24 & 19 & 21 & Amarela & $M$ & T1NOMOB0 & $\begin{array}{l}\text { MMII/ Tronco/ } \\
\text { MMSS }\end{array}$ \\
\hline A16 & 34 & 28 & 33 & Negra & $\mathrm{M}$ & T2NOMOBO & $\begin{array}{l}\text { Tronco/MMII/ } \\
\text { MMSS }\end{array}$ \\
\hline A17 & 32 & 21 & 30 & Branca & $\mathrm{F}$ & T1NOMOB0 & MMII/ MMSS \\
\hline A18 & 48 & 43 & 47 & Parda & $F$ & T1NOMOB0 & $\begin{array}{l}\text { Tronco/ MMSS/ } \\
\text { MMII }\end{array}$ \\
\hline A19 & 35 & 28 & 33 & Parda & $\mathrm{F}$ & T1NOMOB0 & $\begin{array}{l}\text { MMII/ Tronco/ } \\
\text { MMSS }\end{array}$ \\
\hline A20 & 42 & 38 & 42 & Parda & $\mathrm{F}$ & T2NOMOBO & Tronco/ MMII \\
\hline A21 & 51 & 49 & 51 & Parda & $\mathrm{F}$ & T1NOMOB0 & $\begin{array}{l}\text { MMSS/ Tronco/ } \\
\text { MMII }\end{array}$ \\
\hline
\end{tabular}

1. Idade à conclusão do período de observação (outubro de 2011).

2. Sexo M: masculino, sexo F: feminino.

3. Estadiamento sistema TNMB.

4. MMII: membros inferiores, MMSS: membros superiores. 
Tabela 3 - Dados clinicoepidemiológicos dos pacientes do grupo B (idade ${ }^{1}$, idade de início, idade ao diagnóstico, cor, sexo, estadiamento da doença e localização das lesões) Ambulatório de Oncologia Cutânea - Linfomas Cutâneos da Divisão de Clínica do HC-FMUSP - fev 2009 a out 2011

\begin{tabular}{|c|c|c|c|c|c|c|c|}
\hline PACIENTE & IDADE & $\begin{array}{l}\text { IDADE } \\
\text { INÍCIO } \\
\text { (ANOS) } \\
\end{array}$ & $\begin{array}{c}\text { IDADE AO } \\
\text { DIAGNÓSTICO } \\
\text { (ANOS) }\end{array}$ & COR & SEXO $^{2}$ & ESTADIAMENTO $^{3}$ & $\begin{array}{l}\text { LOCALIZAÇÃO } \\
\text { DAS LESÕES }\end{array}$ \\
\hline B1 & 65 & 54 & 55 & Negra & $M$ & T1N0M0B0 & MMII/ Tronco \\
\hline B2 & 28 & 25 & 26 & Parda & $F$ & T2N0M0B0 & $\begin{array}{c}\text { Tronco/MMII/ } \\
\text { MMSS }\end{array}$ \\
\hline B3 & 23 & 10 & 20 & Parda & M & T2NOMOBO & Tronco/ MMII \\
\hline B4 & 38 & 22 & 27 & Negra & M & T1N0M0B0 & Tronco/ MMII \\
\hline B5 & 55 & 22 & 33 & Branca & M & T1N0M0B0 & Tronco/ MMII \\
\hline B6 & 47 & 41 & 43 & Parda & $\mathrm{M}$ & T1N0M0B0 & $\begin{array}{c}\text { MMII/ Tronco/ } \\
\text { MMSS }\end{array}$ \\
\hline B7 & 71 & 30 & 43 & Branca & $\mathrm{F}$ & T2N1M0B0 & $\begin{array}{c}\text { Tronco/MMII/ } \\
\text { MMSS }\end{array}$ \\
\hline B8 & 33 & 28 & 30 & Parda & $F$ & T2NOMOBO & $\begin{array}{c}\text { Tronco/MMII/ } \\
\text { MMSS }\end{array}$ \\
\hline B9 & 33 & 17 & 33 & Parda & $M$ & T2N0MOBO & Tronco/ MMII \\
\hline B10 & 47 & 38 & 43 & Parda & $F$ & T2NOMOB0 & $\begin{array}{c}\text { MMII/ Tronco/ } \\
\text { MMSS }\end{array}$ \\
\hline B11 & 49 & 40 & 44 & Parda & $\mathrm{F}$ & T1N0M0B0 & MMII/ Tronco \\
\hline B12 & 55 & 44 & 47 & Parda & $\mathrm{F}$ & T1N0M0B0 & MMII \\
\hline B13 & 36 & 22 & 28 & Parda & $\mathrm{F}$ & T2NOMOBO & MMII \\
\hline B14 & 56 & 35 & 54 & Parda & $\mathrm{F}$ & T2NOMOBO & MMII/ Tronco \\
\hline B15 & 51 & 29 & 39 & Negra & $\mathrm{F}$ & T1N0M0B0 & $\begin{array}{c}\text { MMSS/ MMII/ } \\
\text { Tronco }\end{array}$ \\
\hline
\end{tabular}

A tabela 4 mostra a análise dos dados apresentados anteriormente nas tabelas 2 e 3 (os mesmos dados são apresentados através de gráficos boxplot no anexo B). Avaliando-se os dois grupos, observamos que a mediana das idades dos pacientes de ambos é menor que a usualmente descrita nos pacientes com MF clássica, sendo que o grupo com pacientes da forma pura de MF hipocromiante (grupo A) este valor é ainda inferior ao obtido nos pacientes com forma mista (grupo B) $(p<0,05)$. Tal observação se repete quando avaliadas as medianas das idades de início da doença e 
idades ao diagnóstico: a as medianas são menores que as esperadas para pacientes com MF, e o grupo A teve as menores medianas (ambos com $p<0,05)$. O diagnóstico é tardio, sendo que a mediana dos tempos entre início da doença e diagnóstico foi de 4 anos para o grupo A e 5 anos para o grupo B $(p<0,05)$. Outro ponto a se destacar é o tempo de doença, prolongado e sem evolução para estádios mais avançados da doença (como veremos em seguida). Encontramos um paciente com 50 anos de história no grupo A e 41 anos de evolução no grupo B. A mediana dos tempos de doença do grupo $B$ foi maior que a do grupo $A(p<0,05)$.

Estes pacientes ficaram em sua maioria restritos aos estágios iniciais IA (T1NOMOBO) e IB (T2NOMOB0) da doença (T1NOMOBO: acometimento estritamente cutâneo, com SC atingida < 10\% e T2NOMOB0: acometimento estritamente cutâneo, com SC afetada $>10 \%$ ), sem diferenças entre os grupos ( $p=1$, para cada estágio). Apenas dois pacientes (um de cada grupo) apresentaram linfonodomegalia durante a evolução e que, quando biopsiado - linfonodo aumentando, este revelou apenas linfadenite dermopática (ambos com estádio IIA - T2N1M0B0). Coincidentemente, são os dois pacientes com maior tempo de história de doença (50 e 41 anos, respectivamente). 
Tabela 4 - Análise comparativa dos dados clinicoepidemiológicos dos pacientes dos grupos A e B (idade ${ }^{1}$, idade de início, idade ao diagnóstico, tempo de doença, cor, sexo, localização das lesões e estadiamento) - Ambulatório de Oncologia Cutânea - Linfomas Cutâneos da Divisão de Clínica do HC-FMUSP fev 2009 a out 2011

\begin{tabular}{|c|c|c|c|c|}
\hline & & GRUPO A & GRUPO B & $p$ \\
\hline \multirow[t]{3}{*}{ Idade ${ }^{1,2}$} & Mediana & 40 & 47 & $<0,05^{5}$ \\
\hline & Mínima & 17 & 23 & \\
\hline & Máxima & 65 & 71 & \\
\hline \multirow[t]{3}{*}{ Idade (início) ${ }^{2}$} & Mediana & 25 & 29 & $<0,05^{5}$ \\
\hline & Mínima & 1 & 10 & \\
\hline & Máxima & 50 & 54 & \\
\hline \multirow[t]{3}{*}{ Idade (diagnóstico) ${ }^{2}$} & Mediana & 33 & 39 & $<0,05^{5}$ \\
\hline & Mínima & 8 & 20 & \\
\hline & Máxima & 56 & 55 & \\
\hline \multirow[t]{3}{*}{ Tempo de doença ${ }^{2}$} & Mediana & 8 & 13 & $<0,05^{5}$ \\
\hline & Mínima & 3 & 3 & \\
\hline & Máxima & 50 & 41 & \\
\hline \multirow[t]{4}{*}{ Cor } & Branca & 6 & 2 & $0,42^{6}$ \\
\hline & Parda & 13 & 10 & \\
\hline & Negra & 1 & 3 & \\
\hline & Amarela & 1 & 0 & \\
\hline \multirow[t]{2}{*}{ Sexo } & Masculino & 6 & 6 & $0,72^{7}$ \\
\hline & Feminino & 15 & 9 & \\
\hline \multirow[t]{3}{*}{$\begin{array}{l}\text { Localização das } \\
\text { lesões }{ }^{3}\end{array}$} & Tronco & 16 & 13 & $0,67^{7}$ \\
\hline & MMSS & 17 & 6 & $0,02^{7}$ \\
\hline & MMII & 19 & 15 & $0,5^{7}$ \\
\hline \multirow[t]{3}{*}{ Estadiamento ${ }^{4}$} & T1NOMOBO - IA & 10 & 7 & $1^{7}$ \\
\hline & T2NOMOBO - IB & 10 & 7 & $1^{7}$ \\
\hline & T2N1M0B0 - IIA & 1 & 1 & $1^{7}$ \\
\hline
\end{tabular}

1. Idade à conclusão do período de observação (outubro de 2011).

2. Idades e tempo de doença em anos.

3. MMII: membros inferiores, MMSS: membros superiores.

3. Estadiamento sistema TNMB.

5. Teste da soma de postos de Wilcoxon.

6. Teste de Fisher para melanodérmicos vs. caucasianos.

7. Teste de Fisher. 
Realizamos também a avaliação de idade e sexo dos demais pacientes diagnosticados com outras formas de MF/ SS sem lesões hipocrômicas, acompanhados no ambulatório. No total, obtivemos 193 pacientes, que apresentaram mediana das idades de 59 anos (mínima 13, máxima 88); 98 eram do sexo masculino e 95, feminino. Quando comparamos estes resultados com os obtidos nos grupos A e B e apresentados anteriormente, constatamos que a idade dos pacientes com lesões hipocrômicas é inferior a da população geral de pacientes com outras formas de MF/ SS e que os pacientes com variante hipocromiante pura (grupo A) apresentavam a menor mediana das idades $(p<0,001)$. Em relação ao gênero, constatou-se diferença significativa em relação a ambos os grupos $(p<0,001)$, mostrandose assim predomínio da manifestação hipocromiante no sexo feminino. $O$ gráfico 1 compara a frequência das formas de MF acima relatadas. 
Figura 1

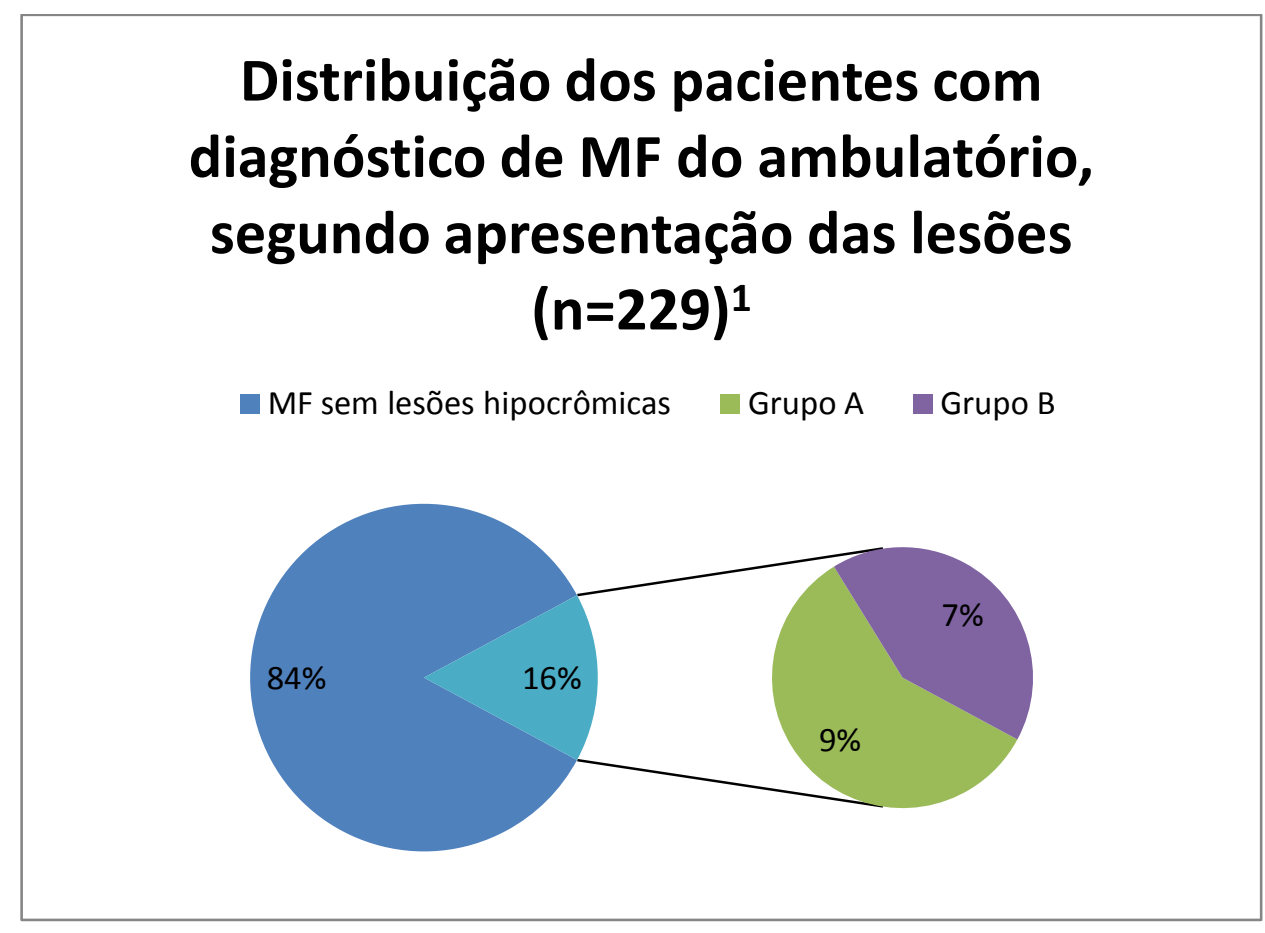

1. Ambulatório de Linfomas Cutâneos da Divisão de Dermatologia do HC-FMUSP - fev 2009 a out 2011.

Quando considerado o quadro clínico, os pacientes do grupo A só apresentaram lesões sob a forma de "patch" (ou seja, lesões não-infiltradas), mesmo aqueles com longo tempo de evolução. A forma mais comumente descrita foi a de máculas hipocrômicas, de bordas mal-delimitadas, tamanho variável (menores de $1 \mathrm{~cm}$ a mais de $10 \mathrm{~cm}$ de diâmetro), algumas com descamação fina. Contudo, variações também foram descritas, como lesões gotadas, lenticulares, de limites bem-definidos, assim como lesões acrômicas e vitiligoides. As figuras 2, 3 e 4 trazem imagens das lesões identificadas nos pacientes do grupo A. Dos pacientes do grupo B, sete já 
apresentavam lesões na forma de placas (com infiltração), porém todas estas eram lesões não-hipocrômicas. O padrão das lesões hipocrômicas nos pacientes do grupo B foi o semelhante ao encontrado naqueles pacientes do grupo A. Alguns pacientes apresentavam lesões mistas, com áreas de hipocromia e áreas da lesão concomitante (como eritematosa, poiquilodérmica, hipercrômica). A figura 5 mostra algumas das diferentes formas de lesões dos pacientes do grupo B.

\section{Figura 2}

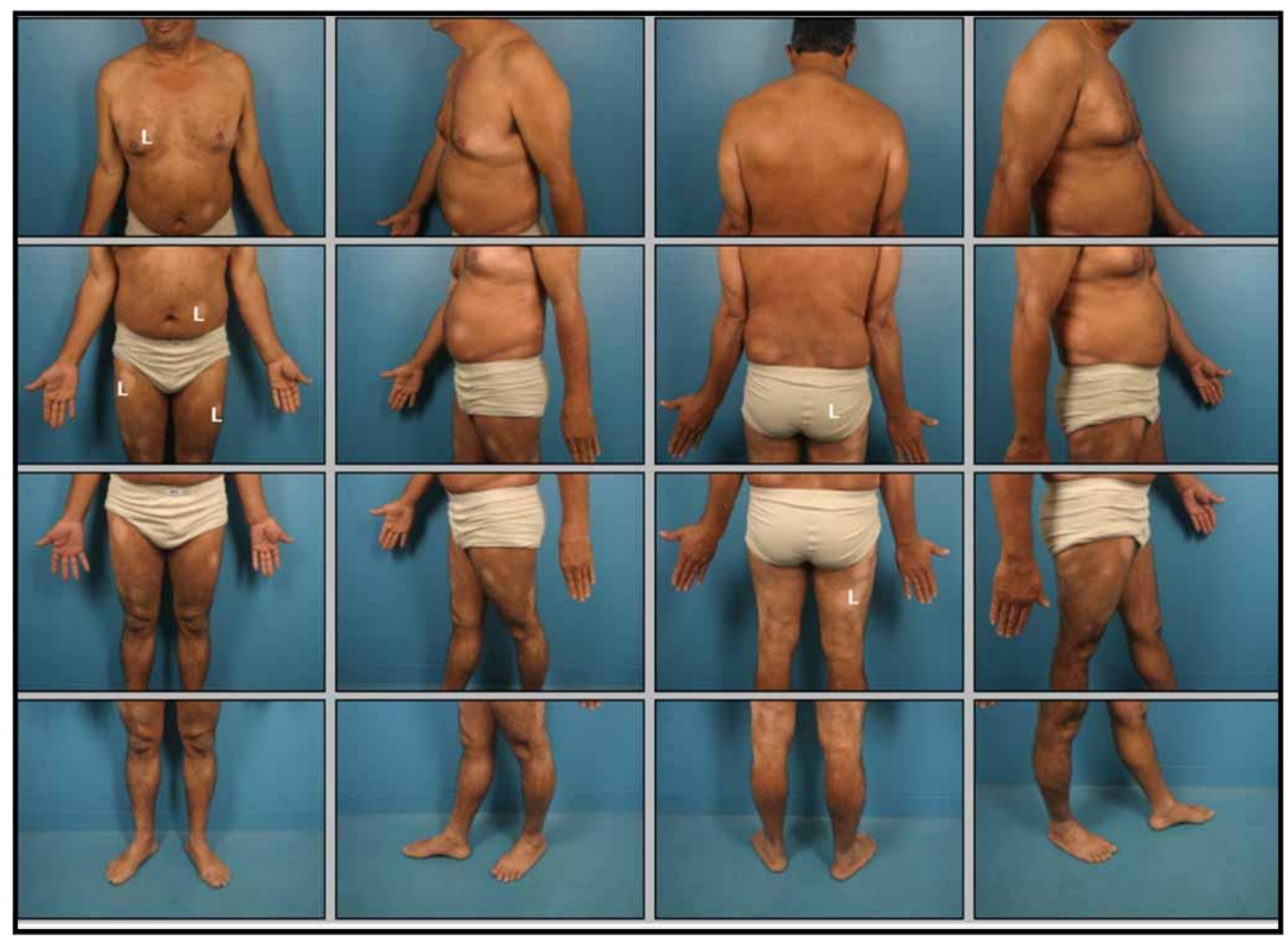

Fig. 2 - Apresentação clínica dos pacientes do grupo A. Mapeamento corporal do paciente "A1" do grupo A, que apresenta "patches" hipocrômicos (marcados com "L") distribuídos no tronco, MMSS e MMII (SC>10\%) 
Figura 3
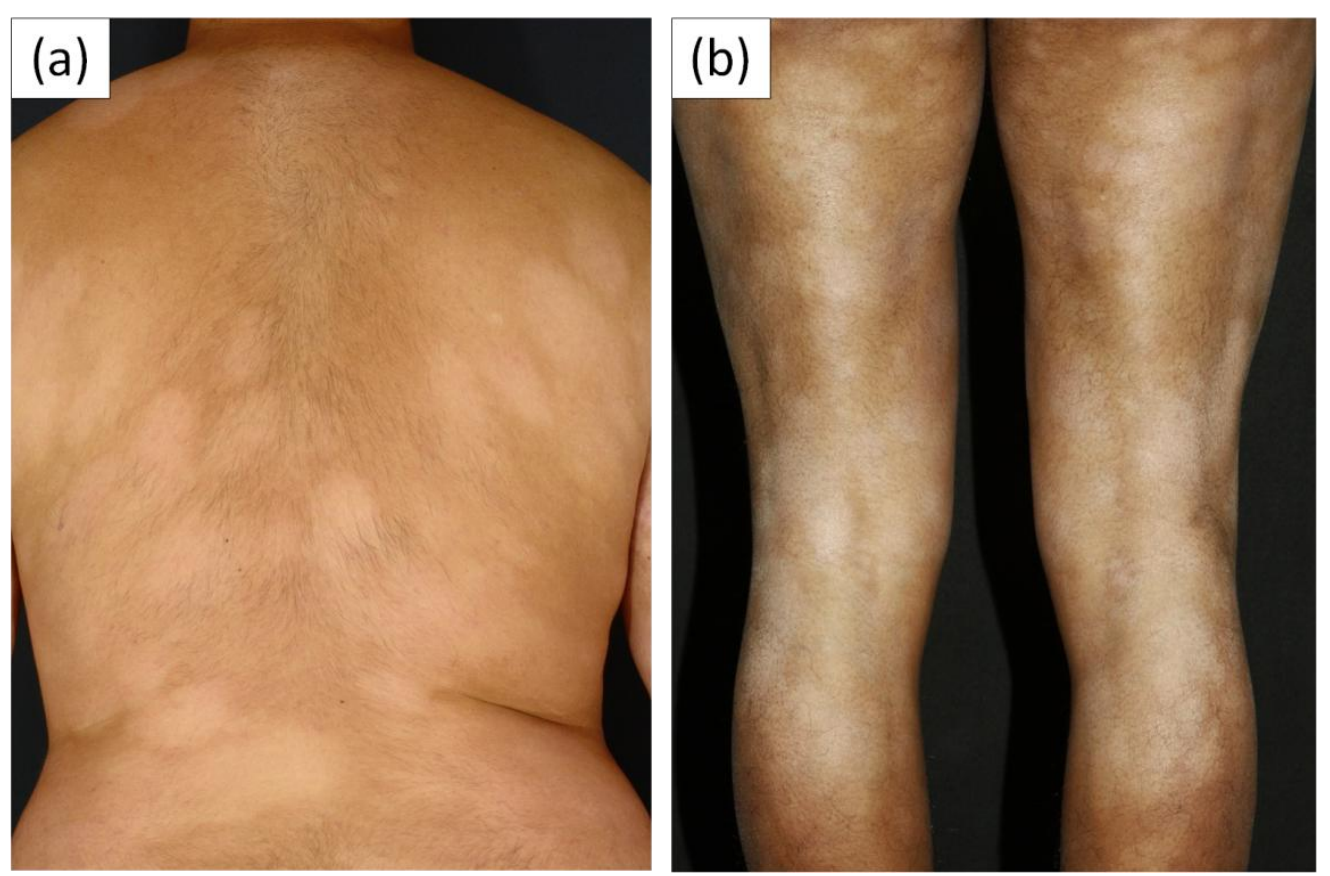

Fig. 3 - Apresentação clínica dos pacientes do grupo A. Típicos "patches" hipocrômicos no dorso do paciente "A5" (a) e na face posterior dos MMII do paciente "A8" (b), ambos do grupo A 


\section{Figura 4}

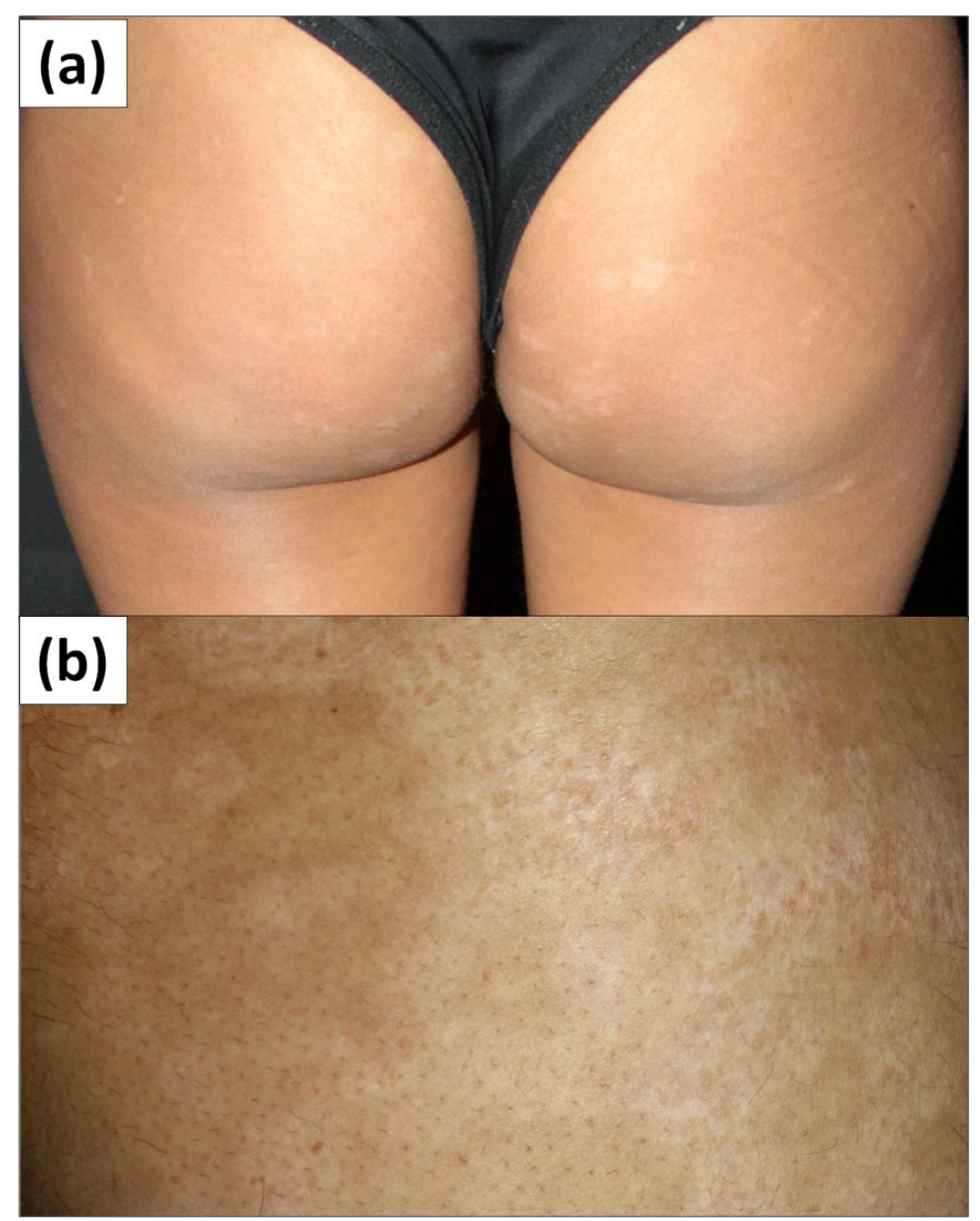

Fig. 4 - Apresentação clínica dos pacientes do grupo A. Variações morfológicas das lesões de MF apresentadas por alguns pacientes do grupo A: paciente "A17" com lesões lenticulares hipocrômicas/ acrômicas na região glútea (a); paciente "A15" com lesões vitiligoides no membro inferior direito 


\section{Figura 5}

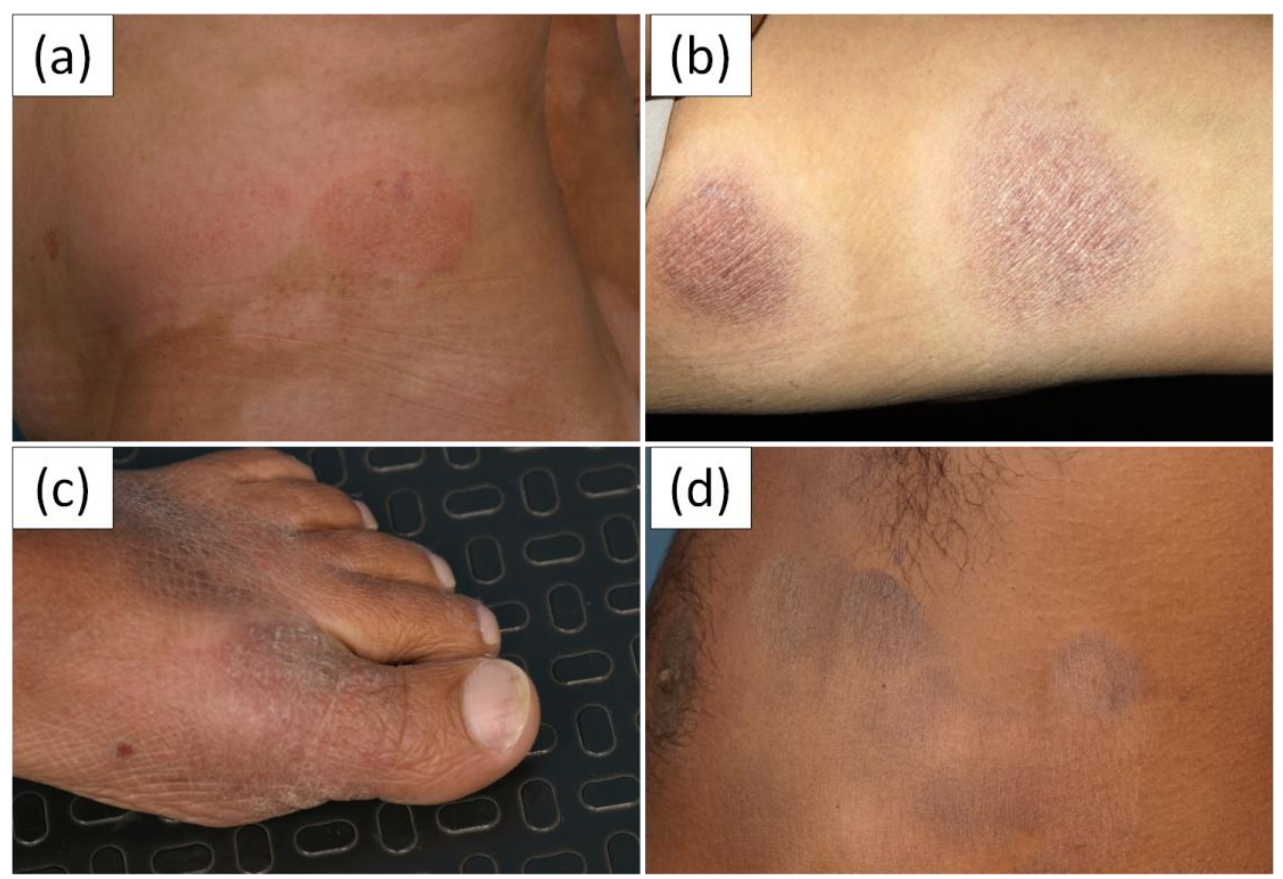

Fig. 5 - Apresentação clínica dos pacientes do grupo B. Algumas das lesões não-hipocrômicas apresentadas pelos pacientes: (a) placas eritematosas (paciente "B14"); (b) "patches" poiquilodérmicos na coxa direita (paciente "B11"); (c) placas queratósicas no dorso do pé esquerdo (paciente "B6"); (d) "patches" hipercrômicos na axila esquerda (paciente "B4")

O acometimento exclusivamente por "patches" dos pacientes com MF hipocromiante pura foi significativo $(p=0,001)$. A tabela 5 refere-se à morfologia das lesões não-hipocrômicas encontradas nos pacientes do grupo B (alguns pacientes apresentavam mais de uma forma de lesão). 
Tabela 5 - Descrição da morfologia das lesões não-hipocrômicas identificadas nos pacientes do grupo $B$ e número de pacientes portadores das mesmas - Ambulatório de Oncologia Cutânea - Linfomas Cutâneos da Divisão de Clínica do HC-FMUSP - fev 2009 a out 2011

\begin{tabular}{cc}
\hline TIPO DE LESÃO & NÚMERO DE PACIENTES \\
\hline Poiquilodérmica & 6 \\
Eritematosa & 4 \\
Hipercrômica & 3 \\
Purpúrica & 2 \\
Queratósica & 1 \\
Foliculotrópica & 1 \\
\hline
\end{tabular}

Como vimos anteriormente, estes pacientes tem uma longa história de doença, sendo assim submetidos a várias modalidades de tratamento. Como a maioria dos pacientes se apresentou e permaneceu em estágios iniciais da doença, a terapêutica dominante foi dirigida à pele. Predominaram a corticoterapia tópica (corticoides fluorados e não-fluorados) e fototerapia (PUVA e UVB-nb). A orientação seguida no ambulatório é iniciar o tratamento com fototerapia UVB-nb; na ausência de resposta, muda-se para a fotoquimioterapia PUVA. Os corticoides são empregados quando restam poucas lesões residuais após a fototerapia, ou por motivos sociais (impedimento do paciente para comparecer às sessões de fototerapia). Apenas um paciente (do grupo B) encontra-se em terapêutica sistêmica, recebendo interferon-alfa. A tabela 6 relaciona a melhor resposta apresentada por paciente a alguma modalidade de tratamento. 
Tabela 6 - Descrição da modalidade de tratamento empregada para cada paciente, dos grupos A e B, além do tipo de resposta (remissão total, parcial, doença estável ou progressão da doença) - Ambulatório de Oncologia Cutânea - Linfomas Cutâneos da Divisão de Clínica do HC-FMUSP - fev 2009 a out 2011

\begin{tabular}{|c|c|}
\hline PACIENTE & TRATAMENTO - MELHOR RESPOSTA \\
\hline \multicolumn{2}{|l|}{ Grupo A } \\
\hline A1 & UVB- nb: remissão parcial \\
\hline A2 & UVB- nb: remissão parcial \\
\hline A3 & UVB- nb: remissão parcial \\
\hline A4 & UVB-nb e PUVA: remissões totais \\
\hline A5 & UVB- nb: remissão parcial \\
\hline A6 & UVB- nb: remissão total \\
\hline A7 & PUVA: remissão total \\
\hline A8 & UVB- nb: remissão parcial \\
\hline A9 & UVB- nb: doença estável \\
\hline A10 & UVB- nb: remissão parcial \\
\hline A11 & PUVA: remissão total \\
\hline A12 & UVB- nb: remissão total \\
\hline A13 & PUVA: remissão total \\
\hline A14 & PUVA: remissão total \\
\hline A15 & UVB- nb: remissão parcial \\
\hline A16 & UVB- nb: remissão parcial \\
\hline A17 & UVB- nb: remissão total \\
\hline A18 & Hidrocortisona tópica: doença estável \\
\hline A19 & UVB- nb: remissão parcial \\
\hline A20 & UVB-nb: remissão parcial \\
\hline A21 & UVB-nb: doença estável \\
\hline
\end{tabular}

Grupo B

B1 PUVA + IFN- $\alpha$ : remissão parcial

B2 PUVA: remissão parcial

B3

UVB- nb: remissão parcial 
Tabela 6 - Descrição da modalidade de tratamento empregada para cada paciente, dos grupos A e B, além do tipo de resposta (remissão total, parcial, doença estável ou progressão da doença) - Ambulatório de Oncologia Cutânea - Linfomas Cutâneos da Divisão de Clínica do HC-FMUSP - fev 2009 a out 2011 (conclusão)

\begin{tabular}{cc}
\hline PACIENTE & TRATAMENTO - MELHOR RESPOSTA \\
\hline Grupo B & UVB- nb: remissão parcial \\
\hline B5 & Betametasona tópica: remissão parcial \\
\hline B6 & Hidrocortisona tópica no tronco e clobetasol tópico em mãos/pés: \\
\hline B7 & remissão parcial \\
\hline B8 & UUVA, mostarda nitrogenada: remissões parciais \\
B9 & UVB-nb e PUVA: doença estável \\
B10 & UVB- nb: remissão parcial \\
B11 & PUVA: progressão da doença \\
B12 & UVB- nb: remissão parcial \\
B13 & Terapia fotodinâmica (3 sessões): doença estável \\
B14 & UVB- nb: remissão parcial \\
B15 & UVB- nb: remissão parcial \\
\hline
\end{tabular}

Como podemos observar na tabela 6 , houve cinco remissões totais com PUVA e quatro remissões totais com UVB-nb, todas no grupo A. Não foi constatada nenhuma remissão completa no grupo B.

De modo complementar, encerrado o período de observação deste estudo (outubro de 2011), dois pacientes apresentaram evolução do quadro clínico: 
- Paciente "A1", do grupo $A$, compareceu às consultas de rotina apresentando "patches" eritematosos (deixando de apresentar um quadro puramente constituído de lesões hipocrômicas);

- Paciente "B2", do grupo B, evoluiu com formação de lesões tumorais e aumento dos linfonodos axilares e inguinais $(1,5$ a 2,0 cm de diâmetro). Biópsia de um linfonodo axilar revelou linfadenite dermopática; pesquisa de rearranjo gênico do TCR mostrou população monoclonal para o gene gama. População monoclonal para o gene gama também foi identificada em nova biópsia de pele e sangue periférico. Seu estágio passou a ser T3N1M0B0.

\subsection{ASPECTOS HISTOPATOLÓGICOS}

A avaliação histológica encontra-se detalhada na tabela 7. 
Tabela 7 - Descrição dos achados histopatológicos, identificados nas biópsias das lesões dos pacientes do grupo A (lesão hipocrômica), grupo B (lesões hipocrômica e nãohipocrômica) e grupo C (lesão não-hipocrômica)

\begin{tabular}{|c|c|c|c|c|}
\hline & \multirow{2}{*}{$\begin{array}{c}\text { GRUPO A } \\
\begin{array}{c}\text { Lesão } \\
\text { hipocrômica } \\
(n=20)\end{array}\end{array}$} & \multicolumn{2}{|c|}{ GRUPO B } & \multirow{2}{*}{$\begin{array}{c}\text { GRUPO C } \\
\begin{array}{c}\text { Lesão não- } \\
\text { hipocrômica }(n=8)\end{array}\end{array}$} \\
\hline & & $\begin{array}{c}\text { Lesão } \\
\text { hipocrômica } \\
(n=14)^{1}\end{array}$ & $\begin{array}{l}\text { Lesão não- } \\
\text { hipocrômica } \\
(\mathrm{n}=15)^{1,2}\end{array}$ & \\
\hline \multicolumn{5}{|l|}{ Epiderme } \\
\hline Acantose & $11(55 \%)$ & $13(93 \%)$ & $9(60 \%)$ & $6(75 \%)$ \\
\hline Hiperqueratose & $11(55 \%)$ & $5(36 \%)$ & $8(53 \%)$ & $4(50 \%)$ \\
\hline Paraqueratose & $8(40 \%)$ & $5(36 \%)$ & $4(27 \%)$ & $3(38 \%)$ \\
\hline Espongiose & $8(40 \%)$ & $8(57 \%)$ & $13(87 \%)$ & $4(50 \%)$ \\
\hline \multicolumn{5}{|l|}{ Epidermotropismo } \\
\hline${ }^{*}$ Leve & $8(40 \%)$ & $9(64 \%)$ & $7(47 \%)$ & $4(50 \%)$ \\
\hline * Moderado & 11 (55\%) & $3(21 \%)$ & 5 (33\%) & $1(13 \%)$ \\
\hline * Intenso & $1(5 \%)$ & $2(14 \%)$ & $3(20 \%)$ & $3(38 \%)$ \\
\hline Linfócitos com halo & 20 (100\%) & $12(86 \%)$ & $14(93 \%)$ & $4(50 \%)$ \\
\hline $\begin{array}{l}\text { Microabscessos de } \\
\text { Pautrier }\end{array}$ & $12(60 \%)$ & $5(36 \%)$ & $8(53 \%)$ & $3(38 \%)$ \\
\hline $\begin{array}{l}\text { Linfócitos em várias } \\
\text { camadas }\end{array}$ & $16(80 \%)$ & $11(79 \%)$ & $11(73 \%)$ & $4(50 \%)$ \\
\hline $\begin{array}{l}\text { Línfócitos na } \\
\text { camada basal }\end{array}$ & 17 (85\%) & $12(86 \%)$ & $15(100 \%)$ & $6(75 \%)$ \\
\hline \multicolumn{5}{|l|}{$\begin{array}{l}\text { Tamanho dos } \\
\text { linfócitos }\end{array}$} \\
\hline * Pequenos & $10(50 \%)$ & $7(50 \%)$ & $5(33 \%)$ & $5(63 \%)$ \\
\hline * Médios & $14(70 \%)$ & $9(64 \%)$ & $14(93 \%)$ & $4(50 \%)$ \\
\hline${ }^{*}$ Grandes & $3(15 \%)$ & 0 & $1(7 \%)$ & 0 \\
\hline Atipia linfocitária & $13(65 \%)$ & $8(57 \%)$ & $11(73 \%)$ & $4(50 \%)$ \\
\hline $\begin{array}{l}\text { Pleomorfismo } \\
\text { linfocitário }\end{array}$ & $5(25 \%)$ & 7 (50\%) & $10(67 \%)$ & $3(38 \%)$ \\
\hline $\begin{array}{l}\text { Núcleos linfocitários } \\
\text { convolutos }\end{array}$ & $5(25 \%)$ & $8(57 \%)$ & $9(60 \%)$ & $3(38 \%)$ \\
\hline \multicolumn{5}{|l|}{ Derme } \\
\hline Fibroplasia papilar & $14(70 \%)$ & $4(29 \%)$ & $6(40 \%)$ & $3(38 \%)$ \\
\hline $\begin{array}{l}\text { Infiltrado } \\
\text { inflamatório } \\
\text { superficial }\end{array}$ & 19 (95\%) & $13(93 \%)$ & $15(100 \%)$ & $8(100 \%)$ \\
\hline * Leve & $12(63 \%)$ & $12(86 \%)$ & $6(40 \%)$ & $4(50 \%)$ \\
\hline * Moderado & $632 \%)$ & $2(14 \%)$ & 7 (47\%) & $4(50 \%)$ \\
\hline * Intenso & $1(5 \%)$ & 0 & $2(13 \%)$ & 0 \\
\hline * Liquenoide & 7 (37\%) & $4(29 \%)$ & $12(80 \%)$ & $3(38 \%)$ \\
\hline${ }^{*}$ Perivascular & $19(100 \%)$ & $13(93 \%)$ & $10(67 \%)$ & $8(100 \%)$ \\
\hline $\begin{array}{l}\text { Infiltrado } \\
\text { inflamatório } \\
\text { profundo }\end{array}$ & $1(5 \%)$ & $1(7 \%)$ & $3(20 \%)$ & 0 \\
\hline $\begin{array}{l}\text { Comprometimento } \\
\text { anexial }\end{array}$ & $1(5 \%)$ & 0 & $1(7 \%)$ & 0 \\
\hline
\end{tabular}


Tabela 7 - Descrição dos achados histopatológicos, identificados nas biópsias das lesões dos pacientes do grupo A (lesão hipocômica), grupo B (lesões hipocrômica e nãohipocrômica) e grupo C (lesão não-hipocrômica) (conclusão)

\begin{tabular}{|c|c|c|c|c|}
\hline & \multirow{2}{*}{$\begin{array}{c}\text { GRUPO A } \\
\begin{array}{c}\text { Lesão } \\
\text { hipocrômica } \\
(n=20)\end{array}\end{array}$} & \multicolumn{2}{|c|}{ GRUPO B } & \multirow{2}{*}{$\begin{array}{c}\text { GRUPO C } \\
\text { Lesão não- } \\
\text { hipocrômica }(n=8)\end{array}$} \\
\hline & & $\begin{array}{c}\text { Lesão } \\
\text { hipocrômica } \\
(n=14)^{1}\end{array}$ & $\begin{array}{l}\text { Lesão não- } \\
\text { hipocrômica }(n=15)^{1,2}\end{array}$ & \\
\hline \multicolumn{5}{|l|}{ Derme } \\
\hline \multicolumn{5}{|l|}{$\begin{array}{l}\text { Tamanho dos } \\
\text { linfócitos }\end{array}$} \\
\hline * Pequenos & 19 (100\%) & $14(100 \%)$ & 15 (100\%) & $8(100 \%)$ \\
\hline * Grandes & $2(11 \%)$ & $4(29 \%)$ & 7 (47\%) & 3 (38\%) \\
\hline Histiócitos & 19 (100\%) & $14(100 \%)$ & 15 (100\%) & $8(100 \%)$ \\
\hline Plasmócitos & 0 & 0 & $1(7 \%)$ & $5(63 \%)$ \\
\hline Eosinófilos & 0 & 0 & $1(7 \%)$ & 0 \\
\hline
\end{tabular}

1. Lâminas das pacientes "A12" e "B13" não estavam disponíveis para avaliação

2. Duas biópsias, provenientes de lesões de morfologia diferente do paciente "B4" foram avaliadas.

A figura 6 detalha os achados histológicos de uma caso de MFh do grupo A. 
Figura 6

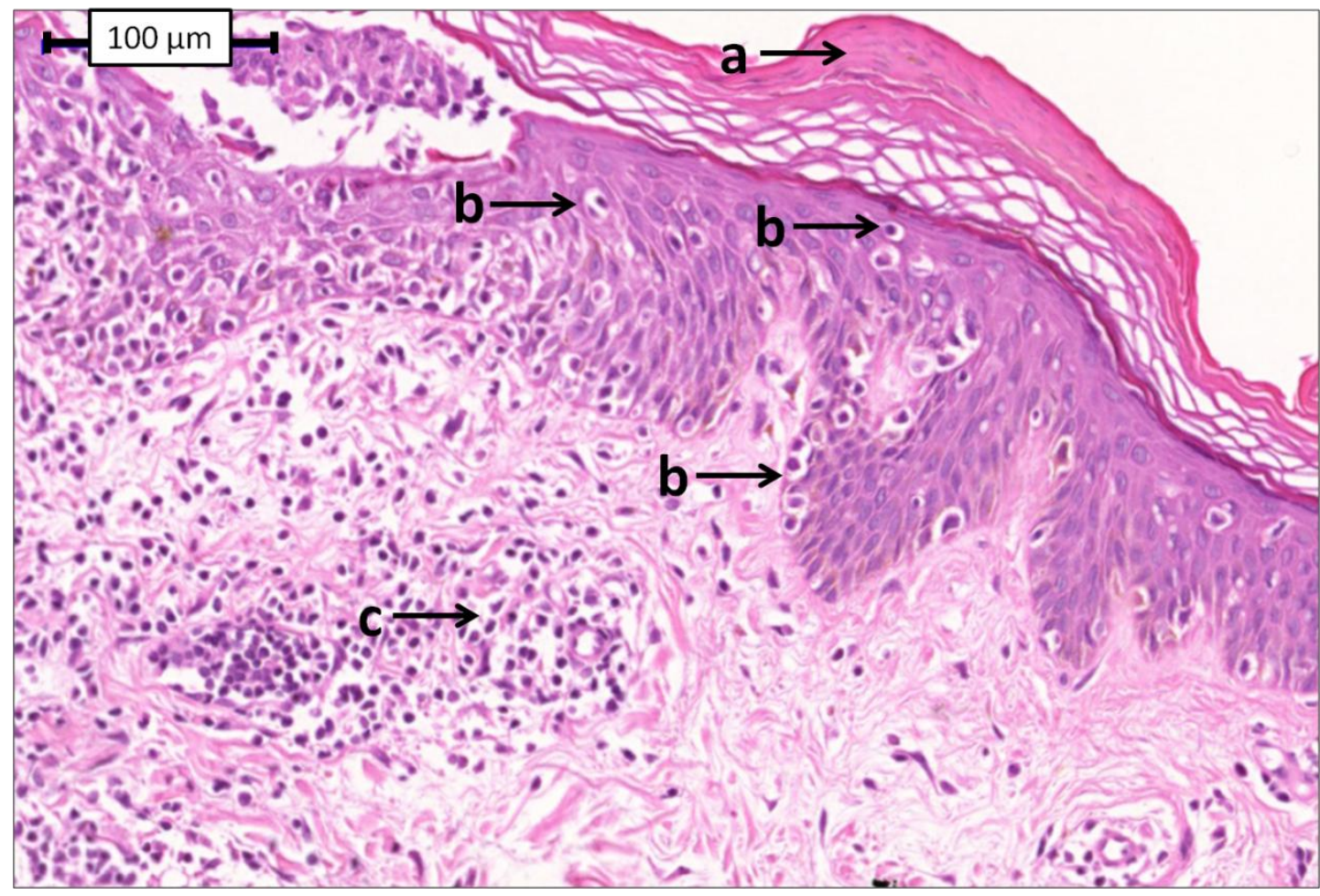

Fig. 6 - Microfotografia apresenta alguns dos achados diagnósticos de uma lesão hipocrômica de MF, do paciente A15 do grupo A: (a) paraqueratose; (b) linfócitos em várias camadas da epiderme, inclusive camada basal; (c) infiltrado linfomonocitário perivascular dérmico

\subsection{ASPECTOS IMUNO-HISTOQUÍMICOS}

A avaliação imuno-histoquímica do infiltrado neoplásico foi realizado em 20 casos do grupo A, 14 do grupo B e 8 casos do grupo $C$ (novamente, não houve material adequado para se realizar esta avaliação das pacientes "A12" e "B13"). A tabela 8 apresenta o imunofenótipo da neoplasia e a perda da expressão de CD7 (menos de 30\% dos linfócitos epidérmicos marcados) dos casos de cada grupo. Os mesmos dados são analisados na tabela 9 e figura 7. 
Tabela 8 - Perfil imunofenotípico do infiltrado epidermotrópico e perda da expressão de CD7 dos linfócitos epidérmicos, das lesões hipocrômicas dos pacientes do grupo A, das lesões hipocrômicas e não-hipocrômicas do grupo $B$ e das lesões não-hipocrômicas do grupo $\mathrm{C}$

\begin{tabular}{|c|c|c|c|c|}
\hline Paciente & \multicolumn{2}{|c|}{ Lesão hipocrômica } & \multicolumn{2}{|c|}{ Lesão não-hipocrômica } \\
\hline & Imunofenótipo & Perda de CD7 & Imunofenótipo & Perda de CD7 \\
\hline A1 & CD8 & $\mathrm{N}$ & & \\
\hline A2 & CD4 & $\mathrm{S}$ & & \\
\hline A3 & CD8 & $\mathrm{N}$ & & \\
\hline A4 & CD8 & S & & \\
\hline A5 & CD8 & S & & \\
\hline A6 & CD8 & $\mathrm{S}$ & & \\
\hline A7 & CD8 & $\mathrm{s}$ & & \\
\hline A8 & CD8 & S & & \\
\hline A9 & CD8 & S & & \\
\hline A10 & CD4 & S & & \\
\hline A11 & CD8 & S & & \\
\hline A13 & CD8 & S & & \\
\hline A14 & CD8 & S & & \\
\hline A15 & CD8 & S & & \\
\hline A16 & CD8 & S & & \\
\hline A17 & CD8 & S & & \\
\hline A18 & CD8 & S & & \\
\hline A19 & CD8 & S & & \\
\hline A20 & CD4 & S & & \\
\hline A21 & CD4 & S & & \\
\hline B1 & CD4 & S & CD4 & S \\
\hline B2 & CD4 & $\mathrm{S}$ & CD4 & S \\
\hline B3 & CD4 & $\mathrm{S}$ & CD4 & $\mathrm{S}$ \\
\hline B4 & CD4 & S & CD4 & S \\
\hline B5 & CD8 & S & CD8 & $\mathrm{S}$ \\
\hline B6 & CD4 & S & CD4 & S \\
\hline B7 & CD8 & $\mathrm{S}$ & CD4 & S \\
\hline B8 & $\mathrm{CD} 4=\mathrm{CD} 8$ & S & $\mathrm{CD} 4=\mathrm{CD} 8$ & S \\
\hline B9 & CD4 & S & CD4 & S \\
\hline B10 & CD4 & S & CD4 & S \\
\hline B11 & CD4 & S & CD4 & S \\
\hline B12 & $\mathrm{CD} 4=\mathrm{CD} 8$ & $\mathrm{~S}$ & CD4 & S \\
\hline B14 & CD4 & S & CD4 & S \\
\hline B15 & CD8 & $\mathrm{S}$ & CD4 & S \\
\hline & & & & \\
\hline C1 & & & CD4 & S \\
\hline C2 & & & CD4 & S \\
\hline C3 & & & CD4 & S \\
\hline C4 & & & CD4 & $\mathrm{N}$ \\
\hline C5 & & & $\mathrm{CD} 4=\mathrm{CD} 8$ & S \\
\hline C6 & & & CD4 & S \\
\hline C7 & & & CD4 & $\mathrm{N}$ \\
\hline C8 & & & CD4 & $\mathrm{N}$ \\
\hline
\end{tabular}

S: $\operatorname{sim}$ (perda de expressão de CD7 em mais de $70 \%$ dos linfócitos) $\mathrm{N}$ : não (expressão de CD7 em mais de $30 \%$ dos linfócitos) 
Tabela 9 - Perfil imunofenotípico do infiltrado epidermotrópico, das lesões hipocrômicas dos pacientes do grupo A, das lesões hipocrômicas e não-hipocrômicas do grupo B e das lesões não-hipocrômicas do grupo C

\begin{tabular}{l|c|cc|c}
\hline & GRUPO A (N=20) & \multicolumn{2}{|c|}{ GRUPO B (N=14) } & GRUPO C (N=8) \\
\hline & $\begin{array}{c}\text { Lesão } \\
\text { hipocrômica }\end{array}$ & $\begin{array}{c}\text { Lesão } \\
\text { hipocrômica }\end{array}$ & $\begin{array}{c}\text { Lesão não- } \\
\text { hipocrômica }\end{array}$ & $\begin{array}{c}\text { Lesão não- } \\
\text { hipocrômica }\end{array}$ \\
CD4 & $4(20 \%)$ & $9(64 \%)$ & $12(86 \%)$ & $7(88 \%)$ \\
CD8 & $16(80 \%)$ & $3(22 \%)$ & $1(7 \%)$ & 0 \\
CD4=CD8 & 0 & $2(14 \%)$ & $1(7 \%)$ & $1(12 \%)$ \\
\hline
\end{tabular}

O predomínio de infiltrado neoplásico epidérmico CD8+ do grupo A foi significante em relação ao grupo B (p=0,001, considerando-se 0 imunofenótipo das lesões hipocrômicas) e em relação ao grupo $C(p=0,002)$. Em todos os casos de lesões hipocrômicas dos grupos A e B, mesmo naqueles com imunofenótipo CD4+ do infiltrado epidermotrópico, foram visualizados linfócitos CD8+ na epiderme. As figuras 8 e 9 ilustram a análise histológica e imunofenotípica de um caso do grupo A e do grupo B, respectivamente. 


\section{Figura 7}

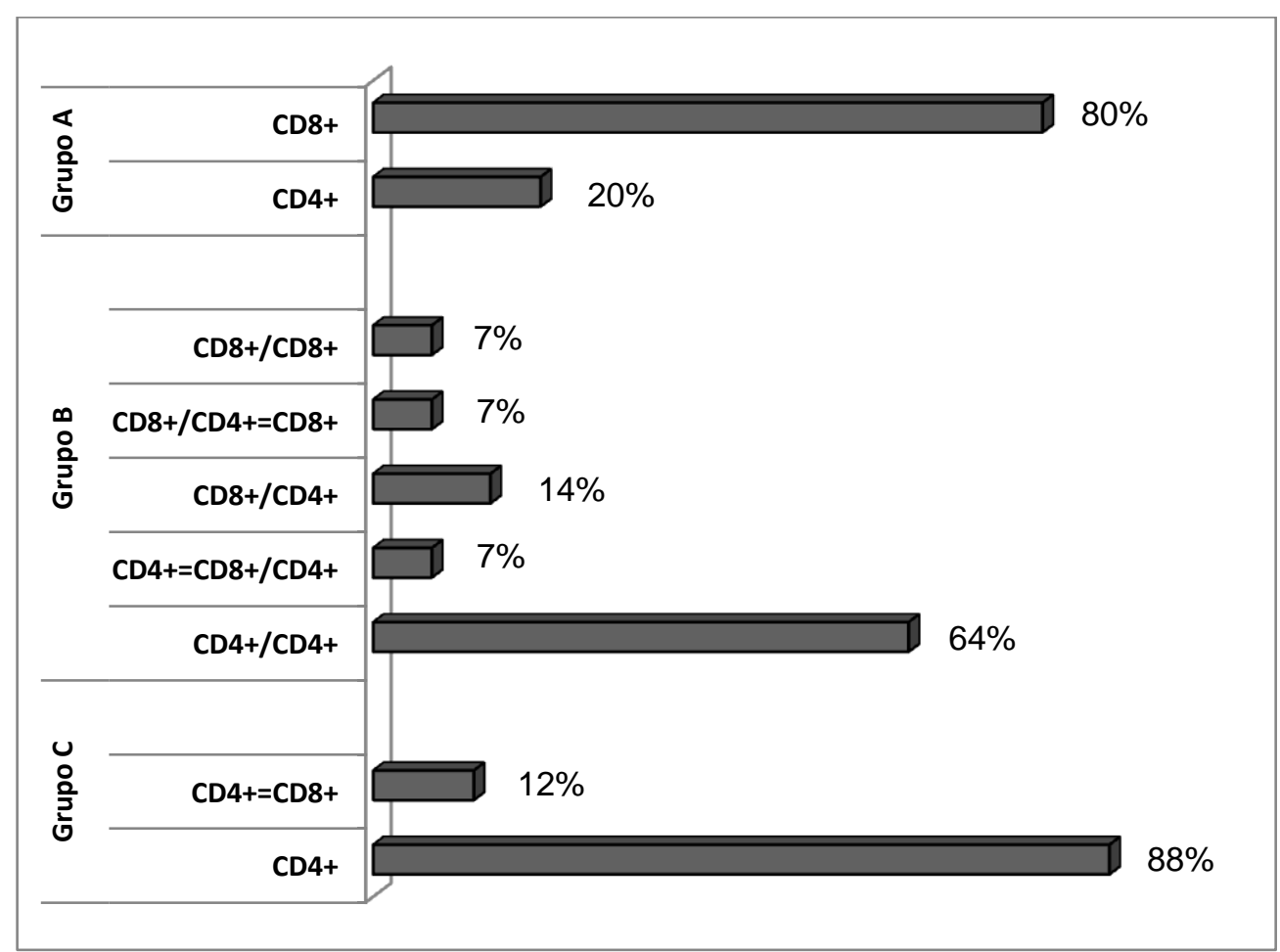

Fig. 7 - Análise imunofenotípica do infiltrado epidermotrópico (porcentagem dos imunofenótipos, dentro de cada grupo). Este gráfico resume os achados da avaliação imuno-histoquímica do imunofenótipo dos pacientes dos grupos A, B e C, em porcentagem do total de casos por grupo. No grupo A, é demonstrado o predomínio do imunofenótipo CD8+ (16/20 casos). Em relação ao grupo B, são descritos os imunofenótipos das lesões hipocrômicas/ não-hipocrômicas por paciente; houve um maior número de casos com lesões hipocrômica/ não-hipocrômica CD4+/CD4+ (9/14). No grupo $\mathrm{C}$, o típico perfil imunofenotípico $\mathrm{CD} 4+$ da MF clássica predomina $(7 / 8)$ 


\section{Figura 8}
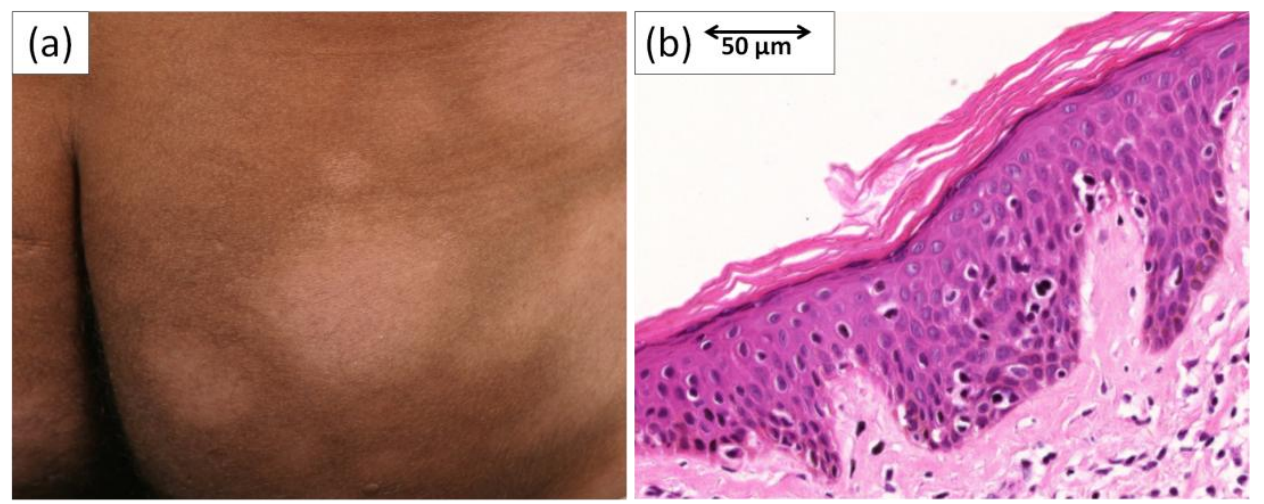

(c) $\stackrel{50 \mu \mathrm{m}}{\longrightarrow}$

(d) $\stackrel{\longleftrightarrow}{50 \mathrm{~m}}$

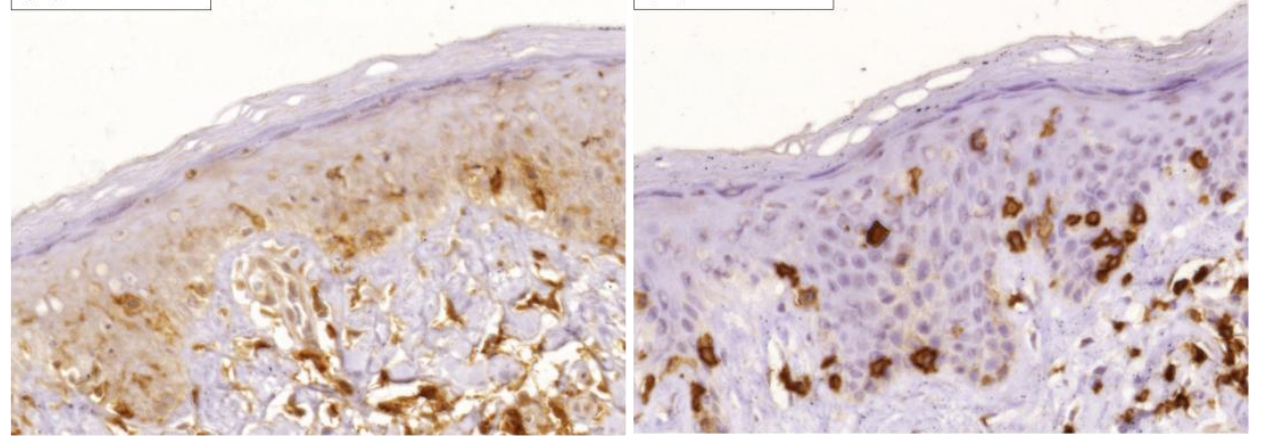

Fig. 8 - Exemplo de análise histológica e imuno-histoquímica de um caso do grupo A. Paciente "A1". Biópsia realizada a partir de lesão hipocrômica na região glútea (a). Análise histológica (b) revelou epidermotropismo de linfócitos atípicos com halo; análise imunohistoquímica (c: CD4 e d:CD8) mostrou predomínio de linfócitos CD8+ 


\section{Figura 9}
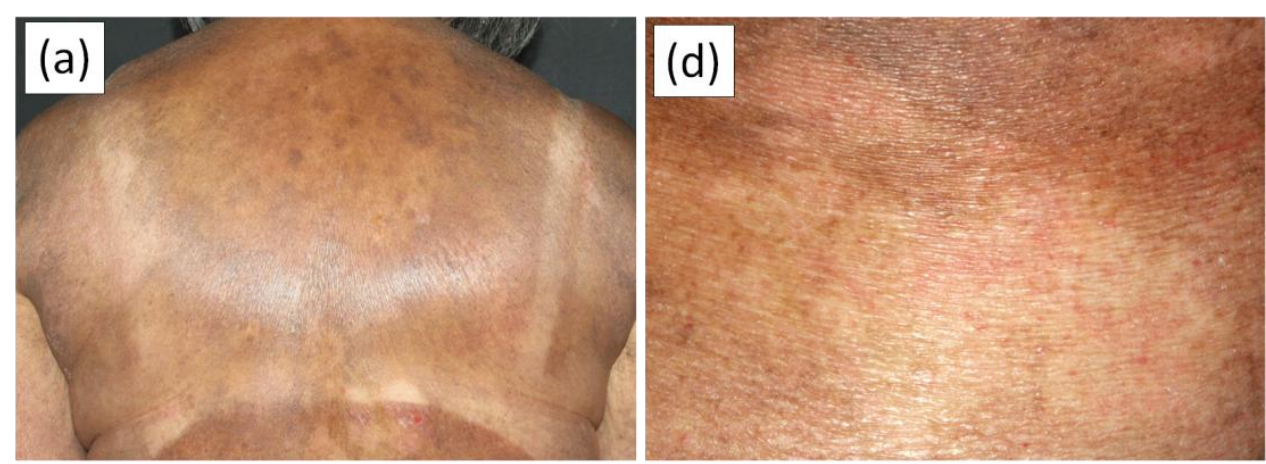

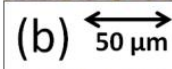

(e) $\stackrel{\longleftrightarrow}{50 \mu m}$

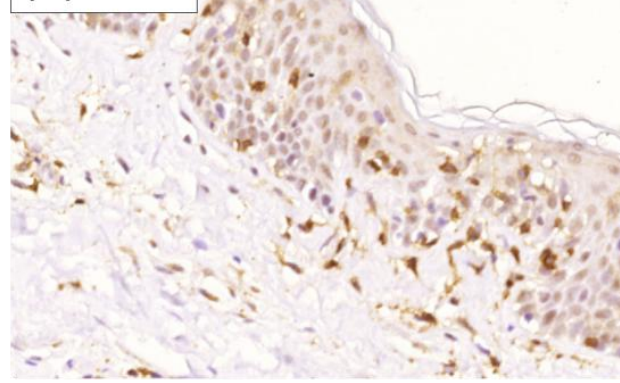

(c) $\stackrel{\longleftrightarrow}{50 \mathrm{~m}}$
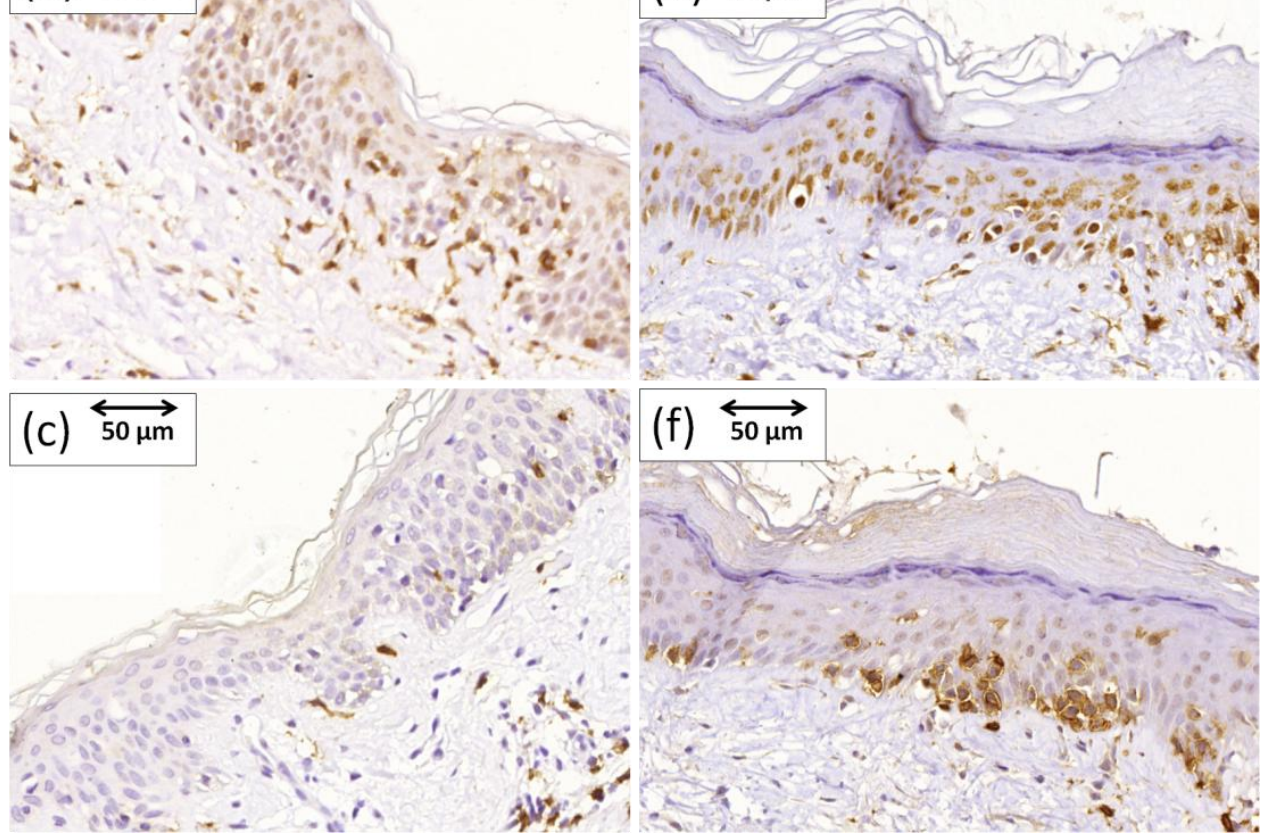

(f) $\overleftrightarrow{50 \mu \mathrm{m}}$

Fig 9 - Exemplo de análise histológica e imuno-histoquímica de um caso do grupo B. Paciente "B7". Biópsia realizada a partir de lesão poiquilodérmica no dorso (a) mostrou predominância de linfócitos epidermotrópicos CD4+ (b) sobre linfócitos CD8+ (c). Já a biópsia de lesão hipocrômica (d), também no dorso, apresentou maior número de linfócitos epidermotrópicos CD8+ (f) que células T CD4+ (e)

A perda da expressão de CD7 foi demonstrada em $90 \%$ dos casos do grupo A, $100 \%$ dos casos do grupo B (perda visualizada em ambas as lesões -hipocrômica/ não-hipocrômica, de cada paciente) e $63 \%$ dos casos 
do grupo C. Em relação ao grupo C (controle), houve diferença significante apenas em relação ao Grupo B $(p=0,04)$.

Para a avaliação dos padrões de imunomarcação dos melanócitos foram analisados:

- Grupo A: 18 casos de lesões hipocrômicas e 18 amostras de pele normal (provenientes dos mesmos pacientes)

-Grupo B: 14 casos de lesões hipocrômicas, 14 casos de lesões não-hipocrômicas e 10 amostras de pele normal (também provenientes dos mesmos pacientes)

-Grupo C: 8 casos de lesões não-hipocrômicas

As amostras de lesões e pele normal dos demais pacientes (grupos A e B) não analisados não estiveram disponíveis para avaliação.

A figura 10 apresenta os padrões de marcação do melanócito (MelanA, tirosinase, CD117 e MITF de uma lesão hipocrômica de um paciente do grupo A, de um controle pele normal do mesmo paciente do grupo $A$ e de uma lesão não-hipocrômica de um paciente do grupo C. 
Figura 10

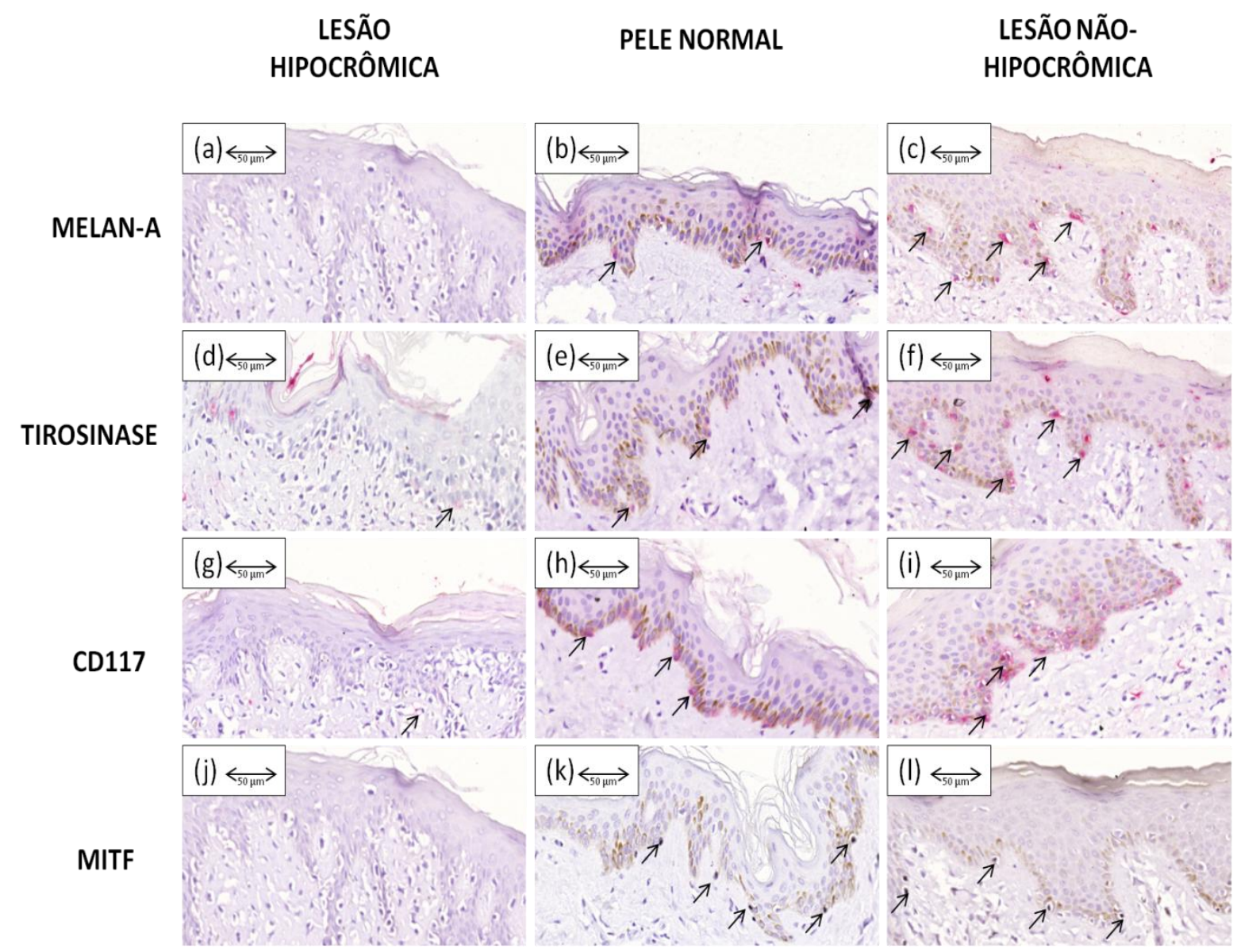

Fig 10 - Padrões de marcação melanocítica. Há redução dos melanócitos marcados (apontados na figura por setas) por todos imunomarcadores na lesão hipocrômica (a, d, g, j), em comparação com os melanócitos marcados na amostra de pele normal (b, e, h, k) e na lesão nãohipocrômica (c, f, i, l)

Para avaliação dos resultados obtidos (inclusive análise estatística) optou-se por comparar os resultados das lesões hipocrômicas dos pacientes do grupo $A$, amostras de pele sã dos mesmos pacientes do grupo $A$ e lesões não-hipocrômicas dos pacientes do grupo C. Já para o grupo B foi realizada a análise internamente, comparando-se os resultados das lesões hipocrômicas, lesões não-hipocrômicas e pele sã dos mesmos pacientes. 
As tabelas 10 e 11 trazem os resultados observados para os marcadores de melanócitos (Melan-A, tirosinase, CD117 e MITF): a tabela 10 apresenta os dados referentes ao grupo A (lesão hipocrômica e pele normal) e grupo C (lesão não-hipocrômica); já a tabela 11 refere-se aos resultados dos pacientes do grupo B (lesão hipocrômica, pele normal e lesão não-hipocrômica).

Tabela 10 - Imunomarcação dos melanócitos pelos marcadores MelanA, tirosinase, CD117 e MITF, das amostras de pele dos pacientes dos grupos A (lesão hipocrômica e pele normal) e C (lesão não-hipocrômica); (resultados demonstrados em melanócitos/ $\mathrm{mm}$ de membrana basal, mediana e intervalo interquartis Q3-Q1)

\begin{tabular}{ccccc}
\hline MARCADOR & $\begin{array}{c}\text { LESÃO } \\
\text { HIPOCRÔMICA } \\
\text { (GRUPO A) }\end{array}$ & $\begin{array}{c}\text { PELE NORMAL } \\
\text { (GRUPO A) }\end{array}$ & $\begin{array}{c}\text { LESÃO NÃO- } \\
\text { HIPOCRÔMICA } \\
\text { (GRUPO C) }\end{array}$ & $\boldsymbol{p}$ \\
\hline MELAN-A & $\begin{array}{c}1,97 \\
(4,1-1,01)\end{array}$ & $\begin{array}{c}4,77 \\
(6,01-3,10)\end{array}$ & $\begin{array}{c}5,42 \\
(7,68-4,03)\end{array}$ & 0,005 \\
\hline TIROSINASE & $\begin{array}{c}2,19 \\
(3,76-0,79)\end{array}$ & $\begin{array}{c}4,02 \\
(5,02-2,94)\end{array}$ & $\begin{array}{c}5,26 \\
(7,33-3,64)\end{array}$ & 0,011 \\
\hline CD117 & $\begin{array}{c}4,29 \\
(6,28-2,12)\end{array}$ & $\begin{array}{c}7,81 \\
(9,84-5,80)\end{array}$ & $\begin{array}{c}5,45 \\
(6,34-3,44)\end{array}$ & 0,006 \\
\hline MITF & $\begin{array}{c}2,75 \\
(3,34-1,92)\end{array}$ & $\begin{array}{c}4,43 \\
(5,84-3,47)\end{array}$ & $\begin{array}{c}5,42 \\
(6,86-3,36)\end{array}$ & 0,005 \\
\hline
\end{tabular}


Tabela 11 - Imunomarcação dos melanócitos pelos marcadores MelanA, tirosinase, CD117 e MITF, das amostras de pele dos pacientes dos grupo B (lesão hipocrômica, pele normal e lesão não-hipocrômica); (resultados demonstrados em melanócitos/ $\mathrm{mm}$ de membrana basal, mediana e intervalo interquartis Q3-Q1)

\begin{tabular}{ccccc}
\hline MARCADOR & LESÃO HIPOCRÔMICA & PELE NORMAL & $\begin{array}{c}\text { LESÃO NÃO- } \\
\text { HIPOCRÔMICA }\end{array}$ & $\boldsymbol{p}$ \\
\hline MELAN-A & $\begin{array}{c}1,83 \\
(3,58-1,1)\end{array}$ & $\begin{array}{c}4,28 \\
(5,53-3,22)\end{array}$ & $\begin{array}{c}4,74 \\
(6,45-2,55)\end{array}$ & 0,007 \\
\hline TIROSINASE & $\begin{array}{c}3,52 \\
(5,17-1,9)\end{array}$ & $\begin{array}{c}3,21 \\
(5,09-2,51)\end{array}$ & $\begin{array}{c}4,99 \\
(7,39-2,25)\end{array}$ & 0,218 \\
\hline CD117 & $\begin{array}{c}4,38 \\
(5,58-2,3)\end{array}$ & $\begin{array}{c}5,29 \\
(6,62-4,34)\end{array}$ & $\begin{array}{c}6,43 \\
(7,84-4,04)\end{array}$ & 0,191 \\
\hline MITF & $\begin{array}{c}3,86 \\
(4,91-2,52)\end{array}$ & $\begin{array}{c}4,44 \\
(6,21-3,62)\end{array}$ & $\begin{array}{c}5,20 \\
(6,24-3,61)\end{array}$ & 0,151 \\
\hline
\end{tabular}

Comparando-se os resultados das imunomarcações melanocíticas das lesões hipocrômicas do grupo A com os resultados das lesões hipocrômicas do grupo B não se observou diferença significante $(p>0,05)$ para todos os marcadores (Melan, tirosinase, CD117 e MITF). Também se realizou comparação semelhante entre os resultados das lesões não-hipocrômicas do grupo $B$ com as lesões não-hipocrômicas do grupo $C$ e novamente não foi encontrada diferença significante $(p>0,05)$ para todos os marcadores.

Observamos alterações no padrão de expressão do SCF pelos queratinócitos nas lesões hipocrômicas, principalmente às dos pacientes do grupo A: a distribuição foi irregular, como marcação heterogênea dos queratinócitos, com áreas intensamente marcadas entremeadas com áreas 
com pouca marcação; além disso foi evidente a ausência de expressão do SCF nas camadas inferiores da epiderme (basal e parabasal). Já nas amostras de pele normal a expressão do SCF foi homogênea entre todas as camadas epidérmicas, sem áreas de interrupção. As lesões nãohipocrômicas também apresentaram, embora de maneira mais sutil, alterações na expressão do SCF, com irregularidade na expressão. Contudo, observou-se marcação nas camadas inferiores, ainda que mínima. Essas alterações descritas podem ser visualizadas na figura 11. Devido a essa diferença no padrão de marcação do SCF, e considerando-se a localização dos melanócitos, optou-se por avaliar este parâmetro através da razão dos valores obtidos da avaliação das camadas inferiores (basal e parabasal) da epiderme em relação aos valores obtidos da avaliação de toda a epiderme.

\section{Figura 11}

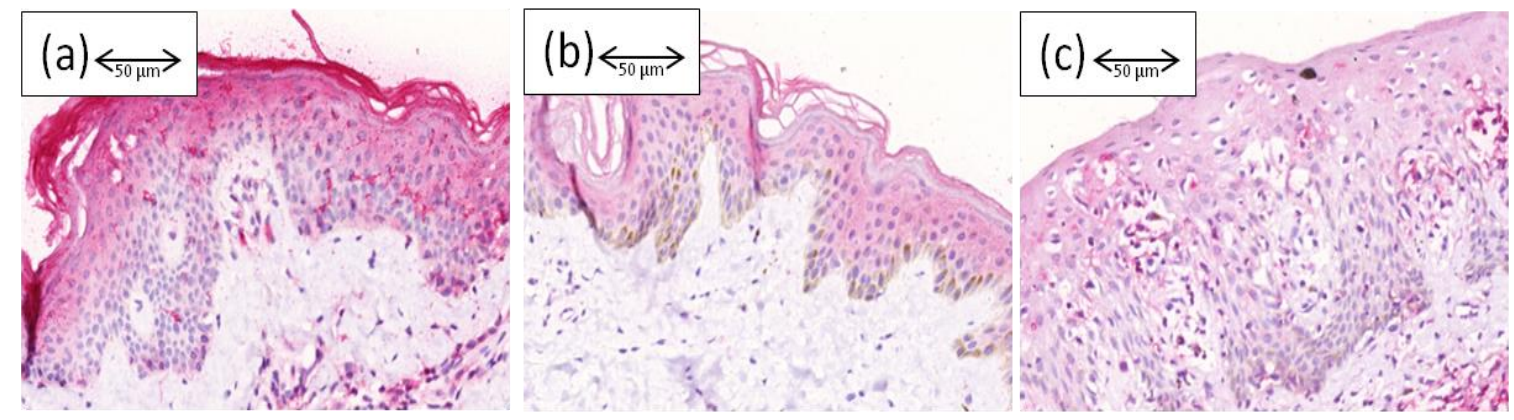

Fig 11 - Padrões de imunomarcação do SCF na epiderme: (a) Lesão hipocrômica de paciente do grupo A apresentou marcação epidérmica do SCF irregular (aumentada nas camadas superiores e reduzida nas inferiores); (b) Amostra de pele normal, também de paciente do grupo A, mostrando expressão regular do SCF; (c) Lesão não-hipocrômica de paciente do grupo C, cuja irregularidade da marcação do SCF foi mais sutil que a observada nas lesões hipocrômicas 
A tabela 12 resume os dados obtidos da observação da marcação pelo anti-SCF nos casos dos grupos A (lesão hipocrômica e pele normal) e C (lesão não-hipocrômica). A tabela 13 traz os mesmos dados, obtidos dos pacientes do grupo B (lesão hipocrômica, pele sã e lesão não-hipocrômica).

Tabela 12 - Resultados da análise da imunomarcação epidérmica do SCF, grupos A (lesão hipocrômica e pele normal) e C (lesão não-hipocrômica); valores obtidos a partir das razões da porcentagem da epiderme inferior marcada/ porcentagem da epiderme total marcada (para avaliação da área) e intensidade da marcação da epiderme inferior/ intensidade da marcação da epiderme total (para avaliação da intensidade da marcação); mediana e intervalo interquartis Q3-Q1

\begin{tabular}{|c|c|c|c|c|}
\hline & $\begin{array}{c}\text { LESÃO } \\
\text { HIPOCRÔMICA } \\
\text { (GRUPO A) }\end{array}$ & $\begin{array}{c}\text { PELE } \\
\text { NORMAL } \\
\text { (GRUPO A) }\end{array}$ & $\begin{array}{l}\text { LESÃO NÃO- } \\
\text { HIPOCRÔMICA } \\
\text { (GRUPO C) }\end{array}$ & $p$ \\
\hline $\begin{array}{l}\text { Percentual da epiderme } \\
\text { inferior marcada/ } \\
\text { percentual da epiderme } \\
\text { total marcada }\end{array}$ & $\begin{array}{c}0,41 \\
(0,53-0,32)\end{array}$ & $\begin{array}{c}0,45 \\
(0,56-0,39)\end{array}$ & $\begin{array}{c}0,53 \\
(0,59-0,48)\end{array}$ & $<0,001$ \\
\hline $\begin{array}{l}\text { Intensidade da marcação } \\
\text { da epiderme inferior/ } \\
\text { intensidade da marcação } \\
\text { da epiderme total }\end{array}$ & $\begin{array}{c}0,78 \\
(0,88-0,70)\end{array}$ & $(0,98-0,91)$ & $\begin{array}{c}0,86 \\
(0,88-0,83)\end{array}$ & $<0,001$ \\
\hline
\end{tabular}


Tabela 13 - Resultados da análise da imunomarcação epidérmica do SCF, grupo B (lesão hipocrômica, pele normal e lesão nãohipocrômica); valores obtidos a partir das razões da porcentagem da epiderme inferior marcada/ porcentagem da epiderme total marcada (para avaliação da área) e intensidade da marcação da epiderme inferior/ intensidade da marcação da epiderme total (para avaliação da intensidade da marcação); mediana e intervalo interquartis Q3-Q1

\begin{tabular}{ccccc}
\hline & $\begin{array}{c}\text { LESÃO } \\
\text { HIPOCRÔMICA }\end{array}$ & $\begin{array}{c}\text { PELE } \\
\text { NORMAL }\end{array}$ & $\begin{array}{c}\text { LESÃO NÃO- } \\
\text { HIPOCRÔMICA }\end{array}$ & $p$ \\
\hline $\begin{array}{c}\text { Porcentagem da epiderme } \\
\text { inferior marcada/ } \\
\text { porcentagem da epiderme } \\
\text { total marcada }\end{array}$ & 0,33 & 0,36 & 0,46 & $<0,001$ \\
\hline $\begin{array}{c}\text { Intensidade da marcação da } \\
\text { epiderme inferior/ intensidade } \\
\text { da marcação da epiderme }\end{array}$ & 0,87 & $(0,49-0,29)$ & $(0,5-0,34)$ & \\
total & $(0,91-0,82)$ & $(0,96-0,84)$ & $(0,86-0,79)$ & $<0,001$ \\
\hline
\end{tabular}

Comparou-se também os resultados das imunomarcações do SCF das lesões hipocrômicas do grupo A com os resultados das lesões hipocrômicas do grupo B e não houve diferença significante $(p>0,05)$, assim como a comparação entre os resultados das lesões não-hipocrômicas do grupo B com as lesões não-hipocrômicas do grupo $C(p>0,05)$.

Os resultados das imunomarcações dos melanócitos (pelo Melan-A, tirosinase, CD117 e MITF) e do SCF epidérmico são também apresentados na forma de boxplot nos anexos C, D, E e F. 
Não foi possível a avaliação dos mecanismos fisiopatogênicos segundo o imunofenótipo da neoplasia (CD4+ ou CD8+), nem intragrupos (casos CD4+ versus casos CD8+ do grupo A e casos CD4+ versus casos CD8+ do grupo B) nem inter-grupos (casos CD8+ do grupo A versus casos CD4+ do grupo B) devido ao $\mathrm{n}$ insuficiente para análise estatística adequada. 
DISCUSSÃO 


\section{DISCUSSÃO}

Avaliamos os aspectos clinicoepidemiológicos, histopatológicos e imuno-histoquímicos de 36 pacientes diagnosticados com MF portadores de lesões hipocrômicas. Esta é uma importante análise de uma ampla casuística de pacientes desta doença rara realizada com base na população brasileira.

O diagnóstico dos pacientes foi clinicopatológico (quadro clínico e exame histopatológico de lesão concordantes). Dos 36 pacientes, 21 apresentavam somente lesões hipocrômicas, constituindo assim a variante MF hipocromiante (MFh - grupo A). Os demais pacientes (15) que apresentavam outras formas de lesão concomitantes foram classificados como portadores de MF mista (MFm - grupo B). Diferentemente da maioria dos estudos sobre a manifestação hipocromiante da MF, nos quais se optou por avaliar os pacientes portadores de lesões hipocrômicas exclusivas em conjunto com os portadores de outras formas de lesões, concomitantes às lesões hipocrômicas, preferimos fazer esta divisão em dois diferentes grupos, justamente buscando avaliar possíveis diferenças entre eles. ${ }^{19,} 40$ 


\subsection{ASPECTOS SOCIOEPIDEMIOLÓGICOS}

A frequência de pacientes com MF portadores de lesões neoplásicas hipocrômicas num serviço terciário, especializado em linfomas cutâneos, foi de $16 \%$. Esta frequência é inferior às relatadas por investigadores na Ásia (Alsaleh et $\mathrm{al}^{25}$., 2010, Kuwait: 40\%; Tan et $\mathrm{al}^{24}$. , 2006, Cingapura: $36 \%$; Khopkar et $\mathrm{al}^{43}$., 2011, Índia: 30\%), porém superior à descrita na Argentina (Abeldaño et al. ${ }^{76}, 2011: 6 \%$ ). Considerando que a população brasileira é miscigenada, apresentando a contribuição de várias etnias em sua composição, esse resultado de 16\%, intermediário entre o encontrado nos países de população melanodérmica homogênea (Kuwait, Índia) e nos países de população caucasiana homogênea (Argentina), é plausível de ser esperado e portanto, concordante com nossa realidade.

Ao contrário da MF clássica, que é uma doença tipicamente das $5^{\underline{a}}$ e $6^{\underline{a}}$ décadas de vida, os pacientes portadores de lesões hipocrômicas desenvolveram a doença e tiveram seus diagnósticos em idades mais precoces. ${ }^{3,24}$ A mediana das idades destes pacientes (grupo A: 40 anos e grupo B: 47 anos) foi inferior significantemente em relação à idade dos demais pacientes portadores de outras variantes de MF/SS do ambulatório de origem $(p<0,001)$. Os pacientes portadores de lesões hipocrômicas apresentaram as primeiras lesões em idades muito inferiores, entre as $2^{\mathrm{a}} \mathrm{e}$ $3^{\text {a }}$ décadas: quando comparados os dois grupos $(\mathrm{A}$ e $\mathrm{B})$ entre si, a idade de 
início foi ainda inferior naqueles pacientes portadores exclusivamente de lesões hipocrômicas (A: mediana 25 anos, B: mediana 29 anos, $p<0,05$ ).

A predileção por indivíduos de fototipos mais altos também foi constatada em nossos pacientes. ${ }^{21,} 27$ Houve um claro predomínio de pacientes pardos e negros em ambos os grupos, sem diferença significante. Porém, ao contrário do que foi anteriormente publicado, que indivíduos caucasianos desenvolveriam preferencialmente a forma mista, não verificamos uma frequência aumentada destes no grupo $\mathrm{B} .{ }^{19}$ Ainda tivemos um paciente de origem asiática no grupo $A$.

Embora os estudos que tem por base a população americana descrevam um predomínio do sexo masculino acometido pela MF clássica, a análise de todos os pacientes com MF sem lesões hipocrômicas acompanhados no ambulatório de Oncologia Cutânea - Linfomas Cutâneos do HCFMUSP mostrou acometimento semelhante de ambos os gêneros. ${ }^{2}$ Por outro lado, tantos os pacientes com variante exclusiva hipocromiante, como aqueles com formas mistas apresentaram maior número de mulheres acometidas (15/21 e 9/15, respectivamente), sem diferença estatística entre si, porém significantes em relação àquela população de demais pacientes do ambulatório $(p<0,001)$. Estes dados confirmam o predomínio de lesões hipocrômica de MF no sexo feminino também descrito previamente. ${ }^{34}$

Nossos achados confirmaram assim as características da variante hipocrômica descritas em casuísticas de outros países, como idade de início precoce e o predomínio em indivíduos melanodérmicos. ${ }^{24,}$ 25, 32 Tais 
propriedades foram verificadas em ambos os grupos, ou seja, independentemente da exclusividade das lesões hipocrômicas. Como discordante da literatura, mostramos que indivíduos brancos/ caucasianos não apresentam preferencialmente a forma mista e sim que indivíduos melanodérmicos apresentam mais frequentemente lesões hipocrômicas, sejam elas exclusivas ou concomitantes a outros tipos de lesões. Além disso, também demonstramos a frequência das duas formas (exclusiva e mista) aumentada no sexo feminino.

\section{$5.2 \quad$ ASPECTOS CLÍNICOS}

Uma observação que contrasta com o que usualmente é descrito nos pacientes com outras formas da MF é a distribuição das lesões no tegumento. Ao invés de lesões concentradas nas regiões das cinturas escapular e pélvica (áreas duplamente cobertas por vestuário) encontramos uma frequência aumentada do acometimento dos membros superiores, inclusive com lesões em áreas fotoexpostas, como terço distal dos braços e antebraços nos pacientes do grupo $\mathrm{A}(p=0,03)$.

O tempo entre início da doença e o diagnóstico foi longo nos dois grupos (medianas de 4 e 5 anos, para grupos A e B respectivamente). Muitos apresentavam história prévia de acompanhamento em outros 
serviços, sem o correto diagnóstico, tendo sido encaminhados ao HCFMUSP para elucidação após insucesso terapêutico ou mesmo por procura espontânea dos pacientes. Estes dados servem de alerta para o provável desconhecimento da forma hipocromiante da MF. São exemplos deste desconhecimento duas pacientes (uma de cada grupo) que apresentavam história de tratamento prévio para hanseníase. Assim, indagamos se as pacientes realmente tiveram hanseníase ou já apresentavam quadro de MF e receberam diagnóstico incorreto daquela doença. Um ponto a favor da última hipótese é que estas pacientes não apresentavam sequelas neurológicas quando avaliadas no ambulatório do HC. Khopkar et al descreveram fato semelhante na Índia: de 15 pacientes com MF hipocromiante , 10 haviam recebido o diagnóstico inicial diferencial de hanseníase e 3 foram tratados com poliquimioterapia. ${ }^{43}$

O bom prognóstico desta variante pode ser aferido pelo estadiamento e pelo tempo de história de doença. Nos dois grupos a maioria dos pacientes apresentava-se em estádios iniciais da MF: 10 pacientes do grupo A e 7 pacientes do grupo B foram classificados no estágio IA (T1NOM0) e 10 pacientes do grupo A e 7 do grupo B no estágio IB. Os dois pacientes, um de cada grupo, classificados no estágio IIA (T2N1M0) são os que possuem maior tempo de história de doença. Aliás, o tempo médio de doença foi longo, sendo maior no grupo B (A: mediana de 8 anos, B: mediana de 13 anos, $p<0,05)$. Assim, temos uma população de pacientes com MF estacionados nos estágios iniciais por muitos anos, sem evolução para quadros mais graves e que mesmo após décadas o estágio máximo que 
atingem é o IIA, caracterizado pela linfadenite dermopática. Tal bom prognóstico observado é corroborado por inúmeros trabalhos, nos quais os pacientes apresentam melhor prognóstico, quando comparados com os pacientes da MF clássica. ${ }^{19,} 20$ Contudo, os autores dos mesmos trabalhos relatam óbitos de pacientes de suas coortes, indicando assim que, apesar do bom prognóstico, o caráter maligno da doença não deve ser subestimado e que um rigoroso acompanhamento clínico dos pacientes com a variante hipocrômica se faz necessário. ${ }^{19,} 20$ Embora constatada após o final do período de observação deste estudo, a evolução da paciente "B2" portadora de uma forma mista de MF (lesões hipocrômicas e eritematosas infiltradas, T2N0M0B0, estádio IB) para o estádio IIB (T3N1M0B0, com população monoclonal detectada em biópsia de pele, linfonodo e sangue periférico) reforçam o aspecto maligno e a obrigatoriedade do acompanhamento clínico contínuo.

Outra observação importante (também coletada após o final da observação deste estudo) foi a evolução do paciente "A1", que de um quadro composto exclusivamente de lesões hipocrômicas passou a apresentar "patches" eritematosos. Assim, é possível a evolução de uma forma hipocrômica exclusiva para uma forma mista, e tal como podemos pressupor a variação de uma forma mista para hipocrômica exclusiva. Desta forma, talvez não se tratem de duas variantes diferentes (forma hipocromiante exclusiva e forma hipocromiante mista) e estáticas, mas sim diferentes espectros de uma mesma doença dinâmica, a variante da MF com lesões hipocrômicas. 
Em relação ao tratamento, obtivemos remissão total em apenas oito pacientes, todos do grupo A (uma mesma paciente tem história de remissão completa com PUVA e UVB-nb); contudo, na última observação apenas três pacientes encontravam-se sem doença ativa, o que mostra o padrão de refratariedade e frequentes recidivas desta variante. ${ }^{19}$ Foram 5 respostas completas com fotoquimioterapia (PUVA) e 4 com fototerapia (UVB-nb), sendo que obtiveram algum período de remissão total 4 dos 6 pacientes brancos e 4 dos 15 pacientes não-brancos (todos do grupo $A, p=0,15$ ). Alguns autores descrevem que a fototerapia (UVB-nb) tem baixas taxas de remissão completa provavelmente devido ao efeito fotoprotetor da melanina nos indivíduos de fototipos mais altos. ${ }^{27,40,71}$ Apesar desta visível diferença, seja remissão completa verificada somente no grupo A, seja a aparente melhor resposta obtida nos pacientes de cor da pele branca (sem significância), diversos fatores nos impedem de obter conclusões confiáveis sobre a efetividade do tratamento e sua relação com a forma clínica da MF. Motivos sociais e infraestruturais contribuem para uma fototerapia inadequada: sessões com frequência insuficiente (semanais a quinzenais), faltas constantes, abandonos do tratamento, suspensões temporárias do tratamento por quebra e falta de manutenção do equipamento são alguns fatores que podemos enumerar. Deste modo, apenas um estudo controlado, com uma monitoria rigorosa e exclusão de fatores externos poderia gerar dados que nos permitissem inferir sobre o melhor tratamento para este subtipo da MF. 


\subsection{ASPECTOS MICROMORFOLÓGICOS}

O exame histológico confirmou alguns achados já descritos como característicos das lesões hipocrômicas, como epidermotropismo em todos os casos, sem espongiose significativa, e a presença de linfócitos pequenos a médios circundados por halos. ${ }^{35}$ Microabscessos de Pautrier foram identificados mais comumente nas lesões dos pacientes do grupo $A$ que 0 descrito na literatura para as lesões da MF clássica. ${ }^{77} \mathrm{Em}$ relação aos achados histológicos da derme, as lesões hipocrômicas apresentaram infiltrado linfomonocitário menos intenso que as lesões não-hipocrômicas, de disposição principalmente perivascular.

Porém, de modo geral, os aspectos micromorfológicos estiveram de acordo com o que se espera observar no diagnóstico da MF. Não pudemos definir nenhum critério, ou um conjunto deles, capazes de diferenciá-los da forma clássica deste linfoma cutâneo. ${ }^{77}$ Assim, deve-se buscar no exame histológico de uma lesão hipocrômica de MF os mesmos dados e informações que seriam esperados para uma lesão da MF clássica. 


\subsection{ASPECTOS FENOTÍPICOS E MECANISMOS PATOGENÉTICOS}

\section{DA HIPOCROMIA}

Quando tomamos o vitiligo como exemplo para estudar o mecanismo fisiopatogênico da hipocromia da MFh, devemos considerar as diferentes teorias já propostas para justificar a disfunção e/ou degeneração melanocítica naquela doença:

1. Mecanismo autoimune, através de anticorpos ou células $T$ citotóxicas contra o melanócito ou o melanossomo, que levariam a destruição ou apoptose do melanócito; ${ }^{78}$

2. Mecanismo autocitotóxico, no qual há produção aumentada de superóxidos, tóxicos para o melanócito; ${ }^{79}$;

3. Alteração dos fatores produzidos pelos queratinócitos adjacentes ou de seus receptores no melanócito, que seriam essenciais para a função e sobrevida do melanócito; ${ }^{57}$

4. Combinação variável destes três padrões descritos. ${ }^{61}$

Tal como no vitiligo, é descrito o predomínio de células T CD8+ na MFh. ${ }^{22,47}$ Seriam estas as células que apresentariam ação citotóxica sobre o melanócito, inicialmente acarretando deterioração da função melanocítica, com prejuízo da melanogênese e da sobrevida desta célula, culminando com a perda progressiva até total da pigmentação cutânea. 
Observou-se um maior número de casos cujo infiltrado epidermotrópico era composto predominantemente por células CD8+ nas lesões dos pacientes do grupo $A$ que nas lesões hipocrômicas dos pacientes do grupo $B$ (16/20 VS. 3/14, $p=0,001)$. Contudo, linfócitos CD8+ foram identificados em todos os casos, mesmo naqueles com franco acometimento por células CD4+. Assim, linfócitos CD8+ neoplásicos e não-neoplásicos poderiam exercer ação citotóxica sobre os melanócitos e seriam capazes de inibi-los, ou mesmo destruí-los, levando a formação de lesões hipocrômicas ou acrômicas.

Dentre as ações da célula T CD8+ sobre o melanócito, autores já supuseram que elas poderiam justamente englobar a redução da expressão de diversas moléculas, como o CD117 e o MITF. ${ }^{22,61}$ Sendo o MITF um fator de transcrição responsável não só por controlar a produção de melanina, mas também essencial para a sobrevida do melanócito (por sua ação regulatória sobre genes apoptóticos, como o Bcl2) e o CD117 seu modulador (por meio da sinalização após ativação pelo SCF), fica evidente o potencial dano para o melanócito se estas moléculas sofrerem prejuízos na sua expressão. A associação da diminuição da expressão de CD117 à diminuição da expressão do MITF na lesão do vitiligo já foi apresentada como um fator altamente predisponente à apoptose do melanócito. ${ }^{61}$.

Se considerarmos apenas os resultados obtidos com os pacientes do grupo A (variante hipocromiante pura), conseguimos não só repetir os resultados de Singh et al. ${ }^{22}$, ao demonstrarmos diminuição do número de melanócitos (Melan-A e tirosinase) e da expressão do CD117 na lesão 
hipocrômica, como validamos estatisticamente este resultado e ampliamos o conhecimento, ao também revelarmos redução da expressão do MITF, de modo semelhante ao que acontece no vitiligo.$^{61}$ Deste modo, vitiligo e MFh compartilham mecanismos citotóxicos semelhantes de destruição melanocítica. A diferença entre eles se daria pela intensidade desta resposta: enquanto no vitiligo temos uma ação citotóxica cujo alvo principal é o melanócito, na MF hipocromiante a destruição do melanócito é um processo secundário à resposta citotóxica desencadeada pela neoplasia.

A relação das citocinas produzida pelos queratinócitos dentro do microambiente da unidade epidérmica é controversa na fisiopatogênese do vitiligo. Lee et al. ${ }^{80}$ descreveram a expressão reduzida de fatores queratinocíticos, como o SCF e o bFGF nas lesões de vitiligo, podendo determinar a apoptose dos melanócitos . Já Kitamura et al. ${ }^{61}$ encontraram expressão aumentada dos fatores SCF e ET-1 na lesão de vitiligo, sugerindo não haver dano da produção queratinocítica de citocinas melanogênicas. Novamente, quando consideramos apenas nossos casos de MFh (grupo A), descrevemos uma alteração significativa do padrão de expressão desta citocina. Além da presença irregular ao longo da epiderme, o que mais se destaca é a sua ausência nas camadas mais inferiores da epiderme, justamente onde se localiza o melanócito. Até o presente momento não há relato na literatura de estudo sobre a relação deste fator com a hipocromia das lesões de MF. Assim, nosso trabalho é o primeiro a descrever um possível desbalanço do SCF dos queratinócitos na fisiopatogênese da MFh, 
tal como Seif El Nasr et al. ${ }^{69}$ já demonstraram em relação ao TNF- $\alpha$ e o bFGF.

Em suma, podemos concluir que, na patogênese da variante hipocromiante da MF, temos uma combinação de mecanismos determinando a hipocromia da lesão. Nas lesões cujo imunofenótipo do infiltrado neoplásico é CD8+ poderíamos considerar esta infiltração como a responsável principal pela ação citotóxica sobre os melanócitos; nas lesões nas quais predominam as células T CD4+, poderíamos supor como provável mecanismo a inibição da função parácrina dos queratinócitos tanto pelas linfocinas produzidas pelas células neoplásicas, além da própria ação dos linfócitos CD8+ reativos. Contudo, o mais adequado é considerar a combinação destes dois mecanismos, além de outros já ou ainda não descritos, como determinantes da despigmentação cutânea nas lesões. 0 TNF- $\alpha$, por exemplo, é uma citocina com ação inibitória sobre a melanogenênese; esta citocina está mais relacionada à imunidade inata e ao padrão de resposta Th1, e que é justamente este último padrão que garante melhor prognóstico na MF, sem evolução para estádios avançados (o que está de acordo com o quadro clínico de lenta progressão da MFh), ${ }^{68,69}$

Se por um lado nossos resultados permitiram algumas conclusões a respeito da MF constituída exclusivamente por lesões hipocrômicas, por outro não encontramos resultados consistentes para responder as lesões hipocrômicas dos pacientes portadores de formas mistas da MF. Não houve concordância imunofenotípica entre as lesões hipocrômica/não-hipocrômica de um mesmo paciente em $28 \%$ dos casos (4/14). Não obtivemos resultados 
significantes com a avaliação imuno-histoquímica dos melanócitos (exceto o número de melanócitos marcados pelo Melan-A). Em relação à expressão do SCF pelos queratinócitos, as lesões não-hipocrômicas apresentaram menor intensidade da expressão nas camadas inferiores que as lesões hipocrômicas. A resposta para estes achados inconclusivos talvez esteja na própria natureza desta variante de MF: a presença de formas mistas de lesões. Sendo uma única doença em um mesmo paciente, mesmo diferentes morfologicamente, as lesões comportariam os mesmos mecanismos básicos, uma vez que se admite que o infiltrado neoplásico seja idêntico. Detalhes, como a expressão aumentada de citocinas, ou a inibição de algum fator, garantiriam a expressão de uma forma, e não de outra. Como exemplo, podemos citar o padrão irregular de expressão do SCF, observado nas lesões hipocrômicas dos pacientes com MFh; nos pacientes com MFm, as lesões hipocrômicas não apresentaram esta alteração com a mesma frequência, além de encontrarmos também esta irregularidade nas lesões não-hipocrômicas. Assim, certamente temos os mesmos mecanismos patogenéticos da MFh atuando na lesão hipocrômica (e mesmo na nãohipocrômica) do paciente com MFm, porém temos a presença de outros fatores colaborando para ou interferindo no resultado final, que é a manifestação morfológica da lesão. Outra justificativa seria o predomínio das lesões poiquilodérmicas como lesões não-hipocrômicas concomitantes dos pacientes com formas mistas; estas lesões apresentam também alterações da pigmentação e autores têm descrito seu imunofenótipo tipicamente CD8+. ${ }^{81}$ É possível que nessas lesões poiquilodérmicas ocorra também 
destruição melanocítica, que justificaria o derrame pigmentar; esta destruição melanocítica poderia ser ocasionada pelos mesmos mecanismos fisiopatogênicos da MFh.

A discordância imunofenotípica observada em alguns pacientes com forma mista (lesão hipocrômica/ lesão não-hipocrômica) poderia ser respondida através da pesquisa do rearranjo gênico do TCR: esta análise permitiria identificar o rearranjo gênico monoclonal na população de células ou T CD4+ ou T CD8+, obtida por microdissecção epidérmica, apontando assim o adequado imunofenótipo (técnica esta não disponível durante este estudo).

A raridade da MFh impediu a demonstração da existência de mecanismos fisiopatogênicos dependentes do imunofenótipo da neoplasia (CD4+ ou CD8+), dado o número insuficiente de casos.

O imunofenótipo CD8+ ainda pode estar associado a linfomas epidermotrópicos cutâneos agressivos, caracterizados por lesões ulceradas e disseminação extranodal. ${ }^{82}$. Agnarsson et al. $^{83}$ descreveram nove pacientes portadores de LCCT com imunofenótipo CD8+: cinco pacientes, cujo infiltrado neoplásico era CD7+, tinham doença agressiva, enquanto que os demais, de infiltrado CD7-, apresentavam doença de curso crônico. Essa perda da expressão de CD7 pelos linfócitos epidérmicos também foi demonstrada nos pacientes avaliados dos grupos A e B. Embora a MF clássica também tenha por característica a perda de expressão do CD7, a perda foi mais significativa nos pacientes portadores de lesões hipocrômicas. 
Assim, a perda deste marcador também poderia ser um dado a ser pesquisado como fator prognóstico nas MF de manifestação cutânea hipocromiante.

Assim, a hipocromia pode ser interpretada como o resultado de uma resposta imune protetora, que através de células neoplásicas ou reativas $\mathrm{T}$ CD8+ (principalmente as células CD7-), está associada a doença indolente, de bom prognóstico, impedindo-se ou retardando-se a transformação para resposta Th2 e evolução da neoplasia. 


\section{CONCLUSÕES}




\section{CONCLUSÕES}

Em relação aos questionamentos levantados nos objetivos deste estudo:

1. De forma semelhante ao que acontece no vitiligo, diferentes mecanismos, como ação celular citotóxica de células CD8+ e a alteração do microambiente da unidade epidérmica, em colaboração, culminam para com a hipocromia das lesões da MFh.

2. Os resultados descritos foram obtidos principalmente a partir da avaliação dos pacientes com MF exclusivamente composta por lesões hipocrômicas. Não foi possível a avaliação dos mecanismos segundo o imunofenótipo do infiltrado linfocitário (CD4+ ou CD8+) devido ao número insuficiente de casos para validação estatística. Não houve diferenças dos achados patogenéticos das lesões hipocrômicas dos pacientes com formas exclusivas versus mistas.

3. Mostrou-se que a variante hipocrômica, embora rara, é responsável por uma parte considerável e não-negligenciável 
de casos de MF no Brasil. Sua frequência foi intermediária entre a descrita em países de populações homogeneamente melanodérmica e a descrita em países de população homogeneamente caucasiana.

4. Demonstrou-se que, independentemente do quadro clínico (lesões hipocrômicas exclusivas ou concomitantes a outras formas de lesões), os achados histopatológicos não foram diferentes dos observados nas lesões nãohipocrômicas da MF; houve comprometimento de uma população de pacientes mais jovens que a usualmente acometida pela MF clássica, com predomínio de indivíduos melanodérmicos, gênero feminino, que evoluíam lentamente por muitos anos, sem atingir os estágios avançados da doença. Assim, a presença de lesões hipocrômicas pode ser considerada um marcador de bom prognóstico na MF. A exclusividade de lesões hipocrômicas pode ser interpretada como um polo da doença, associada a um franco imunofenótipo CD8+; já a forma mista apresenta mais comumente o imunofenótipo CD4+. 
ANEXOS 


\section{ANEXOS}

\section{ANEXO A}

Dados clinicoepidemiológicos dos pacientes do grupo $\mathbf{C}$ (idade ${ }^{1}$, idade de início, idade ao diagnóstico, cor, sexo, estadiamento da doença e localização das lesões) - Ambulatório de Oncologia Cutânea - Linfomas Cutâneos da Divisão de Clínica do HC-FMUSP - fev 2009 a out 2011

\begin{tabular}{|c|c|c|c|c|c|c|c|}
\hline PACIENTE & IDADE & $\begin{array}{l}\text { IDADE } \\
\text { INÍCIO } \\
\text { (ANOS) }\end{array}$ & $\begin{array}{c}\text { IDADE AO } \\
\text { DIAGNÓSTICO } \\
\text { (ANOS) }\end{array}$ & COR & SEXO $^{2}$ & ESTADIAMENTO $^{3}$ & $\begin{array}{l}\text { LOCALIZAÇÃO } \\
\text { DAS LESÕES }^{4}\end{array}$ \\
\hline C1 & 54 & 33 & 52 & Parda & $\mathrm{F}$ & T2NOMOBO & MMII/ Tronco \\
\hline C2 & 31 & 14 & 26 & Branca & $\mathrm{F}$ & T2N0M0B0 & Tronco/ MMSS \\
\hline C3 & 51 & 24 & 42 & Branca & M & T1N0M0B0 & Tronco/ MMII \\
\hline C4 & 60 & 22 & 54 & Branca & $M$ & T1N0M0B0 & Tronco \\
\hline C5 & 75 & 72 & 73 & Branca & M & T1N0M0B0 & MMSS/ MMII \\
\hline C6 & 64 & 18 & 46 & Branca & $\mathrm{F}$ & T1N0M0B0 & MMII/ Tronco \\
\hline C7 & 71 & 68 & 69 & Branca & $\mathrm{F}$ & T1N0M0B0 & MMII \\
\hline C8 & 68 & 22 & 68 & Branca & $M$ & T1N0M0B0 & Tronco \\
\hline
\end{tabular}

1. Idade à conclusão do período de observação (outubro de 2011).

2. Sexo M: masculino, sexo F: feminino.

3. Estadiamento sistema TNMB.

4. MMII: membros inferiores, MMSS: membros superiores. 
ANEXO B

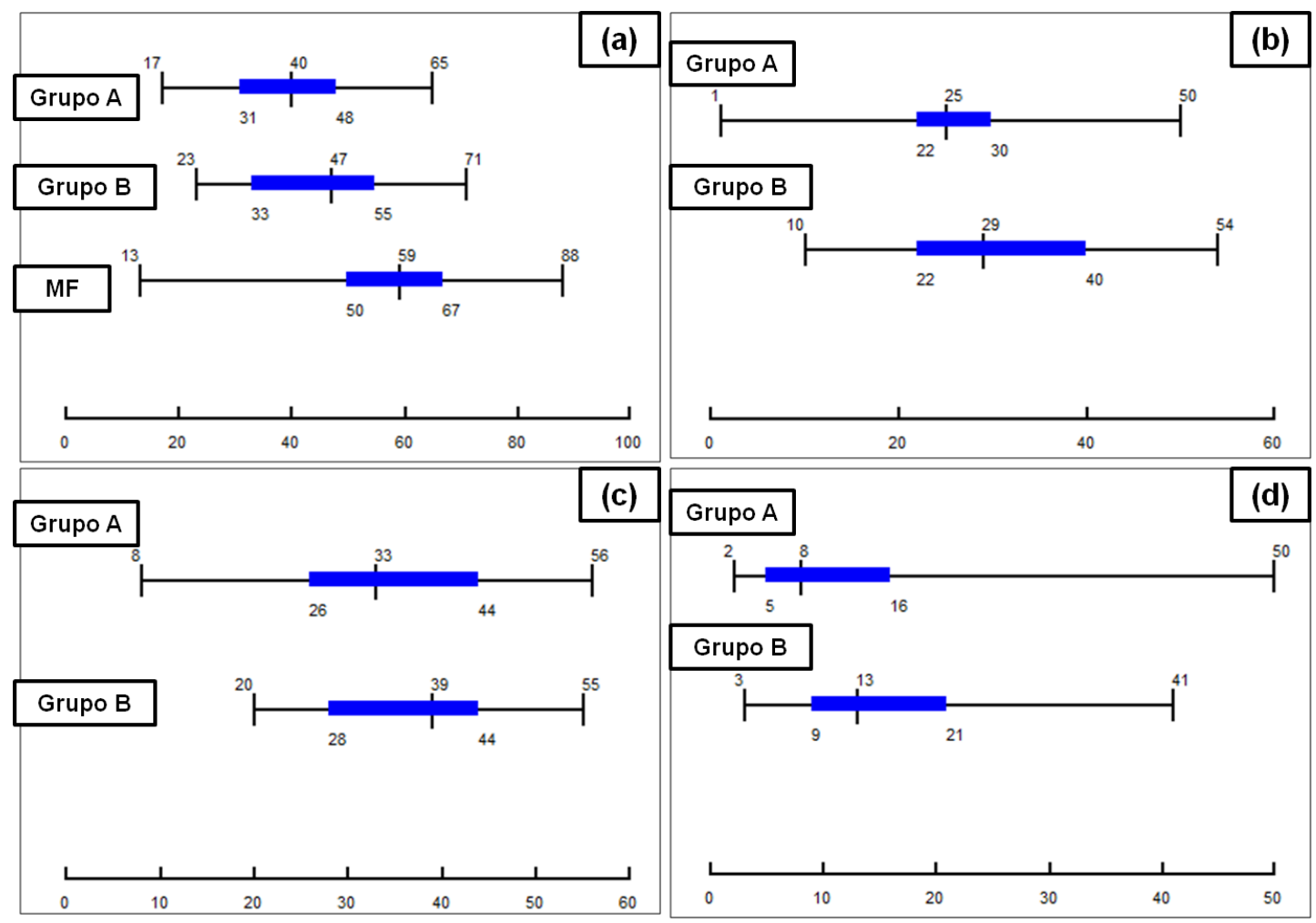

Apresentação da análise dos dados clinicoepidemiológicos dos pacientes dos grupos $A$ ( $1^{\circ}$ barra), B ( $2^{\circ}$ barra) e dos pacientes com MF sem lesões hipocrômicas do ambulatório de Oncologia Cutânea - Linfomas Cutâneos do HCFMUSP (3ํㅡㅁ barra). (a) mostra a idade dos pacientes na última avaliação (out 2001); (b) apresenta a idade de início da doença; (c) traz a idade ao diagnóstico e (d), o tempo de doença 
ANEXO C

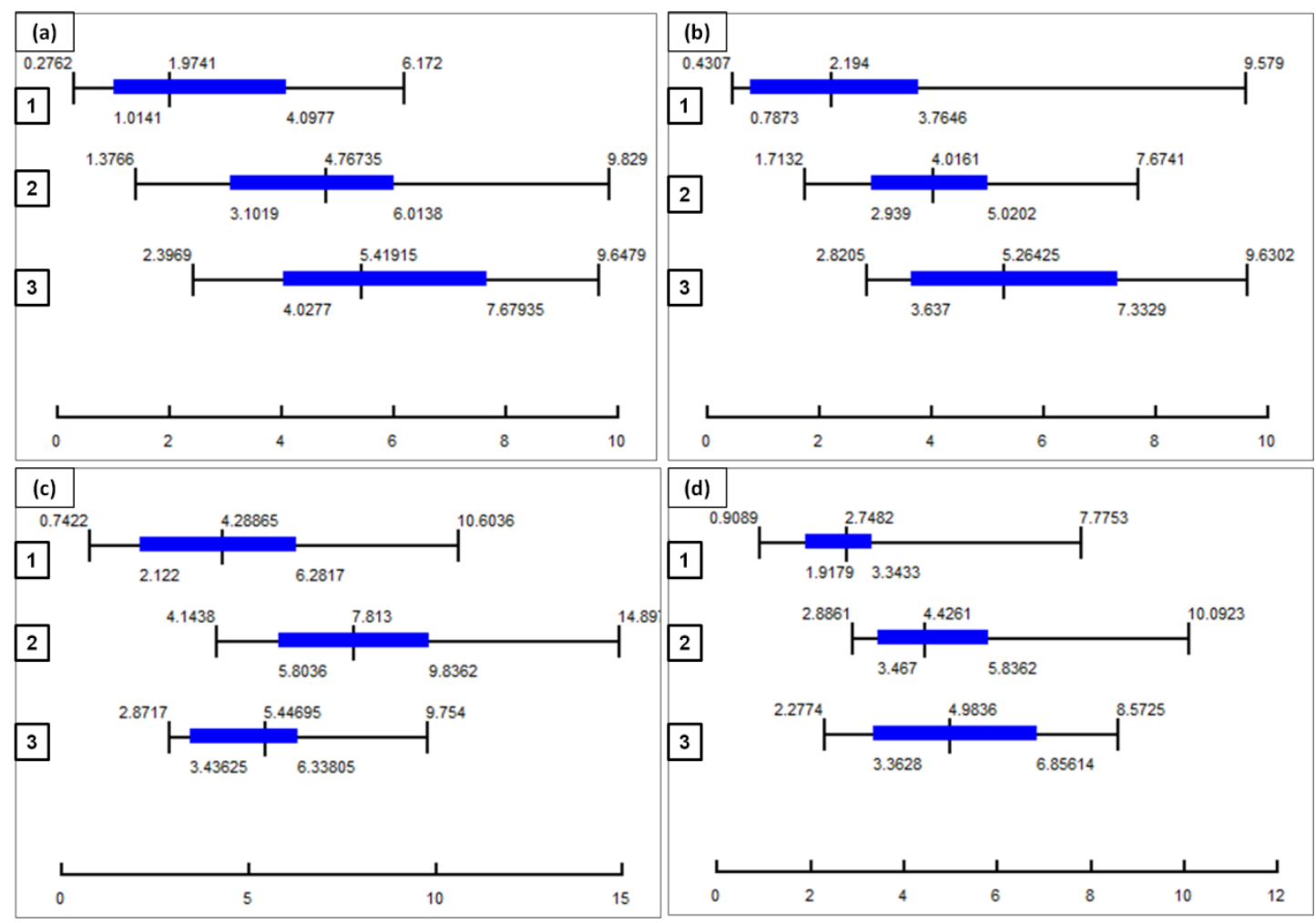

Apresentação dos resultados da análise da imunomarcação dos melanócitos na forma de boxplot (grupos $\mathrm{A}$ e $\mathrm{C}$ ). Estes gráficos resumem os dados mostrados na tabela 10, sendo que a barra "1" representa a lesão hipocrômica dos pacientes do grupo A, a barra "2" representa a amostra de pele normal dos mesmos pacientes do grupo A e a barra "3" refere-se à lesão não-hipocrômica dos pacientes do grupo C. Os imunomarcadores apresentados são: (a) Melan-A; (b) tirosinase; (c) CD117 e (d) MITF 
ANEXO D

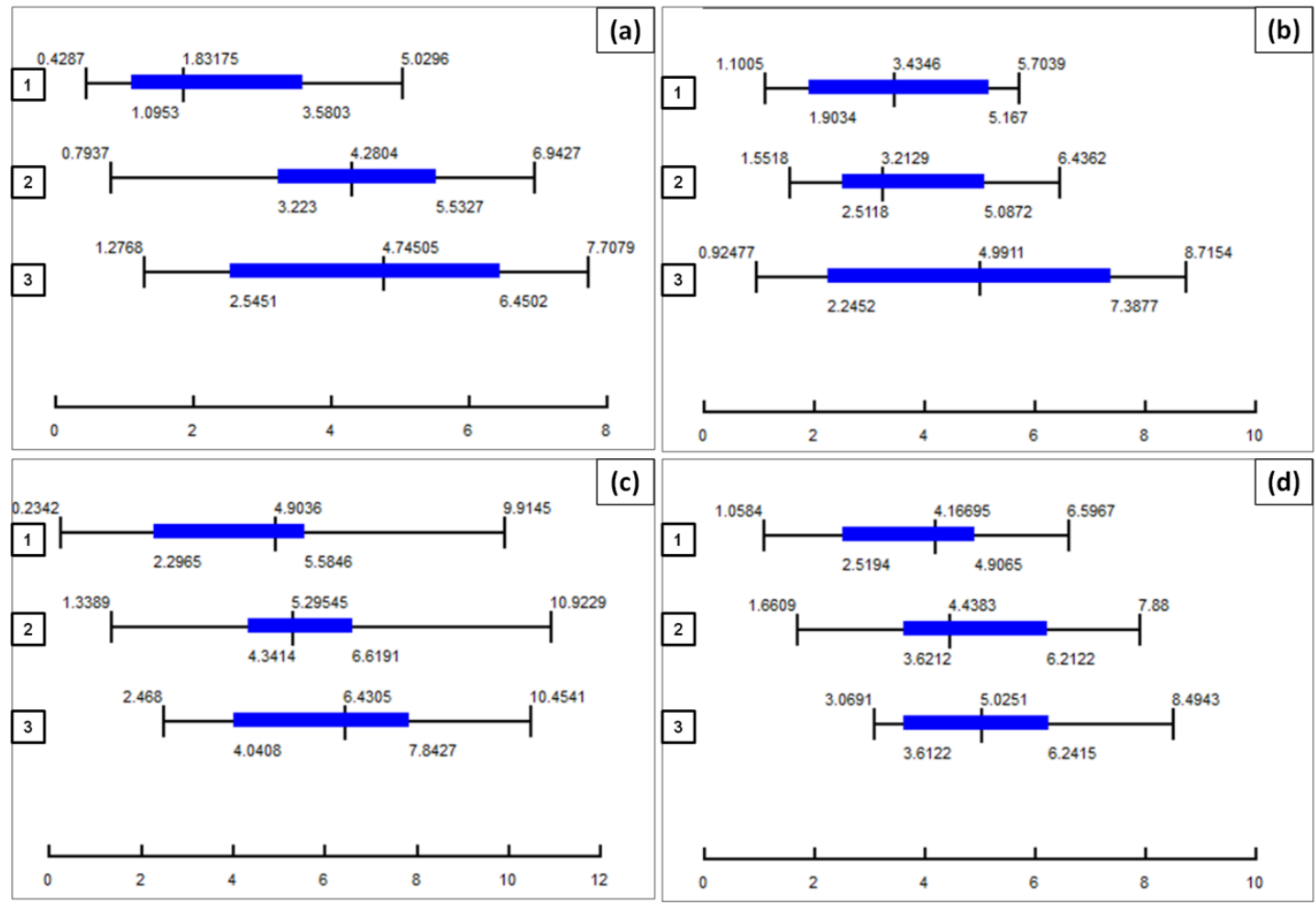

Apresentação dos resultados da análise da imunomarcação dos melanócitos na forma de boxplot (grupo B). Estes gráficos resumem os dados mostrados na tabela 11, sendo que a barra "1" representa a lesão hipocrômica, a barra "2" representa a amostra de pele normal e barra "3" refere-se à lesão nãohipocrômica, todas provenientes dos pacientes do grupo B. Os imunomarcadores apresentados são: (a) Melan-A; (b) tirosinase; (c) CD117 e (d) MITF 
ANEXO E

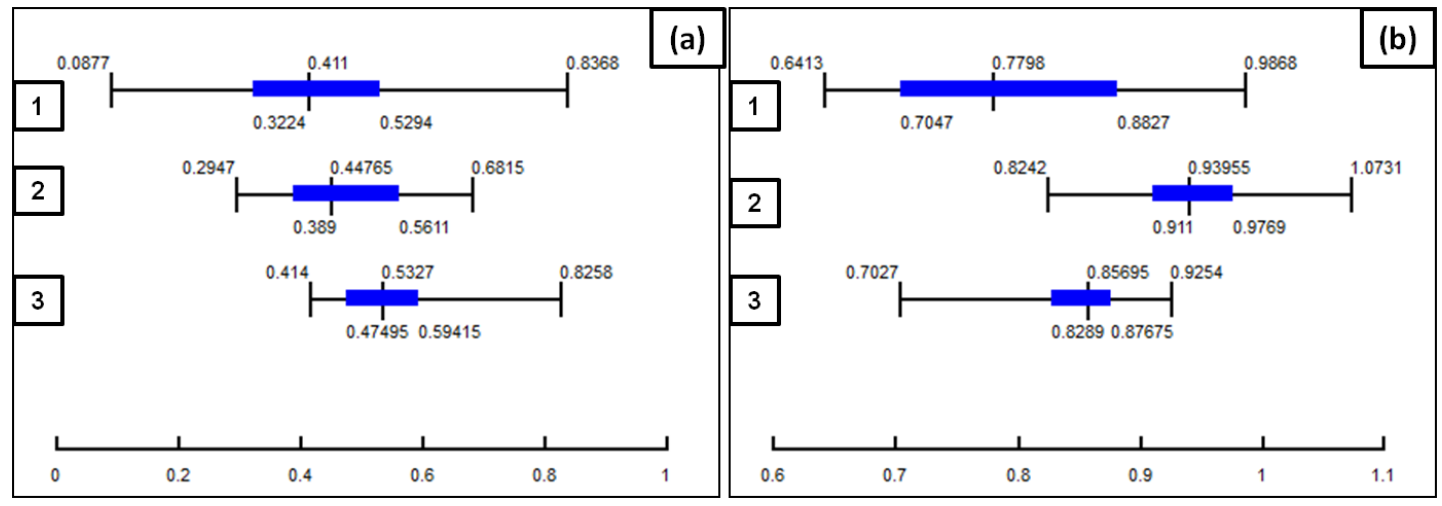

Apresentação dos resultados da análise da imunomarcação do SCF epidérmico na forma de boxplot (grupos $\mathrm{A}$ e C). Estes gráficos resumem os dados mostrados na tabela 12, sendo que a barra "1" representa a lesão hipocrômica dos pacientes do grupo A, a barra "2" representa a amostra de pele normal dos mesmos pacientes do grupo A e barra " 3 " refere-se à lesão não-hipocrômica dos pacientes do grupo C. Os gráficos referem-se à: (a) área marcada (razão dos valores obtidos nas camadas inferiores pelo valor da epiderme total) e (b) intensidade da marcação (razão dos valores obtidos nas camadas inferiores pelo valor da epiderme total)

ANEXO F
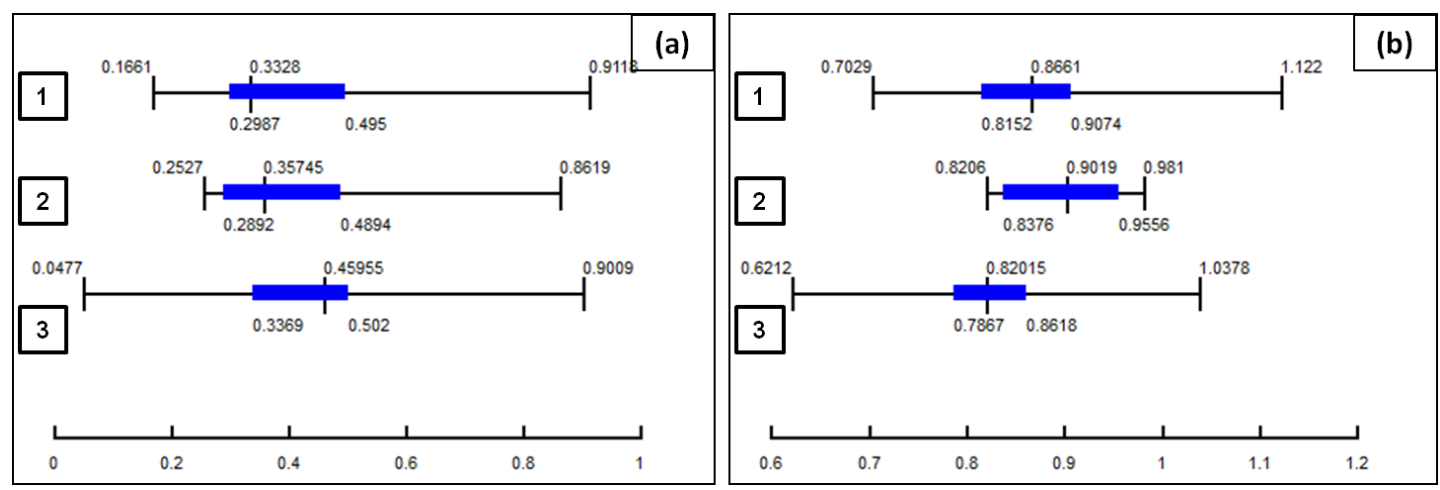

Apresentação dos resultados da análise da imunomarcação do SCF epidérmico na forma de boxplot (grupo B). Estes gráficos resumem os dados mostrados na tabela 13, sendo que a barra "1" representa a lesão hipocrômica, a barra "2" representa a amostra de pele normal e barra "3" refere-se à lesão não-hipocrômica, todas provenientes dos pacientes do grupo B. Os gráficos referem-se à: (a) área marcada (razão dos valores obtidos nas camadas inferiores pelo valor da epiderme total) e (b) intensidade da marcação (razão dos valores obtidos nas camadas inferiores pelo valor da epiderme total) 
REFERÊNCIAS 


\section{REFERÊNCIAS}

1. Whitttaker SJ, Mackie RM. Cutaneous lymphomas and lymphocitic infiltrates In: Burns T, Breathnach S, Cox N, Griffiths C, editors. Rook's textbook of dermatology. $7^{\text {th }}$ ed. Blackwell Publishing, Oxford, UK, 2004.p.54.1-54.53

2. Criscione VD, Weinstock MA. Incidence of cutaneous T-cell lymphoma in the United States, 1973-2002. Arch Dermatol 2007:143:854-9.

3. Keehn CA, Belongie IP, Shistik G, Fenske NA, Glass F. The diagnosis, staging, and treatment options for mycosis fungoides. Cancer Control 2007;14:102-11.

4. Ackerman AB, Flaxman BA. Granulomatous mycosis fungoides. Br J Dermatol 1970;82:397-401.

5. Ackerman AB, Miller RC, Shapiro L. Pustular mycosis fungoides. Arch Dermatol 1966;93:221-5.

6. Gordon H. Mycosis fungoides. Br J Dermatol 1950;62:177-82.

7. Price NM, Fuks ZY, Hoffman TE. Hyperkeratotic and verrucous features of mycosis fungoides. Arch Dermatol 1977;113:57-60.

8. Roegnigk HH, Castrovinci AJ. Mycosis fungoides bullosa. Arch Dermatol 1971;104:402-6. 
9. Pujol RM, Gallardo F, Llistosella E, Blanco A, Bernadó L, Bordes $\mathrm{R}$ et al. Invisible mycosis fungoides: a diagnostic challenge. J Am Acad Dermatol 2002;47:S168-71.

10. Smith NP, Samman PD. Mycosis fungoides presenting with areas of cutaneous hypopigmentation. Clin Exp Dermatol 1978;3:213-6.

11. Ryan EA, Sanderson KV, Bartak P, Samman PD. Can mycosis fungoides begin in the epidermis? A hypothesis. Br J Dermatol 1973;419-29.

12. Zackeim HS, McCalmont TH. Mycosis fungoides: the great imitator. J Am Acad Dermatol 2002;47:914-8.

13. Choe YB, Park KC, Cho KH. A case of hypopigmented mycosis fungoides. J Dermatol 2000;27:543-6.

14. Duquia RP, Souza PRM, Gervini RL, Schwartz J, Prochnau A, Almeida Junior HL. Micose fungóide com 20 anos de evolução. An Bras Dermatol 2005;80:189-91

15. Silva ACLG, Rito RA, Pires MC, Valente NYS, Sittart JAS. Micose fungóide hipocrômica. Rev Bras Clin Ter 1997;23:192-4.

16. Bittencourt AL, Dias NFC, Souza LRG, Carvalho WA. Micose fungoide em adolescente associada a mucinose folicular. Apresentação de um caso. Med Cut ILA 1990;18:167-9.

17. Neuhaus IM, Ramos-Caro FA, Hassanein AM. Hypopigmented mycosis fungoides in childhood and adolescense. Pediatr Dermatol 2000; 17:403-6.

18. Özcan D, Seçkin D, Özdemir BH. Hypopigmented macules in na adult male patient. Clin Exp Dermatol 2008;33:667-8. 
19. Ardigó M, Borroni G, Muscardin L, Kerl H, Cerroni L. Hypopigmented mycosis fungoides in caucasian patients: a clinicopathology study of 7 cases. J Am Acad Dermatol 2003;49:264-70.

20. Stone ML, Styles AR, Cockerell CJ, Pandya AG. Hypopigmented mycosis fungoides: a report of 7 cases and review of the literature. Cutis 2001;67:133-8.

21. Lambroza E, Cohen SR, Phelps R, Lebwohl M, Braverman IM, DiCostanzo D. Hypopigmented variant of mycosis fungoides: demography, histopathology, and treatment of seven cases. J Am Acad Dermatol $1995 ; 32: 987-93$.

22. Singh ZN, Tretiakova MS, Shea CR, Petronic-Rosic VM. Decreased CD117 expression in hypopigmented mycosis fungoides correlates with hypomelanosis:lessons learned from vitiligo. Mod Pathol 2006;19:1255-60.

23. Pope E, Weitzman S, Ngan B, Walsh S, Morel K, Williams J et al. Mycosis fungoides in the pediatric population: report from an international Childhood Registry of Cutaneous Lymphoma. J Cutan Med Surg. 2010; 14:16.

24. Tan EST, Tang MBY, Tan SH. Retrospective 5-year review of 131 patients with mycosis fungoides and Sézary syndrome seen at the National Skin Centre, Singapore. Australas J Dermatol 2006;47:248-52.

25. Alsaleh QA, Nanda A, Al-Ajmi H, Al-Sabah H, Elkashlan M, AlShemmari $\mathrm{S}$ et al. Clinicoepidemiological features of mycosis fungoides in Kuwait, 1991-2006. Int J Dermatol 2010; 49:1393-8. 
26. Robert C, Moulonguet I, Baudot N, Flaugeul B, Dubertret L. Hypopigmented mycosis fungoides in a light-skinned woman. $\mathrm{Br} \mathrm{J}$ Dermatol 1998;139:341-3.

27. Akaraphanth R, Douglass MC, Lim HW. Hypopigmented mycosis fungoides: treatment and a 6 1/2 -year follow-up of 9 patients. J Am Acad Dermatol 2000;42:33-9.

28. Halder RM, Ara CJ. Skin cancer and photoaging in ethnic skin. Dermatol Clin 2003;21:725-32.

29. Das JK, Gangopadhyay AK. Mycosis fungoides with unsual vitiligo-like presentation. Indian J Dermatol Venereol Leprol 2004;70:304-6.

30. Hsiao PF, Hsiao $\mathrm{CH}$, Tsai TF, Jee SH. Minimal residual disease in hypopigmented mycosis fungoides. J Am Acad Dermatol 2006;54:S198201.

31. Tan E, Tay YK, Giam YC. Profile and outcome of childhood mycosis fungoides in Singapore. Pediatr Dermatol 2001;17:352-6.

32. AlGhamdi KM, Arafah MM, Al-Mubarak LA, Khachemoune A, Al-Saif FM. Profile of mycosis fungoides in 43 Saudi patients. Ann Saudi Med. 2012;32:283-7.

33. Jang MS, Kang DY, Park JB, Kim ST, Suh KS. Cutaneous Tcell lymphoma in Asians. ISRN Dermatol. 2012;2012:575120. Epub 2012 Jul 15.

34. El Shabrawi-Caelen L, Cerroni L, Medeiros LJ, McCalmont TH. Hypopigmented mycosis fungoides. Frequent expression of a CD8+ T-cell phenotype. Am J Surg Pathol 26;450-7. 
35. Werner B, Brown S, Ackerman AB. Hypopigmented mycosis fungoides is not always mycosis fungoides! Am J Dermatopathol 2005;27:5667.

36. Hsu CK, Hsu MM, Lee JYY. Fusariosis occuring in na ulcerated cutaneous CD8+ T cell lymphoma tumor. Eur J Dermatol 2006;16:297-301.

37. Uhlenhake EE, Mehregan DM. Annular hypopigmented mycosis fungoides: a novel ringed variant. J Cutan Pathol. 2012;39:535-9

38. Hodak E, Phenig E, Amichai B, Feinmesser M, Kuten A, Maron L et al. Unilesional mycosis fungoides. Dermatology 2000;201:300-6.

39. Roupe G. Hypopigmented mycosis fungoides in a child successfully treated with UVA-1 light. Pedriatric Dermatol 2005;22:82.

40. Manzur A, Zaidi STH. Hypopigmented mycosis fungoides in a 10 year-old boy. Dermatol Online J 2006;16:584.

41. Goldberg DJ, Schinella RS, Kechijian P. Hypopigmented mycosis fungoides. Speculations about the mechanism of hypopigmentation. Am J Dermatopathol 1986;8:326-30.

42. Kavala M, Zındancı I, Sudogan S, Can B, Turkoglu Z, Demırkesen C, Kural E. Mycosis fungoides presenting as hypopigmented and pigmented purpura-like lesions: coexistance of two clinical variants. Eur J Dermatol. 2011;21:272-3.

43. Khopkar U, Doshi BR, Dongre AM, Gujral S. A study of clinicopathologic profile of 15 cases of hypopigmented mycosis fungoides. Indian J Dermatol Venereol Leprol. 2011;77:167-73. 
44. El-Darouti MA, Fawzy MM, Hegazy RA, Abdel Hay RM. Hypopigmented parapsoriasis en plaque, a new overlooked member of the parapsoriasis family: A report of 34 patients and a 7 -year experience. $\mathrm{J}$ Am Acad Dermatol. 2012 Mar 27. [Epub ahead of print]

45. Wain EM, Orchard GE, Whittaker SJ, Spittle MF, Russell-Jones R. Outcome in 34 patients with juvenile-onset mycosis fungoides. Cancer 2003;98:2282-90.

46. Olsen EA, Whittaker S, Kim YH, Duvic M, Prince HM, Sanches JA et al. Clinical end points and response criteria in mycosis fungoides and Sézary syndrome: a consensus statement of the International Society for Cutaneous Lymphomas, the United States Cutaneous Lymphoma Consortium, and the Cutaneous Lymphoma Task Force of the European Organisation for Research and Treatment of Cancer. J Clin Oncol. 2011; 29:2598-607.

47. El-Darouti MA, Marzouk AS, Fawzi MM, Abde-Halim MRE, Zayed AA, Leheta TM. Vitiligo vs. Hypopigmented mycosis fungoides (histopathological and immunohistochemical study, univariate analysis). Eur J Dermatol 2006;16:17-22.

48. Volkenandt M, Soyer HP, Cerroni L, Koch OM, Atzpodien JÁ, Kerl H. Molecular detection of clone-specific DNA in hypopigmented lesions of a patient with early evolving mycosis fungoides. $\mathrm{Br} J$ Dermatol 1993;128:423-8. 
49. Di Landro A, Marchesi L, Naldi L, Motta T, Cainelli T. A case of hypopigmented mycosis fungoides in a young Caucasian boy. Pediatr Dermatol 1997;14:449-52.

50. Rosdahl I, Rorsman H. An stimate of the melanocyte mass in humans. J Invest Dermatol 1983; 81:278-81.

51. Raposo G, Marks MS. Melanosomes-dark organelles enlighten endosomal membrane transport. Nat Rev Mol Cell Biol 2007;8:786-97.

52. Schallreuter KU, Kothari S, Chavan B, Spencer JD. Regulation of melanogenesis - controversies and new concepts. Experimental Dermatology 2008; 17:395-404.

53. Simon JD, Peles D, Wakamatsu K, Ito S. Current challenges in understanding melanogenesis: bridging chemistry, biological control, morphology, and function. Pigment Cell Melanoma Res 2009; 22:563-79.

54. Samokhalov A, Hong L, Liu Y, Garguilo J, Nemanich RJ, Edwards GS, Simon JD. Oxidative potencials of human eumelanosomes and pheomelanosomes. Photochem Photobiol 2005; 81:145-8.

55. Kobayashi N, Nakagawa A, Muramatsu T, Yamashina Y, Shirai T, Hashimoto MW et al. Supranuclear melanin caps reduce ultraviolet induced DNA photoproducts in human epidermis. J Invest Dermatol 1998; 110 : 806-10.

56. Hodgkinson CA, Moore KJ, Nakayama A, Steingrimsson E, Copeland NG, Jenkins NA, Arnheiter $H$. Mutations at the mouse microphthalmia locus are associated with defects in a gene encoding a novel basic-helix-loop-helix-zipper protein. Cell 1993; 74: 395-404. 
57. Hughes AE, Newton VE, Liu XZ, Read AP. A gene for Waardenburg syndrome type 2 maps close to the human homologue of the microphthalmia gene at chromosome 3p12-p14.1. Nat Genet 1994; 7: 50912.

58. Cheli Y, Ohanna M, Ballotti R, Bertolotto C. Fifteen-year quest for microphthalmia-associated transcription factor target genes. Pigment Cell Melanoma Res 2009; 23: 27-40.

59. Yamaguchi Y, Hearing VJ. Physiological factors that regulate skin pigmentation. Biofactors 2009 ;35:193-9.

60. Liu JJ, Fisher DE. Lighting a path to pigmentation: mechanisms of MITF induction by UV. Pigment Cell Melanoma Res 2010; 23:741-5.

61. Kitamura R, Tsukamoto K, Harada K, Shimizu A, Shimada S, Kobayashi T, Imokawa G. Mechanisms underlying the dysfunction of melanocytes in vitiligo epidermis: role of SCF/KIT protein interactions and the downstream effector, MITF-M. J Pathol 2004;202:463-75.

62. Ray P, Krishnamoorthy N, Ray A. Emerging functions of c-kit and its ligand stem cell factor in dendritic cells. Cell Cycle 2008; 7:2826-32.

63. Breathnach SM, McKee PH, Smith NP. Hypopigmented mycosis fungoides: report of five cases with ultrastructural observations. $\mathrm{Br} \mathrm{J}$ Dermatol 1982;106:643-9.

64. Goldberg DJ, Schinella RS, Kechijian P. Hypopigmented mycosis fungoides. Speculations about the mechanism of hypopigmentation. Am J Dermatopathol 1986;8:326-30. 
65. Bouloc A, Grange F, Delfau-Larue MH, Dieng MT, Tortel MC, Avril MF et al. Leucoderma associated with flares of erythrodermic cutaneous T-cell lymphomas:four cases. Br J Dermatol 2000;143:832-6.

66. Chuang GS, Wasserman DI, Byers HR, Demierre MF. Hypopigmented T-cell discrasia evolving to hypopigmented mycosis fungoides during etanercept therapy. J Am Acad Dermatol 2008;59:S121-2.

67. Kim EJ, Hess S, Richardson SK, Newton S, Showe LC, Benoit BM et al. Immunopathogenesis and therapy of cutaneous T cell lymphoma. J. Clin. Invest 2005;115:798-812.

68. Moretti S, Spallanzani A, Amato L, Hautmann G, Gallerani I, Fabiani $\mathrm{M}$ et al. New insights into the pathogenesis of vitiligo: imbalance of epidermal cytokines at sites of lesions. Pigment Cell Res 2002; 15: 87-92.

69. Seif El Nasr H, Shaker OG, Fawzi MMT, El-Hanafi G. Basic fibroblast growth factor and tumour necrosis factor alpha in vitiligo and other hypopigmented disorders: suggestive possible therapeutic targets. J Eur Acad Dermatol Venereol. 2011; [Epub ahead of print]

70. Alikhan A, Felsten LM, Daly M and Petronic-Rosic V. Vitiligo: A comprehensive overview. J Am Acad Dermatol 2011;65:473-91.

71. Gathers RC, Scherschun L, Malick F, Fivenson DP, Lim HW. Narrowband UVB phototherapy for early-stage mycosis fungoides. J Am Acad Dermatol. 2002; 47:191-7.

72. Kanokrungsee S, Rajatanavin N, Rutnin S, Vachiramon V. Efficacy of narrowband ultraviolet B twice weekly for hypopigmented mycosis fungoides in Asians. Clin Exp Dermatol. 2012; 37:149-52. 
73. Wongpraparut C, Setabutra P. Phototherapy for hypopigmented mycosis fungoides in Asians. Photodermatol Photoimmunol Photomed. 2012;28:181-6

74. Olsen E, Vonderheid E, Pimpinelli N, Willemze R, Kim $\mathrm{Y}$, Knobler $\mathrm{R}$ et al. Revisions to the staging and classification of mycosis fungoides and Sézary syndrome: a proposal of the International Society for Cutaneous Lymphomas (ISCL) and the cutaneous lymphoma task force of the European Organization of Research and Treatment of Cancer (EORTC). Blood 2007; 110:1713-22.

75. Magro CM, Mihm MC, Crowson AN. Mycosis Fungoides In: Magro CM, Crowson AN, Mihm MC. The Cutaneous Lymphoid Proliferations. John Wiley\& Sons, Hoboken, USA, 2007.p.267-99

76. Abeldaño A, Arias M, Benedetti A, Ochoa K, Maskin M, Pellerano $G$ et al. Unusual variants of mycosis fungoides. Skinmed. 2011;9:218-22.

77. Shapiro PE, Pinto FJ. The histologic spectrum of mycosis fungoides/Sézary syndrome (cutaneous T-cell lymphoma). A review of 222 biopsies, including newly described patterns and the earliest pathologic changes. Am J Surg Pathol. 1994;18:645-67.

78. van den Wijngaard R, Wankowicz-Kalinska A, Pals S, Weening J, Das P. Autoimmune melanocyte destruction in vitiligo. Lab Invest. 2001; $81: 1061-7$.

79. Passi S, Grandinetti M, Maggio F, Stancato A, De Luca C. Epidermal oxidative stress in vitiligo. Pigment Cell Res. 1998; 11:81-5. 
80. Lee AY, Kim NH, Choi WI, Youm YH. Less keratinocyte-derived factors related to more keratinocyte apoptosis in depigmented than normally pigmented suction-blistered epidermis may cause passive melanocyte death in vitiligo. J Invest Dermatol. 2005;124:976-83.

81. Abbott RA, Sahni D, Robson A, Agar N, Whittaker S, Scarisbrick JJ. Poikilodermatous mycosis fungoides: a study of its clinicopathological, immunophenotypic, and prognostic features. J Am Acad Dermatol. 2011;65:313-9.

82. Nofal A, Abdel-Mawla MY, Assaf M, Salah E. Primary cutaneous aggressive epidermotropic CD8+ T-cell lymphoma: proposed diagnostic criteria and therapeutic evaluation. $J$ Am Acad Dermatol. 2012;67:748-59.

83. Agnarsson BA, Vonderheid EC, Kadin ME. CD8+ cutaneous Tcell lymphoma. Am J Dermatopathol. 1991;13:628-9. 